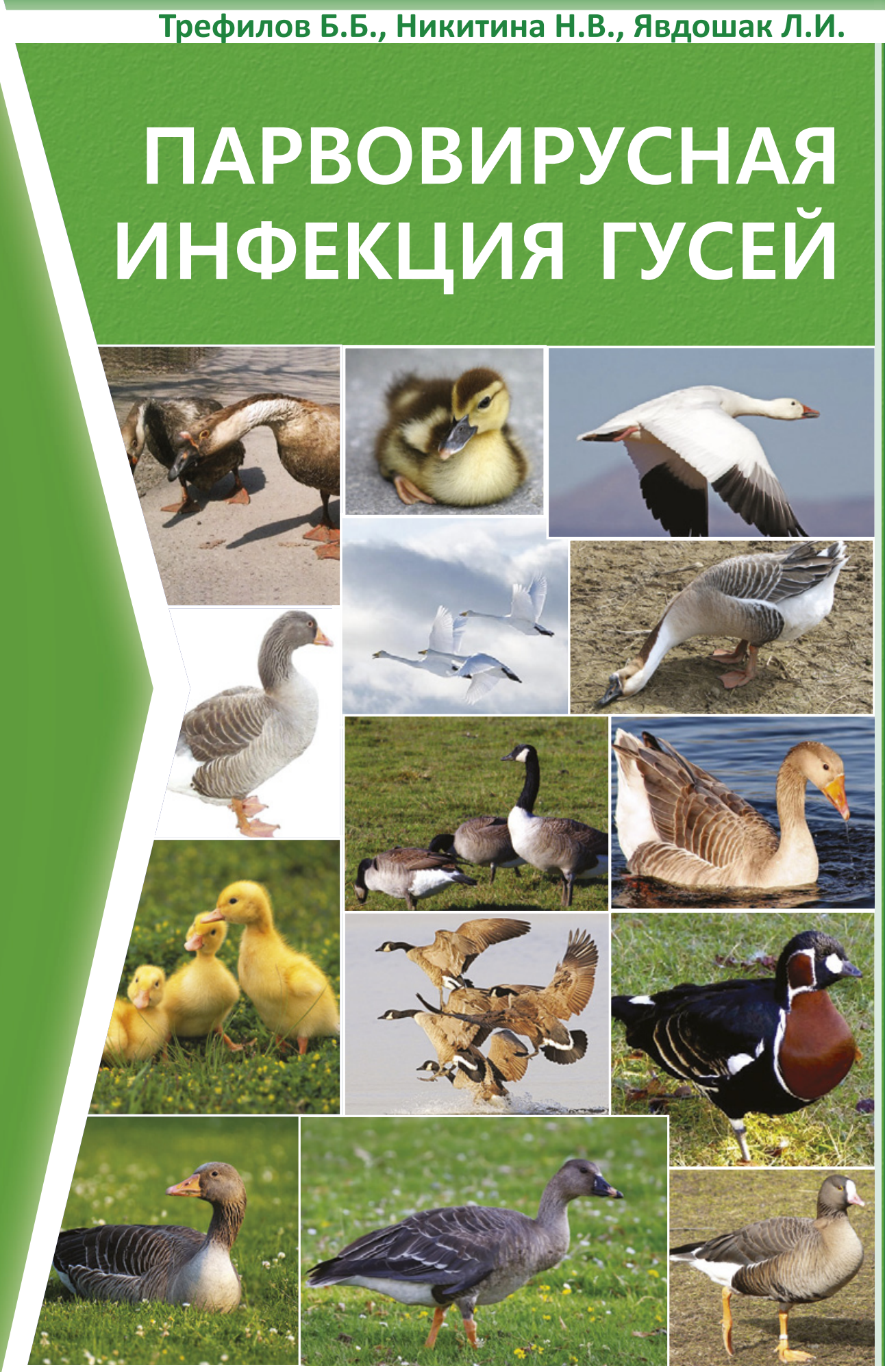


Трефилов Б.Б., Никитина Н.В., Явдошак Л.И.

\section{ПАРВОВИРУСНАЯ ИНФЕКЦИЯ ГУСЕЙ}

Санкт-Петербург - Ломоносов 2013 
Рецензенты: доктор биологических наук, профессор А.А.Сухинин, доктор ветеринарных наук, профессор В.А. Бакулин (ФГОУ ВПО СПбГАВМ, Санкт-Петербург).

Трефилов Б.Б., Никитина Н.В., Явдошак Л.И. Парвовирусная инфекция гусей. Санкт-Петербург : изд-во ООО «РК Агат» : Любавич. - 2013. - 80 стр.

ISBN 978-5-86983-522-2

На основе обобщения литературных данных и результатов многолетних экспериментальных исследований авторов в настоящей монографии изложены современные представления о биологии, патогенных потенциях, этиологической роли широко распространенного парвовируса в инфекционной патологии гусей.

Особое внимание уделено анализу клинико-эпизоотологических особенностей, закономерностей развития и проявления парвовирусной инфекции гусей.

С учетом новейших достижений современной иммунологии и молекулярной биологии подробно освещается возможность применения высокочуствительных специфических методов индикации возбудителя и выявления гуморальных антител у больных и переболевших птиц, а также дается сравнительная оценка их эффективности.

Анализируя проблему парвовирусной инфекции гусей, авторы представили сведения и теоретические основы по ее пассивной и активной специфической профилактике. Показана эффективность аттенуированных вирусвакцин и инактивированных препаратов, а также гипериммунной сыворотки с целью создания эффективной системы мероприятий по борьбе с парвовирусной инфекцией.

Монография предназначена для практических ветеринарных специалистов, научных сотрудников, аспирантов, преподавателей вузов и студентов ветеринарных факультетов.

ISBN 978-5-86983-522-2

(C) гНУ ВНИВИП Россельхозакадемии, 2013

(C) РК «Агат»

(C) Издательство «Любавич», 2013 


\section{ВВЕДЕНИЕ}

В последние годы достигнуты определенные успехи в изучении инфекционных болезней молодняка водоплавающих птиц вирусной и бактериальной природы.

На фоне достижений по изучению этой проблемы особенно явной становится концентрация усилий исследователей по изысканию специфических средств профилактики и эффективных методов защиты молодняка от такой весьма распространенной инфекционной болезни, как парвовирусная инфекция гусей. Нет сомнений, что одной из причин порождающих трудности в борьбе с этой болезнью, является недостаток знаний об ее этиологии, о свойствах возбудителя, методах диагностики и средствах профилактики. В этой связи сохраняется также актуальность разработки таких технологических систем, которые обеспечивали бы получение здорового молодняка с высокой резистентностью.

Возникновение парвовирусной инфекции гусей, тяжесть течения болезни тесно связаны с нарушением санитарно-гигиенического и противоэпизоотического режима, а также технологии кормления.

Решение проблемы борьбы с парвовирусной инфекцией осложняется преимущественно смешанной формой ее течения. Передача вируса происходит трансовариально. Переболевшие гусята и родители длительное время остаются вирусоносителями, отмечается цикличность (2-4 года) в возникновении болезни.

В мировой литературе данная проблема представлена многочисленными публикациями. В последние 20-25 лет XX века и в начале XXI века накоплен огромный материал, как за рубежом, так и в Российской Федерации, что позволило сделать ряд обобщений. К сожалению, многие из этих работ не доступны широкому кругу ветеринарных специалистов, призванных обеспечивать ветеринарное благополучие в промышленном птицеводстве и фермерских хозяйствах.

Предлагаемая вниманию ветеринарных специалистов, преподавателей вузов, молодых ученых и аспирантов информация суммирует научный опыт отечественных и зарубежных исследователей. Изучение парвовирусной инфекции охватывает этиологию, клинико-эпизоотологические особенности, закономерности развития и проявления различных форм болезни, разработку методов и средств диагностики, а также изыскание средств и методов специфической профилактики с целью создания эффективной системы мероприятий по ликвидации болезни, являющейся бичом гусеводства в России.

Затронутые в монографии проблемы имеют выраженную практическую направленность и, несомненно, будут способствовать повышению эффективности борьбы с парвовирусной инфекцией молодняка гусей и мускусных уток. 


\section{Значение и предпосылки}

\section{инновационного развития гусеводства}

Основным документом, определяющим развитие сельского хозяйства Российской Федерации на современном этапе, является Доктрина продовольственной безопасности, утвержденная Указом Презедента от 30 января 2010 года № 120. В соответствии с этим документом разработана Концепция развития отрасли до 2020 года.

Гусеводство, как любая отрасль птицеводства является резервом ускоренного увеличения производства мяса. Кроме того, развитие его оправдано тем, что гусинное мясо, отличаясь по вкусовым качествам от мяса других видов птиц, расширяет ассортимент мясных продуктов. Мясо молодых, 2-месячного возраста гусят-бройлеров известно, как ценный диетический продукт питания, а гусиная печень, получаемая при откорме специальных пород гусей (вишнитес, рейнских и др.), относятся к деликатесам. Гусиный жир используется в парфюмерной и фармацевтической промышленности, а пух и перо являются ценным сырьем для легкой промышленности (Н.Ковацкий, 1988; Г.Эльберт, М.Сниткин, 1988; В.Мамаев с соавт., 1988; В.Г.Цой, 2012).

Гуси являются уникальным и перспективным видом птицы, а гусеводство - высокоэффективной отраслью, способной давать существенную прибыль.

В отличие от других видов сельскохозяйственной птицы, гуси обладают способностью использовать грубые, сочные и зеленые корма, содержащие большое количество клетчатки, что позволяет получать продукцию при минимальных затратах концентрированных кормов (Я.Оноприенко, 1988; С.Неодобуга, 1988; И.Рак с соавт., 1988; Г.Тобоев, 2008).

Способность гусей удовлетворять свои потребности в питательных веществах за счет кормов естественных пастбищ и природных водоёмов определила целесообразность дальнейшего развития гусеводства на основе интеграции общественных хозяйств с личными подсобными хозяйствами населения (О.Божко, 1988; Н.Ковацкий, 1988).

Удовлетворение потребностей населения в суточных гусятах возложено на гусеводческие репродукторные фермы частного сектора, птицефабрики и инкубаторно-птицеводческие станции (ИПС), а также крупные гусеводческие комплексы.

Г.Эльберт, И.Сниткин (1988) отмечают, что для быстрейшего увеличения объёма производства мяса гусей, а также пухо-перового сырья и деликатесных продуктов необходимы строительство инкубаториев, создание 
при ИПС и птицефабриках родительских стад из высокопродуктивных пород, привлечение частного сектора к массовому выращиванию молодняка.

Одним из приемов повышения мясной продуктивности птицы является использование эффекта гетерозиса при скрещивании различных пород. Гибридное потомство, как правило, превосходит родительские формы и имеет лучшее развитие, повышенную жизнеспособность и продуктивность (В.И.Фисинин с соавт., 2012; В.М.Чаленко, 2012).

Дальнейшее увеличение производства мяса гусей возможно благодаря эффективному использованию кормов, оптимальному биологически обоснованному питанию птицы (М.Г.Петраш с соавт.,2004), что становится возможным за счет использования различных кормов и кормовых добавок (И.Егоров, 2007; С.Кислюк, 2008; Р.Р.Годиев, А.Р.Фаррахов, 2012; С.Ф.Суканова, А.Г.Махалов, 2012), в том числе ферментных селенсодержащих препаратов и синтетических аминокислот (А.Г.Махалов, 2008).

Развитие птицеводства подразумевает более широкое использование генофондных коллекций сельскохозяйственной птицы, в том числе гусей. В птицеводстве будущего все большую роль будут играть технологии генной инженерии. Причем не только использование генных маркеров и молекулярно-генетических методов в селекционной работе, но и технологии трансгенеза (В.И.Фисинин, 2012).

Важное место при совершенствовании и создании пород отводится технологии содержания гусей в селекционных гнездах, не снижая их продуктивных показателей (Р.Р.Годиев, А.Р.Фаррахов, 2012) и созданию генетического портрета пород гусей или генетической оценке генофонда пород (И.П.Жаркова, Д.С.Гришина, 2012).

Наша страна располагает значительным генофондом гусей: в настоящее время насчитывается 21 порода и породная группа. Для выращивания гусят на мясо определены наиболее перспективные породы: итальянская, рейнская, венгерская, линдовская, краснозерская. При откорме на жирную печень лучший эффект дают ландские, венгерские, тулузские и крупные серые гуси. Для реализации суточного молодняка населению, кроме указанных пород, можно разводить китайскую и оброшинскую породную группу, а по качеству пухо-перьевого сырья лучшими являются гуси породы вишнитес.

Анализируя современное состояние гусеводства в Российской Федерации в плане распространения и использования породного состава, следует констатировать, что более 50\% поголовья гусей в стране составляет линдовская порода. Столь широкое распространение линдовские гуси по- 
лучили благодаря их высоким продуктивным и воспроизводительным качествам. При этом данная порода отличается высокой жизнеспособностью и неприхотливостью к условиям содержания. В настоящее время разработан перспективный план племенной работы с линдовской породой гусей, который предусматривает выведение специализированных отцовских и материнских линий, а в последующем, на их основе - создание высокопродуктивного межлинейного мясного кросса гусей (Я.С.Ройтер с соавт., 2012).

Разработана технология круглогодичного производства мяса гусей в основе, которой лежит использование родительского стада в течение 2,5 лет. Два цикла яйцекладки у несушек позволяют получать инкубационные яйца 9 месяцев в году, т.е. в два раза дольше, чем по сезонной технологии. Продуктивность гусей возросла с 35 до 65-75 яиц.

В целях повышения оплодотворенности яиц (до 90-95\%) и сокращения числа гусаков в стаде (в три раза) внедряется искусственное осеменение птицы. Разработанный способ осеменения гусынь, техника получения спермы и среда для её разбавления отличаются новизной и не имеют аналогов в мире.

Интенсивное выращивание гусят-бройлеров на подстилке и сетчатых полах в клеточном режиме позволили сократить сроки их откорма, повысить эффективность использования помещений на 130\%, поднять производительность труда и снизить себестоимость прироста живой массы птицы.

Разработана технология принудительного откорма гусей на жирную печень, созданы экспериментальные машины для откорма птицы на 460500 голов за 21-23 суток принудительного откорма гусей, что соответствует мировому уровню.

Разработана технология получения пухо-перового сырья путём прижизненной общипки гусей. В основу разработки метода положены результаты научных исследований и практический опыт хозяйств (В.Мамаев с соавт., 1988).

Проведение разработанных ГНУ ВНИВИП Россельхозакадемии ветеринарно-санитарных мероприятий, а также применение рекомендаций по производству и переработке продукции гусеводства, разработанных во ГНУ ВНИТИП Россельхозакадемии и НПО «Комплекс» на основе результатов научных исследований, позволяют достичь высоких производственных показателей на гусеводческих предприятиях. 


\section{ГЛАВА 1.}

\section{Характеристика семейства парвовирусов}

Для семейства парвовирусов характерно исключительное разнообразие и широкий круг хозяев (от высших приматов до насекомых). В естественных условиях парвовирусы патогенны для млекопитающих, птиц, а также человека. Болезни, вызываемые ими, наносят существенный экономический ущерб животноводству многих стран. Кроме того, парвовирусы имеют уникальную структурно-функциональную организацию генома и являются хорошей моделью для изучения репликации односпиральной ДНК. Структура семейства Parvoviridae (согласно 8-му отчету Международного Комитета по Таксономии Вирусов) представлена ниже:

Семейство
Подсемейство
Род
Род
Род
Род
Род
Подсемейство
Род
Род
Род
Род

00.050. Parvoviridae

00.050.1. Parvoririnae
00.050.1.01. Parvovirus
00.050.1.02. Erythrovirus
00.050.1.03. Dependovirus
00.050.1.04. Amdovirus
00.050.1.05. Bocavirus

00.050.2. Densovirinae

00.050.2.01. Densovirus

00.050.2.02. Iteravirus

00.050.2.03. Brevidensovirus

00.050.2.04. Pefudensovirus

00.050.2.00. Неклассифицированные виды Подсемейства

Общим свойством парвовирусов является наличие в вирионах односпиральной линейной молекулы ДНК. В вирионах большинства представителей рода Parvovirus содержится минус-ДНК, однако было установлено, что у части вирионов (от 1 до 50\%) вируса Килхема, парвовирусов крупного рогатого скота, H1, Lu3 и В19 содержится плюс-ДНК. У представителей рода Dependovirus и Densovirus в вирионах содержится либо плюс-, либо минус-ДНК, причем каждый вид ДНК включается в вирионы с равной частотой. Плюс- и минус-ДНК комплементарны друг другу и in vitro объединяются с образованием двухспиральных молекул (G.Siegl, 1984 a,b; M.J.Anderson, J.R.Pattison, 1984; R.C.Bates et al., 1984). 
Структура, состав и физико-химические свойства. Вирионы парвовирусов представляют собой безоболочечные изометрические частицы с кубической симметрией, имеющие диаметр 18 - 26 нм; диаметр сердцевины - 14 - 17 нм (рис. 1 на вкладке).

Парвовирусы самые мелкие вирусы животных. Капсид парвовирусов состоит из 32 капсомеров диаметром 3 - 4 нм. Липидов, углеводов и ферментов в составе вирионов не обнаружено. Парвовирусы содержат единую односпиральную линейную ДНК с молекулярной массой 1,5 - 2,2 МД, что составляет 19 - 32\% массы вирионов. Молекулярная масса вирионов парвовирусов колеблется от 5,5 до 6,2 МД (R.E.F.Matthews, 1982; G.Siegl et al., 1985).

Коэффициент седиментации изученных парвовирусов составляет 110 - 122 $\mathrm{S}$, плавучая плотность в хлористом цезии - 1,39 - 1,42 г/см³. Частицы с плавучей

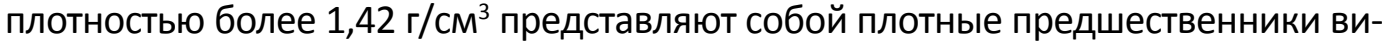

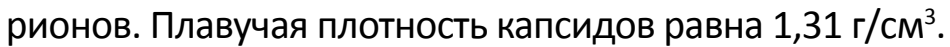

Парвовирусы стабильны при рН 3,0 - 9,0, прогревании при $56^{\circ} \mathrm{C}$ в течение часа, устойчивы к жирорастворителям, трипсину, пепсину, инактивируются ультрафиолетовыми лучами, формальдегидом, производными этиленимина, $\beta$-пропиолактоном, гидроксиламином, а также окисляющими агентами (Б.Б.Трефилов, 1982, 2000; P.Tattersall, D.Ward, 1978; R.E.F.Matthews, 1982; G.Siegl et al, 1985).

Структурные белки. Белки парвовирусов составляют 63 - 81\% массы вириона. В вирионах автономных и дефектных парвовирусов обнаружены полипептиды трех, денсовирусов - четырех типов. Основным белком у парвовирусов млекопитающих является полипептид VP3 и составляет около 80\% общего количества белка. Выявлены обширные участки гомологии у полипептидов VP1, VP2, VP3 (T.W.Molitor et al., 1983; F.B.Johnson, 1984; G.Siegl et al., 1985).

Структура генома. Геном парвовирусов представлен единой односпиральной линейной молекулой ДНК, которая состоит примерно из 5000 нуклеотидов и имеет коэффициент седиментации 15 - $18 \mathrm{~S}$. Молекулярная масса ДНК ААВ типа 2, мелкого вируса мышей вируса Килхема, Lu3, H1 и парвовируса крупного рогатого скота составляет соответственно 1,52; 1,66; 1,68; 1,69; 1,70 и 1,84 МД. Геномные ДНК парвовирусов инфекционны и по нуклеотидному составу заметно различаются ( P.T.Banerjee et al., 1983; C.R.Astell et al., 1983 а, в).

Антигенные свойства. Антигенная структура парвовирусов основана на сравнительном изучении степени их родства в РН, РСК, РТГА, методом флуоресцирующих антител и ПЦР. Так, парвовирус собак, вирус энтерита норок, вирус панлейкопении кошек антигенно близки (некоторые различия выявляются при использовании моноклоналъных антител). Слабое антигенное родство обнаружено между парвовирусами свиней и собак. Методом флуоресцирующих антител (МФА) выявлено незначительное антигенное родство у вирусов Килхема, Н1 и мелкого вируса мышей (G.Siegl, 1984 6; G.Siegl et al., 1985). 
Репродукция. Парвовирусы адсорбируются на клеточной мембране вследствие взаимодействия комплементарных рецепторов вируса и клеток и проникают в клетку посредством эндоцитоза. При оптимальных условиях репродукция вируса происходит быстро и заканчивается в течение 30 - 60 мин. Первые этапы репродукции парвовирусов (адсорбция, проникновение и депротеинизация) не зависят от фазы клеточного цикла (I.Majaniemi, G.Siegl, 1984). Геномы автономных и дефектных парвовирусов транскрибируются в ядре клетки клеточной РНКполимеразой, причем считается только минус-нить ДНК в составе репликативной формы.

Закономерности транскрипции генома автономных и дефектных парвовирусов детально изучены на моделях мелкого вируса мышей и АДВ типа 2 (B.J.Carter et al., 1984). Геном мелкого вируса мышей содержит две перекрещивающиеся транскрипционные единицы с отдельными промоторами в положении 4 и 39 ед. карты.

В отличие от автономных парвовирусов у парвовирусов ААВ типа 2 в геноме содержится три перекрывающиеся транскрипционные единицы с отдельными промоторами в положениях 5, 19 и 40 ед. карты (A.Srivastava et al., 1983; B.J.Carter, C.A.Laughlin, 1984).

Таким образом, и-РНК у парвовирусов синтезируются на перекрывающихся транскрипционных единицах генома со специфических промоторов. Гены, кодирующие структурные белки, расположены в 5'- концевой части генома, а неструктурные - в 3' - концевой части генома.

В клетках, инфицированных парвовирусами, синтезируются 4 - 5 вирусспецифических белков: 3 структурных и 1 - 2 неструктурных, функциональная роль которых пока не выяснена; полагают, что неструктурные белки участвуют в репликации вирусной ДНК. Методом иммунофлуоресценции специфические белки сначала выявляются в цитоплазме, а затем в ядре клетки (A.Srivastava et al., 1983; C.R.Astell et al., 1983).

ДНК автономных и дефектных парвовирусов реплицируется в ядрах делящихся клеток; репродукция их подавляется любым ингибитором синтеза клеточной ДНК. Обнаружена корреляция между синтезом вирусной и клеточной ДНК: максимальная скорость синтеза вирусной ДНК совпадает с S-фазой клеточного цикла (W.W.Hauswirth, 1984).

Созревание вирионов парвовирусов происходит в ядрах инфицированных клеток. Установлено, что синтезированные белки быстро мигрируют из цитоплазмы в ядро и формируют капсидные структуры, в которые упаковываются вирусные ДНК. Зрелые вирионы автономного парвовируса Lu3 образуются в течение 10 - 15 мин. после упаковки ДНК в вирусные капсиды (D.E.Müller, G.Siegl, 1983).

Патогенность. Для парвовирусов, как правило, характерен узкий круг патогенности; исключение составляют парвовирусы плотоядных и птиц. Многие 
представители впервые были выделены от естественно чувствительных животных (табл.1). Парвовирусы свиней, крупного рогатого скота, лошадей и кроликов в естественных и экспериментальных условиях вызывают заболевание только у одного вида животных. Вирус энтерита гусей в естественных условиях патогенен для гусят и мускусных утят, и также был адаптирован к эмбрионам пекинских уток.

Парвовирусы вызывают энтериты у телят, норок, собак, кошек и гусей чаще в первые месяцы после рождения. Репликация их происходит в эпителиальных клетках тонкого отдела кишечника инфицированных животных.

Гепатит - основное клиническое проявление парвовирусной инфекции гусят в первый месяц жизни. В этот период отмечается высокая митотическая активность клеток печени. С возрастом устойчивость гусят к заражению парвовирусом повышается, что, вероятно, обусловлено снижением активности клеток печени (G.Siegl, 1984a).

Таблица 1

Характеристика парвовирусов животных

\begin{tabular}{|c|c|c|c|c|c|}
\hline \multirow[b]{2}{*}{ Название } & \multirow[b]{2}{*}{$\begin{array}{c}\text { Источник } \\
\text { первичного } \\
\text { выделения }\end{array}$} & \multirow[b]{2}{*}{$\begin{array}{c}\text { Естествен- } \\
\text { ный } \\
\text { хозяин }\end{array}$} & \multicolumn{2}{|c|}{ Репликация } & \multirow[b]{2}{*}{$\begin{array}{c}\text { Агглютинация } \\
\text { эритроцитов }\end{array}$} \\
\hline & & & $\begin{array}{c}\text { В первично- } \\
\text { трипсиниз. } \\
\text { культурах } \\
\text { клеток }\end{array}$ & $\begin{array}{c}\text { В перевива- } \\
\text { емых культу- } \\
\text { рах клеток }\end{array}$ & \\
\hline $\begin{array}{l}\text { Парвовирус } \\
\text { свиней }\end{array}$ & $\begin{array}{c}\text { Первич. к/к } \\
\text { почек } \\
\text { поросят }\end{array}$ & Свиньи & $\begin{array}{c}\text { Почек, } \\
\text { тестикул и } \\
\text { щитовид- } \\
\text { ные железы } \\
\text { поросят }\end{array}$ & $\begin{array}{c}\text { PK-15 /почки } \\
\text { поросят/ ST/ } \\
\text { тестикулы } \\
\text { поросят }\end{array}$ & $\begin{array}{l}\text { Морской } \\
\text { свинки и } \\
\text { человека }\end{array}$ \\
\hline $\begin{array}{l}\text { Парвовирус } \\
\text { крупного ро- } \\
\text { гатого скота }\end{array}$ & $\begin{array}{l}\text { Фекалии } \\
\text { телят }\end{array}$ & $\begin{array}{c}\text { Крупный } \\
\text { рогатый } \\
\text { скот }\end{array}$ & $\begin{array}{c}\text { Почек, лег- } \\
\text { ких и селе- } \\
\text { зенки плода } \\
\text { коровы }\end{array}$ & $\begin{array}{c}\text { Легкие буй- } \\
\text { вола }\end{array}$ & $\begin{array}{l}\text { Морской } \\
\text { свинки и } \\
\text { человека }\end{array}$ \\
\hline $\begin{array}{l}\text { Парвовирус } \\
\text { лошадей }\end{array}$ & $\begin{array}{c}\text { Легкие } \\
\text { плодов } \\
\text { лошадей }\end{array}$ & Лошади & Нет данных & $\begin{array}{c}\text { PFT /яйцевод } \\
\text { свиньи/ }\end{array}$ & $\begin{array}{c}\text { Морской } \\
\text { свинки }\end{array}$ \\
\hline $\begin{array}{l}\text { Вирус алеут- } \\
\text { ской болезни } \\
\text { норок }\end{array}$ & $\begin{array}{l}\text { Ткани } \\
\text { норок }\end{array}$ & Норки & $\begin{array}{c}\text { Почек но- } \\
\text { рок, кошек } \\
\text { и хорьков }\end{array}$ & $\begin{array}{c}\text { CCC/81, } \\
\text { CRFK /почки } \\
\text { кошек/ }\end{array}$ & $\begin{array}{c}\text { Не агглютини- } \\
\text { рует }\end{array}$ \\
\hline $\begin{array}{l}\text { Вирус энтери- } \\
\text { та норок }\end{array}$ & $\begin{array}{l}\text { Ткани } \\
\text { норок }\end{array}$ & Норки & $\begin{array}{c}\text { Почек ко- } \\
\text { шек }\end{array}$ & $\begin{array}{c}\text { CRFK /почки } \\
\text { кошек/ }\end{array}$ & Свиней \\
\hline $\begin{array}{l}\text { Парвовирус } \\
\text { кроликов }\end{array}$ & $\begin{array}{l}\text { Фекалии } \\
\text { кроликов }\end{array}$ & Кролики & $\begin{array}{c}\text { Почек кро- } \\
\text { ликов }\end{array}$ & $\begin{array}{l}\text { РК /почки } \\
\text { кроликов/ }\end{array}$ & $\begin{array}{c}\text { Морской } \\
\text { свинки }\end{array}$ \\
\hline
\end{tabular}




\begin{tabular}{|c|c|c|c|c|c|}
\hline $\begin{array}{l}\text { Мелкий вирус } \\
\text { собак* }\end{array}$ & $\begin{array}{c}\text { Фекалии } \\
\text { собак }\end{array}$ & Собаки & Нет данных & $\begin{array}{c}\text { WRCC /ткани } \\
\text { собак/ }\end{array}$ & Обезьян \\
\hline $\begin{array}{l}\text { Парвовирус } \\
\text { собак** }\end{array}$ & $\begin{array}{l}\text { Фекалии } \\
\text { собак }\end{array}$ & Собаки & $\begin{array}{l}\text { Почек собак } \\
\text { и кошек }\end{array}$ & $\begin{array}{l}\text { МДСК /поч- } \\
\text { ки собак/, } \\
\text { CRFK /почки } \\
\text { кошек/, А-72 } \\
\text { /опухоль со- } \\
\text { бак/ }\end{array}$ & $\begin{array}{l}\text { Свиней и обе- } \\
\text { зьян }\end{array}$ \\
\hline $\begin{array}{l}\text { Вирус пан- } \\
\text { лейкопении } \\
\text { кошек }\end{array}$ & $\begin{array}{l}\text { Ткани ко- } \\
\text { шек }\end{array}$ & Кошки & $\begin{array}{l}\text { Почек ко- } \\
\text { шек }\end{array}$ & $\begin{array}{l}\text { CRFK /почки } \\
\text { кошек/ }\end{array}$ & Свиней \\
\hline $\begin{array}{l}\text { Вирус энтери- } \\
\text { та гусей }\end{array}$ & Ткани гусей & Гуси & $\begin{array}{l}\text { Эмбрион гу- } \\
\text { сей и уток }\end{array}$ & Нет данных & $\begin{array}{l}\text { Не агглютини- } \\
\text { рует }\end{array}$ \\
\hline $\begin{array}{l}\text { Парвовирус } \\
\text { кур }\end{array}$ & $\begin{array}{l}\text { Кишечник } \\
\text { цыплят }\end{array}$ & куры & Нет данных & Нет дынных & Нет данных \\
\hline $\begin{array}{l}\text { Вирус Килхе- } \\
\text { ма }\end{array}$ & $\begin{array}{l}\text { Опухолевые } \\
\text { ткани крыс }\end{array}$ & Крысы & $\begin{array}{l}\text { Эмбрионов } \\
\text { крыс }\end{array}$ & $\begin{array}{l}\text { Нефромы } \\
\text { крыс }\end{array}$ & $\begin{array}{l}\text { Морской } \\
\text { свинки и } \\
\text { человека }\end{array}$ \\
\hline $\begin{array}{l}\text { Мелкие виру- } \\
\text { сы мышей }\end{array}$ & $\begin{array}{l}\text { Сток адено- } \\
\text { вируса мы- } \\
\text { шей. }\end{array}$ & Мыши & $\begin{array}{l}\text { Эмбрионы } \\
\text { мышей и } \\
\text { крыс }\end{array}$ & $\begin{array}{l}\text { А-9 /дериват } \\
\text { клеток/ }\end{array}$ & $\begin{array}{l}\text { Морской } \\
\text { свинки }\end{array}$ \\
\hline Lu III & $\begin{array}{l}\text { Линия кле- } \\
\text { ток челове- } \\
\text { ка Lu } 106\end{array}$ & Неизвест. & Нет данных & $\begin{array}{l}\text { Hela / } \\
\text { опухоль } \\
\text { человека/, } \\
\text { NB /почки } \\
\text { человека/ }\end{array}$ & $\begin{array}{l}\text { Морской } \\
\text { свинки и } \\
\text { человека }\end{array}$ \\
\hline B19 & $\begin{array}{l}\text { Сыворотка } \\
\text { крови чело- } \\
\text { века }\end{array}$ & Человек & Нет данных & Нет данных & $\begin{array}{l}\text { Не агглютини- } \\
\text { рует }\end{array}$ \\
\hline
\end{tabular}

* - мелкий вирус собак обозначают как парвовирус собак типа 1;

** - парвовирус собак обозначают как парвовирус собак типа 2.

Таким образом, парвовирусы животных по своим свойствам разделяются на автономные и дефектные. Первые патогенны для многих видов животных и птиц. Они высокоустойчивы во внешней среде и сохраняются в помещениях до 4-6 месяцев и, обладая высокой стабильностью в лабораторных условиях, они представляют большую опасность, как контаминаты клеточных культур, препаратов вирусов и вакцин (P.Tattersall, D.Ward, 1978; R.E.F.Matthews, 1982; G.Siegl et al, 1985). 


\section{ГЛАВА 2. \\ Парвовирус гусей и его биологические свойства (генетические признаки)}

Знание генетических признаков вирусных штаммов, их стабильности, взаимосвязи и отношения к патогенности, а также наличие простых и доступных методов, позволяющих выявлять изменения маркеров, является одним из важных условий, определяющих успешность исследований в области вирусной генетики и в том числе в деле получения вакцинных вирусных штаммов.

В последние годы достигли большого прогресса в изучении механизма взаимодействия вируса и клетки, в частности раскрыт ряд процессов, обуславливающих репродукцию парвовируса гусей в клетке.

В этой главе представлены данные, накопленные в этом направлении, как в отечественной, так и в зарубежной литературе в отношении парвовируса гусей.

\section{1.Этиологические факторы}

C.H.Schettler (1971a) доказал, что возбудителем вирусного энтерита гусей является фильтрующийся вирус. Позднее это открытие было подтверждено и другими исследователями (Г.А.Надточей с соавт., 1975; Д.Держи с соавт., 1975; Л.М.Контримавичус, 1977; A.A.S.Ahmed, 1973; D.Derzsy, 1967, 1973; J.Kisary, 1974; J.Kisary et al., 1975a, в; J.Kisary, J.Meszaros, 1977; 1980; W.Peter, 1982). Авторы вирус относят к семейству Parvoviridae, роду Parvovirus (Picodnavirus), виду P.goose.

В последние годы имеется достаточное количество работ, свидетельствующих о вирусной этиологии болезни (Л.М.Контримавичус с соавт., 1966; Г.А.Надточей с соавт., 1975; L.Csontos, M.Csatari, 1967a; G.Dannacher et al., 1972, 1974; D.Derzsy et al., 1966; J.Hoekstra et al., 1973; H.Krauss, 1965; C.H.Schettler, 1971a). Ими были выделены вирусные агенты и воспроизведено первоначальное заболевание у восприимчивой птицы, при заражении ее фильтратами из патологического материала и вирусными изолятами. Вирусные штаммы «В» (J.Kisary et al., 1975a, в), "ЛИ» (Л.М.Контримавичус, 1975; Г.А.Надточей с соавт., 1975), YHV - SHB - 319 (C.H.Schettler, 1971в), «SH» (D.Gaudry et al., 1972), «Beta» (G.Dannacher et al., 1972), «Duth» (J.Hoekstra, H.Yadin, 1973) были классифицированы как парвовирусы, вызывающие болезнь Держи (вирусный энтерит) гусей.

При изучении этиологии болезни исследователи из патологического материала павших гусей выделяли различные вирусы, отличные по физико-химическим и биологическим свойствам от парвовируса, к числу которых относились реовирусы (H.Krauss, 1967, 1968; L.Csontos, M.Csatari, 1967в; A.Rinaldi et al., 1970; D.Derzsy et al., 1975; W.Peter, 1982), герпесвирус (Э.А.Преображенская с соавт., 
1973 а, б), аденовирусы (L.Csontos, M.Csatari,1967 a, б; W.Peter, 1982), пикорнавиpyc (G.Fenske et al., 1975).

Однако при бактериологических и микологических исследованиях из внутренних органов павших гусят в период эпизоотии выделяли различные виды патогенных и условно-патогенных микроорганизмов: Bact septicaemiae anserum exudative, (L.Csontos, M.Csatari, 1967a, b), Haemophilus anserisepticus Riemer; Salm. typhimurium (E.F.Kaleta, 1969), Salm. pullorum (В.С.Фадин, 1973в; А.Ф.Бондаренко, М.В.Капитанаки, 19756); E. coli, Cl. perfringens (Л.М.Контримавичус, 1975a); стафилококки и стрептококки.

Эти данные не подтвердили бактериальную природу болезни, а лишь указывают на то, что выделенные возбудители (бактерии и вирусы) изменяли клиническую картину, патологоанатомические признаки и осложняли течение вирусного энтерита, затрудняли диагностику заболевания (Л.М.Контримавичус, 1968, 1972, 1975а; В.Ф.Макогон с соавт., 1974; Н.М.Мельников, В.С.Фадин, 1973; V.Bergmann, 1987).

A.Vuillaume et al. (1982) отмечают, что часто условия выращивания водоплавающей птицы определяют причину возникновения и степень тяжести течения болезни. К ним авторы относят отсутствие хороших санитарно-гигиенических условий кормления и содержания, несбалансированное питание по белку, витаминам, микроэлементам и энергетическим ресурсам, неудовлетворительный микроклимат и некачественную дезинфекцию ферм и выгульных площадок.

Таким образом, первопричиной возникновения вирусного энтерита является парвовирус гусей.

\section{2. Морфология вирусной частицы}

Морфологическая структура вирусов является одним из наиболее стабильных генетических признаков и в связи с этим служит главным из основополагающих критериев современной классификации вирусов.

Парвовирус гусей (Goose parvovirus, (GPV), код вируса в базе данных MKTB: 00.050.1.03.013.00.001.) является одним из видов, входящих в состав рода Dependovirus (00.050.1.03.), подсемейства Parvovirinae, семейства Parvoviridae. С использованием поликлональных антител и экспериментального инфицирования животных было установлено, что представители каждого вида, входящего в состав этого семейства, имеют антигенные различия и обычно ограничены единичными видами-хозяевами. В целом, виды семейства обладают < 95\% идентичностью неструктурных генных последовательностей ДНК.

Величина вириона по данным различных авторов варьирует в пределах 20-22 нм: Д.Держи с соавт. (1975); Л.М.Контримавичус (1975); Г.А.Надточей 
с соавт. (1975); D.Derzsy et al., (1975); J.Kisary et al., (1975в); G.Mandelli et al., (1970); C.H.Schettler (1973); G.Dannacher et al., (1974); J.Kisary, D.Derzsy (1974). Работами исследователей установлено, что вирусные частицы представляют собой мелкие сферические образования, расположенные в виде агрегатов или отдельных частиц и имеют икосаэдрический тип симметрии капсида с толщиной капсомера около 2 нм. Суперкапсидная оболочка отсутствует. Часть вирионов имеет плотный (темный) центр и светлое кольцо капсомеров по краю (пустые вирионы). На поверхности полных вирионов видна структура капсомеров.

Е.А.Петелина (1984) сообщила, что вирионы парвовируса гусей имеют икосаэдрический тип симметрии, состоят из нуклеотида и капсомерного слоя толщиной 2 нм. В «пустых» частицах видна электронно-плотная внутренняя полость в диаметре 16,25 \pm 0,075 нм. Средний диаметр вирионов равен 21,48 $\pm 0,086$ нм.

По данным многих авторов (Л.М.Контримавичус 1975 а, б; Г.А.Надточей с соавт., 1975; Е.А.Петелина, 1976, 1984; C.H.Schettler, 1971a, 1973; G.Dannacher et al., 1974; J.Kisary, D.Derzsy, 1974; 1975;) установлено, что нуклеокапсид вируса содержит дезоксирибонуклеиновую кислоту.

При изучении цитопатологии, вызванной парвовирусом гусей, штамм «Beta», G. Dannacher et al., (1974) обнаруживали в ядрах клеток чередование темных и светлых участков. Темные зоны представляли собой плотные виропласты, а светлые участки состояли из небольших скоплений вирусных частиц размером 20 нм.

Д.Держи с соавт. (1975), обнаружили мелкие сферические вирионы, собранные в агрегаты или располагающиеся дисперсно, в виде отдельных частиц, методом негативного контрастирования в препаратах штаммов «Ю», «ЛИ» и «НВ». В популяции вируса выявили полные и пустые нуклеокапсиды без суперкапсидной оболочки, в диаметре 18-22 нм. Толщина капсидной оболочки около 2 нм.

Е.А.Петелина $(1976,1984)$ отмечала, что при изопикническом центрифугировании плавучая плотность вируса энтерита гусей, штамм «ЛИ», в гра-

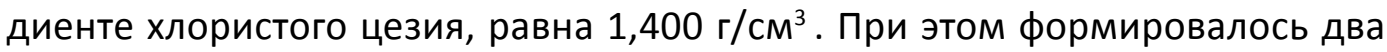

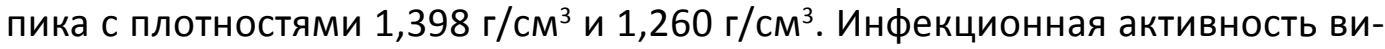
руса локализовалась в I пике и достигала титра 6,0 Ig ТЦД ${ }_{50}$, тогда как во II пике и в средней зоне между пиками титр вируса был ниже на 1,0 lg ТЦД По данным J.Kisary (1976), плавучая плотность парвовируса гусей, штамм «B», в градиенте хлористого цезия составила 1,380 г/см³.

J.Kisary et al. (1984) при изучении этиологического фактора синдрома отставания в росте и плохого оперения у цыплят в гомогенате кишечника обнаружили гексогональные вирусные частицы в диаметре 19 - 24 нм, относящиеся к семейству Parvoviridae, с плавучей плотностью в градиенте хлори- 
стого цезия 1,42 - 1,44 г/см³ , и авторы связывают их с парвовирусом болезни Держи у гусей.

R.Kokles et al. (1985) сообщили о выявлении при электронно-микроскопическом исследовании в аллантоисной жидкости зараженных 10-суточных гусиных эмбрионов на 8 - 12-е сутки после инокуляции множества частиц парвовирусной морфологии.

По данным V.Bergmann (1987) в клетках сердечной мышцы и бурсы Фабрициуса обнаруживались гексогональные частицы вируса величиной 20 - 22 нм, которые по месту репликации и морфологии были классифицированы как парвовирусы. Наряду с полными нуклеокапсидами присутствовали пустые, без ядерного вещества парвовирусы. Иногда отмечались парануклеарные конгломераты вируса в виде кристаллических скоплений. Наличие цитоплазматических конгломератов парвовируса свидетельствовало о высвобождении из ядра вирусных агрегатов.

При электронно-микроскопическом исследовании препаратов, приготовленных из инфицированной клоном 6 парвовируса культуры клеток гусинных эмбрионов методом негативного контрастирования, установлено наличие в них вирусных частиц, расположенных отдельно и в виде скоплений, размером 19-20 нм (рис.2 на вкладке). Капсид имел кубический тип симметрии. При исследовании ультратонких срезов в цитоплазме зараженных клеток обнаруживали вирусные частицы величиной 19-20 нм, связанные с мембранами эндоплазматического ритикулома иногда формирующие кристаллические скопления (Б.Б.Трефилов, 2000). Для изучения ДНК природы нуклеиновой кислоты вируса применяют метод ингибирования 5-бром-2-дезоксиуридином или 5-йод-2-дезоксиуридином его репликации в культуре гусиных фибробластов (Б.Б.Трефилов, И.В.Щеглова, 1989).

\section{3. Патогенность для эмбрионов}

Одним из основных биологических свойств вирусов является их вирулентность. Вирулентность представляет собой качество или степень патогенности. При изучении последней у восприимчивых животных М.В.Рево, М.Д.Жукова (1958) рекомендуют учитывать продолжительность инкубационного периода, форму течения инфекционного процесса, выраженность и характер клинических признаков, сроки гибели животных и наличие специфических патологических изменений.

Вирулентность, как индивидуальную особенность штамма возбудителя, приходится учитывать при оценке возникшего инфекционного процесса и общей обстановки развивающейся эпизоотии (М.С.Ганнушкин, 1965). 
A.M.Woodruff, E.M.Goodpasture (1931) разработали метод культивирования вирусов в развивающихся куриных эмбрионах. Простота метода по технике выполнения, не требующего сложного оборудования, позволила широко использовать эту методику в вирусологической практике.

D.Derzsy et al. (1966), D.Derzsy (1967) первыми выявили способность парвовируса репродуцироваться в развивающихся гусиных эмбрионах.

В дальнейшем для репликации вируса использовали 9 - 11-суточные гусиные эмбрионы (Л.М.Контримавичус, 1971; В.И.Корнеева с соавт., 1973; Б.Б.Трефилов, 1976; C.H.Schettler, 1971в; R.E.Gough et al., 1981; D.U.Fang et al., 1981; J.F.Bouquet et al., 1981), а также 10 - 11-суточные эмбрионы мускусных уток (J.Hoekstra et al., 1973; N.V.Hanh, 1974; R.E.Gough, D.Spackman, 1982). Заражение эмбрионов авторы проводили инокуляцией в аллантоисную полость суспензией органов (печени, сердца, селезенки, кишечника) больной или павшей птицы.

По наблюдениям Л.М.Контримавичус (1971, 1972, 1974 а, б), М.B.Капитанаки с соавт. (1971), R.Kokles et al. (1985) гибель эмбрионов наступала через 2 - 10 суток после заражения, а по данным D.Derzsy et al. (1975), при последующих пассажах вируса на гусиных эмбрионах, их гибель отмечалась уже на 2 - 6 сутки.

Д.Держи с соавт. (1975) описали результаты изучения патогенных свойств 16-ти изолятов вируса на развивающихся гусиных эмбрионах в процессе 4 - 20 пассажей. Уже на впервых трех пассажах гибель эмбрионов достигала 10 - 30\%. При дальнейшем кулътивировании вирулентность изолятов вирусов усиливалась. Патологоанатомические изменения у гусиных эмбрионов, вызываемые штаммами, выделенными в Венгрии и СССР, были аналогичными.

Г.А.Надточей с соавт. (1975) культивировали штаммы вируса энтерита на 10 - 12-суточных гусиных эмбрионах (5 - 8 пассажей). Штаммы вызывали гибель эмбрионов с характерными патологоанатомичесними изменениями: отеком, гиперемией тела эмбриона, особенно конечностей и клюва, кровоизлияниями на коже, дегенерацией сердечной мышцы, печени, отеком хориоаллантоисной оболочки.

Б.Б.Трефилов (1976) показал, что по патогенности для гусинных эмбрионов все испытуемые штаммы вируса характеризовались как Pgle+ штаммы.

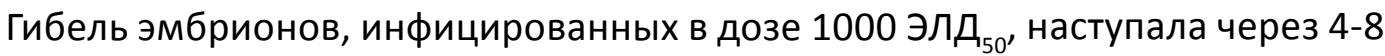
суток после инокуляции в $100 \%$ случаях. У павших эмбрионов отмечались отек хориоаллантоисной оболочки, подкожной клетчатки, гипертрофия сердца, изменение цвета миокарда, увеличение печени и почек, нарушение гемодинамики зародыша, что выражалось в гиперемии кожного покрова и наличии точечных кровоизлияний. Патологоанатомические изменения были свойственны штамму парвовируса (рис. 3 на вкладке). 
J.Kisary, D.Derzsy (1974), Л.М.Контримавичус (1974а) отмечали, что использование эмбрионов старше 10-суточного возраста нецелесообразно вследствие существенного снижения репродукции вируса.

Авторы обнаруживали у эмбрионов, павших впервые 2 - 4 суток, гиперемию, кровоизлияния на коже и отек хориоаллантоисной оболочки. У эмбрионов старшего возраста отмечали отек подкожной клетчатки в затылочной части головы и шеи, гиперемию и точечные кровоизлияния на клюве, крыльях и нижних конечностях, особенно перепонках, дегенерацию сердца и печени. В редких случаях наблюдали кровоизлияния в мозг, а также гиперемию и отек всего тельца эмбриона (Л.М.Контримавичус, 1974a; D.Derzsy et al., 1975).

D.Y.Fang, Y.K.Wang (1981) установили, что при длительном пассажировании вируса на гусиных эмбрионах он становился аттенуированным и не вызывал гибели гусят. Впоследствие его использовали для вакцинации гусей родителей в Китае.

По данным R.E.Gough, D.Spackman (1982) вирус болезни Держи при культивировании в утиных эмбрионах в течение 22 пассажей стал апатогенным для 1 - 3-суточных гусят.

J.Hoekstra et al. (1982) сообщили об умеренной вирулентности вируса энтерита для эмбрионов пекинских уток.

J.Kisary (1974) показал, что вариант «BAV» вируса болезни Держи, ослабленной вирулентности, размножался в гусиных эмбрионах, не вызывая их гибели, тогда как зараженные исходным штаммом «В» эмбрионы погибали в течение 4 - 6-ти суток.

J.Kisary (1985) отмечал, что при заражении SPF - куринных эмбрионов штаммом «АВИ» парвовируса, выводимость цыплят снижалась и значительное колличество их погибало от энтерита.

W.Peter (1985) сообщил о выделении 9 штаммов парвовируса гусей различной вирулентности для 12 - 14-суточных гусиных эмбрионов в период эпизоотии 1982-83 г.г. в ГДР.

Таким образом, культивирование вируса на эмбрионах различных видов птиц создает условия для аттенуации штаммов парвовируса и использования их для производства вакцин.

\section{4. Патогенность для птиц}

Большое значение в изучении болезни занимают вопросы восприимчивости различных видов птиц и пути передачи этой инфекции.

Известно, что патогенность вирусов для восприимчивого хозяина - свойство, представляющее собой суммарное проявление многих наследственно закрепленных особенностей вируса. 
В естественных условиях патогенность парвовируса была установлена для домашних (Л.М.Контримавичус с соавт., 1966; С.A.M.Cleef, van J.T.Miltenburg, 1966; L.Contos, M.Csatari, 1967в; Л.М.Контримавичус, 1968, 1975; S.Bernath, F.Szalai, 1970; М.В.Капитанаки с соавт., 1971; В.С.Фадин с соавт., 1973; В.Ф.Макогон с соавт., 1974), диких видов гусят: канадских (Branta canadensis), "снеговых" (Anser coerulescens) и мускусных утят (Cairina moschata) в возрасте до 30 суток (J.Hoekstra, H.Yadin, 1973). Авторы заражали их фильтратами и суспензией из патологического материала павшей птицы. В своих исследованиях использовали различные методы заражения (подкожный, внутримышечный, пероральный, аэрозольный, перитонеальный) гусят.

При экспериментальном заражении утят (пекинской и хаки-кембеллской пород), цыплят, индюшат, взрослых гусей и уток (J.Hoekstra, H.Yadin, 1973; J.Kisary, D.Derzsy, 1974; Л.M.Контримавичус, 1974a; G.Fenske et al., 1975; H.Hansen, 1979; 1980; R.E.Gough et al., 1981), а также лабораторных животных (В.С.Фадин, 19756) не установлено клинических проявлений парвовирусной инфекции.

C.H.Schetter (1971a) в эксперименте обнаружил, что гусята в 1 - 3-суточном возрасте заболели при заражении их внутримышечно в дозе $1,0 \mathrm{~cm}^{3}$ амниоаллантоисной вируссодержащей жидкостью гусиных эмбрионов, инфицированных парвовирусным изолятом 5-го пассажа. Болезнь проявилась у инфицированных и контактных гусят через 5 - 7 суток после инокуляции.

J.Kisary (1974) показал, что у восприимчивых гусят аттенуированный вариант «BAV» штамма «B» вируса болезни Держи не вызывал заболевания, не задерживал их развитие. Исходный штамм «В» индуцировал болезнь у гусят через 5 - 8 суток после заражения их в суточном возрасте (J.Roszkowski et al., 1982). Авторы обнаружили вирусный антиген в клетках печени павших гусят иммунопероксидазным методом.

Е.А.Петелина (1983) показала патогенность эпизоотического штамма «ЛИ» для гусят и его репликацию в энтероцитах тонкого отдела кишечника и гепатоцитах. Аттенуированный штамм индуцировал слабые изменения в энтероцитах и единичных клетках печени.

W.Peter (1985) воспроизвел заболевание у 1 - 2 - суточных гусят путем инокуляции суспензии патматериала от павших гусят и амниоаллантоисной жидкости, зараженных эмбрионов штаммами «32/82» и «17/83». Штаммы вируса показали различный спектр вирулентности, так как автор не учитывал наличие материнского иммунитета у гусят. Гибель их наблюдалась на 5, 8, 9, 11 и 21 сутки после инфицирования.

R.Kokles et al. (1985) отмечали, что при естественном течении болезни у гусят в возрасте 8 - 21 суток летальность составила почти 100\%, а в возрасте старше трех недель - она значительно снизилась.

В опытах R.E.Gough (1987) установил патогенность парвовируса для суточных гусят, из 24 зараженных пало 15 гусят с клиническимим признаками 
и патологоанатомическими изменениями болезни Держи.

B.Poonia et al. (2006) зарегистрировали болезнь мускусных утят в Пенсильвании, которая характеризовалась нарушением двигательной функции, слабостью конечностей и сопровождалась 40-60\% заболеваемостью и 10-40\% смертностью молодняка. Изолят вируса был классифицирован как парвовирус.

Таким образом, восприимчивость птиц к парвовирусу гусей зависит от их вида и возраста, а патогенность возбудителя определяется свойством штамма вируса. Изменение патогенности не является результатом мутации в каком-то единичном цистроне вирусной нуклеиновой кислоты, а представляет собой проявление комплексного изменения ряда свойств вируса. Поэтому она оказывается весьма ценным фактором при отборе и контроле вакцинных вирусных штаммов (Ю.3.Гендон, 1964).

\section{5. Устойчивость парвовируса к физико-химическим факторам}

Накопленные в последние годы данные свидетельствуют о том, что парвовирусы устойчивы к воздействию эфира, хлороформа, 0,25\% раствора трипсина, высоких температур и колебаниям значений рН среды. Вирус в патологическом материале сохраняется более 2 лет в 40\% растворе глицерина при температуре $4{ }^{\circ} \mathrm{C}$, а в лиофилизированном состоянии более 5 лет.

Вирус устойчив к обычным дезинфицирующим средствам, содержащим хлор и йод, но теряет свою инфекционную активность при обработке 0,5- 1\% раствором формальдегида через 15 минут (H.C.Hansen, 1980).

Инактивирующий эффект на вирус энтерита гусей оказывали формальдегид в $0,06 \%$ концентрации при $37^{\circ} \mathrm{C}$ в течение 48 часов или прогревание при $60{ }^{\circ} \mathrm{C}$ в течение 2 часов. Однако гидроксиламин 0,05 и 0,07 М и формальдегид 0,02 и 0,04\% в конечных концентрациях в течение 2, 5, 9, 24 и 48 часов экспозиции или прогревание при $56{ }^{\circ} \mathrm{C}$ в течение 4 часов не снижали инфекционный титр вируса (В.С.Фадин, А.В.Куриленко, 1981).

Результаты исследования по терморезистентности (Б.Б.Трефилов, 1976) показали, что штаммы парвовируса являются гомогенными в отношении термочувствительности, они существенно не отличаются по скорости инактивации и характеризуются как терморезистентные штаммы (T60+).

Выживаемость парвовируса гусей в фильтрате патологического материала, амниоаллантоисной и культуральной вируссодержащей жидкости при воздействии физико-химических факторов представлены в табл.2. 
Таблица 2

Выживаемость парвовируса гусей

\begin{tabular}{|c|c|c|c|c|}
\hline Автор, год & Среда, $\mathrm{pH}$ & $\begin{array}{c}\text { Темпе- } \\
\text { ратура, } \\
{ }^{\circ} \mathrm{C}\end{array}$ & $\begin{array}{c}\text { Время воз- } \\
\text { действия }\end{array}$ & $\begin{array}{c}\text { Устойчивость } \\
\text { вируса к воз- } \\
\text { действию }\end{array}$ \\
\hline 1 & 2 & 3 & 4 & 5 \\
\hline
\end{tabular}

а) амниоалантоисная или культуральная жидкости

\begin{tabular}{|c|c|c|c|c|}
\hline \multirow{10}{*}{$\begin{array}{c}\text { Л.М. } \\
\text { Контримавичус, } \\
\text { 1970а, } 1978\end{array}$} & 20\% эфир & 4 & $18-204$ & \multirow{10}{*}{ устойчив } \\
\hline & 50\% хлороформ & 22 & 15 мин & \\
\hline & pH от 3 до 12,5 & 22 & 34 & \\
\hline & 0,25\% трипсин 1:10 & 37,5 & 14 & \\
\hline & в присутствии $\mathrm{MgCl} 2$ & 70 & 40-60 мин & \\
\hline & \multirow{4}{*}{ температура } & 60 & 60 мин & \\
\hline & & 65 & 30 мин & \\
\hline & & 70 & 10-30 мин & \\
\hline & & 37,5 & 2-6 сут & \\
\hline & 40\% глицерин & 4 & 2-5 лет & \\
\hline \multicolumn{5}{|c|}{ б) лиофилизированный } \\
\hline $\begin{array}{c}\text { Л.М. Контримави- } \\
\text { чус, 1970а, } 1978\end{array}$ & желатин + пептон & +22 & 5 лет & устойчив \\
\hline \multicolumn{5}{|c|}{ в) культуральная вируссодержащая жидкость } \\
\hline \multirow{5}{*}{ C.H.Schettler, 1971} & температура & 56 & 60 мин & \multirow{5}{*}{ устойчив } \\
\hline & $\begin{array}{c}20 \% \text { эфир, } 10 \% \text { хлоро- } \\
\text { форм }\end{array}$ & 4 & 34 & \\
\hline & фреон - 113 & 37,5 & 34 & \\
\hline & 0,25\% трипсин & 37 & 34 & \\
\hline & додецилсульфат натрия & 22 & 34 & \\
\hline \multirow{3}{*}{$\begin{array}{l}\text { J.Kisary, D.Derzsy, } \\
1974\end{array}$} & температура & 60 & \multirow{3}{*}{60 мин } & \multirow{3}{*}{ устойчив } \\
\hline & 20\% эфир, хлороформ & 22 & & \\
\hline & $\mathrm{pH} 3,0$ & 22 & & \\
\hline
\end{tabular}




\begin{tabular}{|c|c|c|c|c|}
\hline \multirow{5}{*}{$\begin{array}{c}\text { Г.А.Надточей с со- } \\
\text { авт., } 1975 \\
\text { Е.А.Петелина, 1976, } \\
1984\end{array}$} & эфир, хлороформ & 4 & \multirow{5}{*}{60 мин } & \multirow{5}{*}{ устойчив } \\
\hline & фреон - 113 & 37 & & \\
\hline & температура & 56 & & \\
\hline & 0,1\% дезоксихолат натрия & 37 & & \\
\hline & pH от 3,0 до 10,0 & 22 & & \\
\hline \multirow{4}{*}{ H.C.Hansen, 1980} & \multirow{3}{*}{ температура } & 50 & 34 & \multirow{3}{*}{ устойчив } \\
\hline & & 56 & 24 & \\
\hline & & 65 & 30 мин & \\
\hline & $\begin{array}{c}\text { 0,5-1,0\% раствор фор- } \\
\text { мальдегида }\end{array}$ & $\begin{array}{l}\text { во внеш. } \\
\text { среде }\end{array}$ & 15 мин & инактивир \\
\hline & г) аллантоисная вируссодер & кащая жид & OCTЬ & \\
\hline \multirow{5}{*}{$\begin{array}{c}\text { В.С. Фадин, } \\
\text { А.В.Куриленко, } \\
1981\end{array}$} & температура & 56 & 44 & устойчив \\
\hline & температура & 60 & 24 & инактивир. \\
\hline & 0,02-0,04\% формальдегид & 22 & $2-484$ & устойчив \\
\hline & 0,06\% формальдегид & 37 & 484 & инактивир \\
\hline & $\begin{array}{c}\text { 0,05-0,07 М гидроксила- } \\
\text { мин }\end{array}$ & 22 & $2-484$ & устойчив \\
\hline \multicolumn{5}{|c|}{ д) культуральная вируссодержащая жидкость } \\
\hline \multirow{4}{*}{$\begin{array}{c}\text { Б.Б.Трефилов, 1976, } \\
2000 \\
\text { А.О.Михайлов, } \\
2009\end{array}$} & температура & $56-60$ & 24 & устойчив \\
\hline & $\begin{array}{c}\text { 20\% эфир, } \\
\text { 10\% хлороформ }\end{array}$ & 4 & $1-44$ & устойчив \\
\hline & 0,1\% формальдегид & 37,5 & 244 & инактивир. \\
\hline & 0,1\% аминэтиленимин & 37,5 & 244 & инактивир. \\
\hline
\end{tabular}

\section{6. Антигенная специфичность и степень нейтрализации специфической антисывороткой}

Исследования о возможности существования антигенных вариантов парвовируса гусей до настоящего времени не получили подтверждения. Наряду с выяснением групповой принадлежности возбудителя ученые изучали антигенное родство штаммов, выделенных от больных гусят в разных странах, а также антигенную специфичность и их вариабельность.

Установлено, что парвовирус гусей представляет собой однородный в антигенном отношении вирус, претерпевающий лишь кратковременные изме- 
нения своей вирулентности (Л.М. Контримавичус, 1975a; С.H.Schettler, 1973). Однако имеются работы, в которых доказано, что в пределах одного и того же серологического типа могут встречаться штаммы вируса с различной антигенной специфичностью.

Так, сыворотка, полученная против французского штамма «Beta», нейтрализовала штаммы парвовируса гусей, выделенные в Голландии «Duth», Венгрии "В», Италии и СССР. Однако были отмечены некоторые биологические особенности отдельных штаммов. Штамм «Duth», прошедший 14 пассажей на гусиных эмбрионах, вызывал более интенсивный цитопатический эффект в культуре гусиных фибробластов, чем штамм «В», прошедший 51 пассаж на эмбрионах гусей (G.Dannacher et al., 1974).

C.H.Schettler (1971a, в) показал в РДП в геле отсутствие общего группоспецифического антигена вирусов инфекционного бронхита, ньюкаслской болезни, оспы, инфекционного ларинготрахеита, инфекционной бурсальной болезни, гриппа А и аденовируса с выделенным им парвовирусом гусей, а в реакции нейтрализации вирусами энцефаломиелита кур, гепатита уток и реовируса "2313». Вирус не нейтрализовался специфическими сыворотками к вирусу чумы уток и изолятам вируса «В» и «Н», выделенными от гусей.

N.V.Hanh (1974) сообщил о том, что существует тесное антигенное родство между двумя вьетнамскими и штаммом «В» парвовируса гусей.

По данным J.Kisary (1974); J.Kisary, D.Derzsy (1975) штаммы «H» и «B» (Венгрия), «Duth» (Голландия), “Beta» (Франция) и «ЛИ» (ССCP) в перекрестной реакции нейтрализации в культуре клеток имели антигенное родство. На основании физико-химических, морфологических и антигенных свойств штамм «В» был классифицирован как парвовирус гусей. В перекрестной реакции на гусиных эмбрионах и суточных гусятах не показано антигенного родства между штаммами «B» и «H» и в реакции серозащиты между штаммами «B» и «H».

При сравнительном изучении штаммов парвовируса уток «KPV», гусей "KLM» и аттенуированного штамма "ДР» в реакции серозащиты на гусятах J.Kisary, L.Zsak (1983) установили, что гусята, вакцинированные штаммом "ДР», показали 100\% защиту против штамма «KPV», но оказались незащищенными против штамма "KLM», а иммунизированные гусята двумя штаммами «KPV» и "ДР» были устойчивыми к штамму «KLM». Однако в перекрестной реакции нейтрализации в культуре клеток гусиных эмбрионов штаммы «KPV», «KLM» и «ДР» оказались антигенно родственными.

Л.М.Контримавичус (1975а), Д.Держи с соавт. (1975) установили антигенное родство между штаммами "ЛИ», "ДК», «Уфqа», "ВВ», «Roc», "Tata» парвовируса гусей в реакции нейтрализации. 
C.H.Schettler (1973) показал, что специфические сыворотки к штаммам "B», «H» и «Csontos» ингибировали штамм «SHM 319» (ФРГ), репродуцируемый в культуре клеток.

В.В.Малушко с соавт. (1976) сообщили об антигенном родстве штамма «B» в отношении изолятов, выделенных в Горьковской, Омской, Одесской областях и Башкирской АССР, в то время изолят вируса, выделенный в Курганской области, не имел родства.

Выделенный в Китае вирус имел антигенное родство с парвовирусом, который вызывал болезнь Держи в Венгрии и Вьетнаме (D.Y.Fang, Y.K.Wang, 1981).

В своей работе W.Peter (1985) констатировал, что исследуемые в перекрестной реакции нейтрализации штаммы «32», «17» и «51», выделенные в ГДР и штамм, используемый в вакцине «De-par-vac» антигенно родственны. Автор также показал ингибирующую активность гетерологичных сывороток к штаммам «CSSR», «Ungarn» и «Cairina» по отношению к исследуемым штаммам парвовируса.

При сравнительном изучении нуклеотидной последовательности изолята «PSV-31010» парвовируса, выделенного в Пенсильвании в 1997 г. из внутренних органов мускусных утят на эмбрионах и в культуре утиных фибробластов, с ранее выделенным изолятами парвовируса уток и гусей B.Poonia et al. (2006) показали, что они были идентичны лишь на 84,5 и 84,6\%, а родство их составило 99 и 95\% соответственно. Авторы сделали заключение, что изолят «PSV-31010» отличается от всех ранее выделенных парвовирусов и представляет собой новую группу парвовирусов птиц.

В работах Б.Б.Трефилова $(1976,2000)$ при изучении антигенного родства вакцинного "клона 6» штамма «П-75» и эпизоотических штаммов парвовируса, выделенных в различных географических зонах страны было показано, что «клон 6» нейтрализовался гомологической специфической сывороткой в больших титрах по сравнению с гетерологичными. По степени нейтрализации он характеризовался как An- клон вируса. В отношении эпизоотических штаммов «клон 6» оказался антигенно родственным. Однако имелись различия в антигенном родстве между полевыми штаммами парвовируса по степени нейтрализации специфическими антисыворотками.

Отмеченные некоторые антигенные различия между штаммами свидетельствуют об использовании неодинаковых методик реакции нейтрализации при изучении антигенного родства. Поэтому С.H.Schettler (1971a); J.Kisary (1974) рекомендовали выяснить особенности биологических систем, в которых проводятся изучения антигенных свойств штаммов возбудителя. 


\section{7. Способность к репродукции в различных культурах клеток}

За последнее время для культивирования вирусов широко используются различные культуры клеток, выращенные in vitro.

Впервые о способности парвовируса репродуцироваться в культуре клеток почек гусиных эмбрионов (ПЭГ) сообщили Л.М.Контримавичус, А.Д.Майборода (1968). Цитопатический эффект (ЦПЭ) обнаруживали во 2-ом пассаже вируса, он выражался в округлении клеток с последующим отделением их от стекла. Позже репликацию вируса в тканевых культурах изучали Л.М.Контримавичус (1970а, 1974а); М.В.Капитанаки с соавт. (1971); C.H.Schettler (1973); J.Kisary, D.Derzsy (1974) и другие.

Так, штамм «SHM 319» парвовируса гусей, культивируемый в клетках гусиных эмбрионов, был адаптирован культурам клеток почек и печени эмбрионов гусей, но с меньшим ЦПЭ (С.H.Schettler, 1973).

G.Fenske et al. (1975) сообщили об адаптации полевого вируса к культуре ПЭГ после проведения 4 слепых пассажей.

Наиболее удобной и распространенной моделью для культивирования парвовируса гусей явилась первично-трипсинизированная однослойная культура клеток гусиных эмбрионов (Г.А.Надточей с соавт., 1975; Л.М.Контримавичус, 1975а; К.П.Комиссаров, 1976; Р.Т.Пожалова, 1976; A.В.Суворов, 1986; D.Derzsy, 1971; J.Kisary, 1974; G.Dannacher et al., 1974; R.E.Gough et al., 1981; J.Kisary, L.Zsak, 1983).

J.Kisary, D.Derzsy (1974, 1975), R.E.Gough et al. (1981) удалось адаптировать вирусные штаммы «B», «H», "LB», изолированные из органов павших гусят, к культуре клеток гусиных эмбрионов с выраженным цитопатогенным действием, характеризующимся округлением клеток исчезновением цитоплазмы и образованием эозинофильных ядерных включений типа А. ЦПД наступало через 36 часов и достигало максимального инфекционного титра через 60 часов после заражения. В результате серийных пассажей штамма «B» был получен аттенуированный вариант (мутант) «BAV», используемый в дальнейшем как вакцинный штамм (J.Kisary, 1977; J.Kisary et al., 1978).

Культуру клеток готовили из 11 - 14-суточных гусиных эмбрионов. С концентрацией 3 - 5 • $10^{5}$ клеток в 1,0 cм3 (G.Dannacher et al., 1974), $4-6 \cdot 10^{5}$ клеток в 1,0 $\mathrm{cm}^{3}$ (J.Kisary, 1974), 5 - 7,5 - 10 клеток в 1,0 $\mathrm{cm}^{3}$ (Г.А.Надточей с соавт., 1975), 1 - $10^{6}$ клеток в 1,0 см33 (J.F.Bouquet et al., 1981). При увеличении концентрации клеток в суспензии урожай вируса снижался (J.Kisary, 1974). Авторы сообщили, что монослой клеток формировался через 2 - 3 суток и в это же время проводили заражение культуры клеток парвовирусом гусей. 
G.Dannacher et al. (1974) показали, что с возрастом чувствительность культуры к вирусу становится меньше. Так, 20-суточная культура клеток была не чувствительна к вирусу.

Впервые для парвовируса гусей J.Kisary (1974) установил корреляцию между указанными параметрами. Наивысший инфекционный титр вируса был отмечен при внесении его в клеточную суспензию или через 4 часа после посева клеток. В случае использования 24-часовых культур титр снижался на 1,0 lg - и резко падал, если заражали культуру через 48 часов после посева.

Вирус, пассируемый в культуре клеток гусиных эмбрионов, был адаптирован к культуре фибробластов эмбрионов мускусных уток (G.Dannacher et al., 1974, N.V.Hanh, 1974). ЦПЭ вируса появлялся после проведения 2 - 3 слепых пассажей. Время необходимое для полного разрушения монослоя утиных фибробластов было на 2 - 3 суток дольше, чем гусиных, при одинаковом ЦПЭ и титре вируса $10^{6}-10^{7}$ ЦП

ЦПД вируса энтерита выражалось в округлении клеток, появлении зернистости в цитоплазме, приводившие к деструкции клеток монослоя (Л.М.Контримавичус, А.Д.Майборода, 1968; Г.А.Надточей с соавт., 1975), наряду с этим к образованию синцития (Р.Г.Пожалова, 1976) и симпластов (А.В.Суворов, 1982; Е.А.Петелина, 1984).

К.П.Комиссаров (1976) МФА обнаруживал антиген парвовируса гусей преимущественно в цитоплазме (перинуклеарной зоне) клеток гусиных эмбрионов, где появлялись точечные зерна яркого желто-зеленого цвета. Повидимому, автор констатировал позднюю стадию репликации вируса и объясняет их появление выходом вирусных частиц из ядра клетки.

C.H.Schettler (1973) отмечал базофильные внутриядерные и эозинофильные цитоплазматические тельца - включения, единичные клеточные некрозы, образование синцития. Спустя 2 - 3 суток после появления ЦПЭ наблюдалась дегенерация этих клеток. При добавлении 5-йод-2-дезоксиуридина к поддерживающей среде ЦПэ полностью исчезал.

ЦПД вируса в культурах клеток гусиных эмбрионов и эмбрионов мускусных уток характеризовался поражением ядер, в которых происходила маргинация хроматина, появлялись гранулярные эозинофильные зоны. Позже зоны становились базофильными, охватывая все ядро, вслед за этим наступал пикноз ядра. Поражение цитоплазмы следовало за нуклеопатическими изменениями. Клетка округлялась, сморщивалась и дегенерировала (G.Dannacher et all., 1974). Методом флуоресцирующих антител авторы отмечали изменения ядрышек, которые постепенно перемещались к маргинальному хроматину, приобретая зеленое свечение, интенсивность которого усиливалась. Цитоплазма сжималась вокруг ядра и в ней появлялась окрашенные в зеленый цвет гранулы. Зеленое свечение цитоплазмы в конечной стадии инфекцион- 
ного процесса авторы объясняли разрывом оболочки ядра и выходом вирусных частиц в цитоплазму.

По данным Г.А.Надточего с соавт. (1975), выделенные им штаммы вируса гусей вызывали в культуре клеток гусиных эмбрионов ЦПЭ деструктивного типа на 5 - 6 сутки, с увеличением числа пассажей ЦПэ наступал уже через 2 - 5 суток (G.Dannacher et al., 1974). Культуральный вирус сохранял патогенные свойства для гусиных эмбрионов и гусят (Р.Г.Пожалова, 1976).

C.H.Schettler (1972) предложил для культивирования вируса энтерита первично-трипсинизированные и субкультуры клеток гусиных эмбрионов.

А.В.Суворов $(1982,1986)$ культивировал штаммы «Ж», «БК», «Уфра» вируса энтерита гусей в культуре клеток гусиных эмбрионов. Штаммы вызывали однотипный ЦПЭ (рыхление монослоя, округление клеток, вакуолизация цитоплазмы, перемещение ядер к периферии клетки, образование симпластов). В ядрах отмечались маргинация хроматина и образование эозинофильных включений, окруженных светлым ореолом.

Чувствительность субкультур штамма «КЭГ №1» к вирусу энтерита гусей и характер его ЦПД в динамике через 24, 72 и 120 часов после заражения изучала Е.А.Петелина (1984). Единичные изменения в субкультуре клеток при исследовании цитологических препаратов были обнаружены через 24 часа. Ядрышки, сливаясь в одно, приобретали палочковидную форму и увеличивались в размере. В ядрах происходила маргинация хроматина в виде глыбок или узкой полоски. Через 72 часа в ядрах фибробластоподобных клеток появлялись плотные включения, в монослое возникали симпласты, а ядра имели меньшие размеры. На 5 сутки происходил пикноз ядра, эффект симпластообразования усиливался, отмечена дегенерация клеток монослоя. Характер ЦПД вируса, как в первично-трипсинизированной культуре, так и в субкультуре, был одинаковым. Различий в характере деструктивных изменений, вызванных вирулентным или аттенуированным штаммами вируса энтерита, автором не установлено. Субкультуры имели исходную чувствительность к вирусу, его титр составлял 4,65 - 5,2 lg ТЦД $/ \mathrm{cm}^{3}$.

J.Kisary, L.Zsak (1983) сообщили об индуцировании вирусом в культуре клеток гусиных эмбрионов негативных колоний. Вирулентный штамм вируса образовывал мелкие бляшки с четкими краями, а аттенуированный - крупные бляшки с нечеткими краями. Авторы пришли к заключению, что размер и морфология бляшек могут быть использованы как генетический маркер при идентификации и дифференциации вирулентных и ослабленных штаммов.

J.Roszkowski et al. (1982) показали чувствительность клеток гусиных эмбрионов к штамму «В» вируса болезни Держи иммуноферментным методом. Антиген обнаруживали через 48 часов в ядрах клеток в виде темно-коричне- 
вых гранул, количество и размер их варьировала. Через 72 часа количество гранул значительно увеличивалось, и были обнаружены в цитоплазме, и на более поздних стадиях (96-120 часов) ЦПэ препятствовал выявлять локализацию антигена.

W.Peter (1985) адаптировал, выделенные в период эпизоотий в ГДР, штаммы парвовируса к культуре клетки гусиных эмбрионов, которые накапливались в титрах $10^{4}-10^{5}$ ТЦД больший выход вируса при заражении культуры через 2 часа после посева клеточной суспензии. ЦПЭ наступает спустя 48 часов и усиливается к 4 - 6 суткам, достигая полной деструкции клеток монослоя. Оптимальная температура культивирования была $37-38^{\circ} \mathrm{C}$.

Штаммы парвовируса гусей в культурах клеток L, Vero, почек куриных эмбрионов (Е.А.Петелина, 1984) и почек гусиных эмбрионов, куриных фибробластов и Vero (W.Peter, 1985) не вызывали ЦПД в клетках.

Способность парвовируса гусей к репликации в перевиваемых клетках (Нер-2, L, BHK-21, HeLa, амнион человека) изучали B.В.Малушко с соавт. (1977). Авторы установили цитопатогенную активность вируса, но накопление вируса в них было разным. ЦПЭ характеризовался появлением отдельных округлых клеток и отслоением их от стекла.

Используя метод тканевых культур, были изучены цитопатогенная и бляшкообразующая активности и способность к репликации эпизоотических штаммов вируса энтерита при различных температурах, был селекционирован апатогенный вакцинный «клон 6» штамма «П-75» парвовируса гусей (Б.Б.Трефилов, 1989,2000; Б.Б.Трефилов, И.В.Щеглова, 1989; Б.Б.Трефилов, А.О.Михайлов, 2009).

Авторы установили, что вирулентные и аттенуированные штаммы вируса индуцировали острую форму вирусной инфекции в культурах фибробластов и эпителия почек гусиных эмбрионов. Репликация их сопровождалась ЦПД. Ранним проявлением ЦПД в клетках явилось увеличение размеров их ядер. Характерным признаком ЦПД были округление клеток, появление зернистости в цитоплазме, разрыв монослоя. Затем образовывались многоядерные (симпластоподобные) клетки с внутриядерными включениями, интенсивно окрашивавшимися гематоксилином. На последней стадии культивирования наступала полная дегенерация клеток. Максимальное накопление вируса составляло

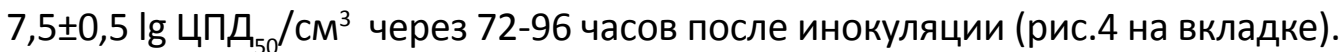

Вирулентные штаммы вируса индуцировали образование под питательным агаром мелких (1-2 мм) по морфологии 2 типов бляшек (STC-, Plt и PIC) в титрах $4 \cdot 10^{4}-1.5 \cdot 10^{5} \mathrm{BOE} / \mathrm{cm}^{3}$. 
Аттенуированный «клон 6» вируса вызывал формирование мелких однотипных по морфологии бляшек. (STC- и PIC), при эксперементальных пассажах признаки оставались стабильными. «Клон 6» потерял патогенность

для гусиных эмбрионов и гусят. В настоящее время «клон 6» парвовируса используется как вакцинный штамм для производства живой и инактивированной вакцин против парвовирусной инфекции гусей (патент РФ № 1499917, 1993).

Способность «клона 6» к репродукции при пониженной температуре $\left(34^{\circ} \mathrm{C}\right)$ авторы изучали в культуре фибробластов гусиных эмбрионов. Вирус вызывал аналогичное ЦПД, какое при температуре культивирования $37^{\circ} \mathrm{C}$.

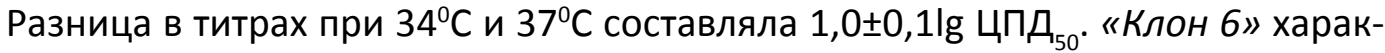
теризовался как $\mathrm{Rct}_{34}{ }^{\mathrm{TC}+}$ штамм.

Авторы обнаружили определенную корреляцию генетических признаков размера, морфологии бляшек, $\operatorname{Rct}_{34}{ }^{\mathrm{Tc}+}$ и патогенности в процессе экспериментов.

Приведенные литературные данные показывают способность вируса энтерита гусей к репродукции в гомологичных культурах клеток.

\section{ГЛАВА 3.}

\section{Парвовирусная инфекция гусей}

\section{1. Хронологическая справка, распростарнение и ущерб, причиняемый этой болезнью}

Парвовирусная инфекция (вирусный энтерит, болезнь Держи) гусей Enteritis virosa anserculorum - острая, контагиозная болезнь молодняка гусей и мускусных уток, характеризующаяся преимущественным поражением желудочно-кишечного тракта и других паренхиматозных органов и сопровождающаяся высокой смертностью (Л.М.Контримавичус, 1971, 1978; В.В.Малушко, 1982; Б.Б.Трефилов, 1990, 2000).

О заболевании птиц вирусным энтеритом первые сообщения появились одновременно во многих странах. В СССР болезнь наблюдали Л.М.Контримавичус с соавт. (1966), Венгрии - D.Derzsy et al. (1966), Голландии - S.A.M.Cleef, J.T.van Miltelnburg (1966) у гусят и утят мускусных уток в возрасте 1-30 суток. Они доказали инфекционную природу болезни и описали ее, назвав разными синонимами.

Распростронение. Так, в соответствии с инфекционной этиологией, клиническимипризнаками ипатоморфологическими изменениями, болезнь была названа «инфекционным» вирусным энтеритом гусят (Л.М.Контримавичус 
с соавт., 1966; Л.М.Контримавичус, 1968; М.В.Капитанаки с соавт., 1970; В.С.Фадиным, Л.Дедковой, 1970; В.Ф.Макогоном с соавт., 1974; Н.М.Музика с соавт., 2010), чумой гусей (S.A.M.Cleef, J.T.van Miltenburg, 1966; M.J.Krauss, 1965), вирусным гепатитом гусей (C.H.Schettler 1971a, в, 1972, 1973), так называемой «инфлюэнцией» гусей (D.Derzsy et al., 1966, 1969; L.Csontos, M.Csatari, 1967a, 19676, 1967с), вирусной болезнью гусят (M.Coudert et al., 1972; M.Coudert 1973), новой болезнью гусят (G.W.Crighton, G.T.Wilkinson, 1970), инфекционным миокардитом (G.Mandelli et al., 1971), гепатонефрит-асцитом (Ch. Labie, 1972), болезнью Держи (J.Kisary et al., 1977). Однако в настоящее время в зарубежной литературе большинство исследователей называют это заболевание болезнью Держи, в честь автора, впервые детально описавшего его (J. Kisary, 1977; H.C.Hanson, 1980; D.Y.Fang, Y.K. Wang, 1981; R.E. Gough et al. 1981).

Вслед за описанием парвовирусной болезни гусей в ФРГ (H.Krauss, 1965) его стали регистрировать и в других странах:

в Венгрии - D.Derzsy et al. (1966), L.Csontos, M.Csatari (1967a);

в Англии - G.W.Crighton, G.T.Wilkinson (1970);

во Франции - Ch.Labie (1972);

в Израиле - Y.Samberg et al. (1972);

во Вьетнаме - N.V.Hanh (1974);

в Дании - Н.C.Hansen (1979);

в Чехословакии - B.Dvorak, D.Dvorakowa (1980);

$\sim$ В ГДР - W.Peter (1985), R.Kokles (1985).

В СССР Л.М.Контримавичус с соавт. $(1966,1968)$ впервые сообщили об этой болезни под названием вирусный энтерит гусей. Они наблюдали его в 1963-65 г.г. в Горьковской и Куйбышевской областях.

Позднее вирусный энтерит гусят установили в Московской, Омской областях (Л.М.Контрамавичус, 1968, 1969), в Краснодарском крае и Кубани (М.В.Капитанаки с соавт., 1971а,б), в Новосибирской, Омской, Кокчетавской, Курганской областях, Башкирской АССР (В.С.Фадин, 1972, 1973, 1975; В.Г.Руднякова, 1976), в Крымской (В.Ф.Макогон с соавт, 1974), в Одесской (В.В.Малушко с соавт., 1975).

Экономический ущерб. Вирусный энтерит причиняет гусеводческим хозяйствам значительный экономический ущерб. Болезнь протекает в виде эпизоотии и смертность гусят в возрасте 1-30 суток, по некоторым данным, составляет 20-100\% (Л.М.Контримавичус с соавт., 1966; Л.М.Контримавичус, 19706, 1971, 1972; В.С.Фадин, 1973а, 1977, 19796; В.Ф.Макогон с соавт., 1974; N.V.Hanh, 1974; А.Ф.Бондаренко, М.В.Капитанаки, 1975а, б, в; М.В.Крылов, A.Б.Терюханов, 1975; C.H.Schettler, 1971a; B.Dvorak, D.Dvorakowa, 1980; R.Kokles et al., 1985; G.Fenske et al., 1974, 1975; J.Hoekstra, T.Smit, 1973; W.Peter, 
1985; M.Coudert et al., 1972; D.Derzsy, 1971, 1973a, б; H.Krauss, 1965; Z.Temesi, 1966).

Ущерб при этой болезни обусловлен потерями в результате гибели гусят, недополучением прироста живой массы переболевших и их преждевременной выбраковкой, а также нарушением селекционно-племенной работы. Оценивая общий экономический ущерб по этим показателям, В.С.Фадин (19796) считает, что на 100 птиц он составляет 596,6 рублей. Переболевшая птица теряет в весе, снижается эффективность ее откорма.

Von K.Ziedler et al. (1978) отмечали, что заболеваемость мускусных утят (Cairina moschata) в возрасте 12-21 суток составляла 60-95\%, а гибель их 20$60 \%$. На откорме переболевшие утята-бройлеры не достигали убойного веса, и снижалась эффективность их откорма. Так, к 70-77 суткам выращивания птица теряла живую массу на 1,0 - 1,1 кг против нормы, снижались убойные качества мяса на 20-30\%.

Если борьба с вирусным энтеритом ведётся недостаточно эффективно, хозяйство может стать стационарно неблагополучным по этой болезни, так как среди последующего поколения гусят, вследствие длительного вирусоносительства переболевшей птицы, могут возникать вспышки заболевания. Возникает необходимость в дополнительных расходах на проведение лечебно-профилактических и ветеринарно-санитарных мероприятий.

\section{2. Эпизоотологические данные болезни}

На основе теоретического изучения заразных болезней возможно своевременное и правильное осуществление профилактических мероприятий и мер борьбы с распространением инфекционной болезни, что представляет главную практическую задачу эпизоотологии (М.С.Ганнушкин, 1965).

Массовые вспышки вирусного энтерита гусей регистрировали преимущественно в весенне-летний период, с марта-апреля по июль месяц (Л.М.Контримавичус, 1968, 1972; М.В.Капитанаки с соавт., 1971а; В.Ф.Макогон с соавт., 1974; D.Derzsy, 1967; I.Doman, 1970; M.Coudert et al., 1972; Y.Samberg et al., 1972), то есть в течение всего преиода инкубации гусиных яиц.

В.С.Фадин, Б.И.Лапин (1974), В.С.Фадин, (1977) считают, что выраженной сезонности при этом заболевании нет, что подтверждено появлением вспышек вирусного энтерита в неблагополучных хозяйствах с круглогодовой инкубацией гусиных яиц.

Л.М.Контримавичус (1968); D.Derzsy (1971); Y.Samberg et al. (1972), J.Kisary et al. (1975a, в), отмечали двухгодичную цикличность болезни, что связано с уровнем пассивного иммунитета, передающегося выведенному потомству.

Существует определенная корреляция между яйценоскостью и восприимчивостью гусят к инфекции: молодняк высокояйценоской горьковской по- 
родной группы гусей менее устойчив к экспериментальному заражению, чем птица серой степной породы, характеризующейся более низкой яйценоскостью (Л.М.Контримавичус, 1970б).

Вирусный энтерит протекает в виде эпизоотии и приносит большие потери. Гибель гусят составляет 20 - 100\% (Т.Монашон, 1966; Л.М.Контримавичус, 1968; 19706; А.Ф.Бондаренко, М.В.Капитанаки, 1975а; Krauss, 1965; С.А.М. Cleef, van J.T.Miltenburg, 1966; Z.Temesi, 1966; I.Doman, 1970; T.Suveges, I.Szencsenyi, 1970; C.H.Schettler, 1971a,г; Y.Samberg et al., 1972; M.Coudert et al., 1972), причем гибель в начале сезона выращивания бывает обычно невысокой (В.С.Фадин, 19756; 1977), а затем увеличивается в каждой вновь выводимой партии, достигая в некоторых из них 100\% (Л.М.Контримавичус, 1968; Л.М.Контримавичус с соавт., 1966; М.В.Капитанаки с соавт., 1970; А.Ф.Бондаренко, М.В.Капитанаки, 1975а; M.Coudert et al., 1972).

Заболеванию подвергаются обычно гусята в возрасте 1 - 30 суток (Л.М.Контримавичус, 19706, 1971, 1972, 1974а,б; В.С.Фадин, 1973а, 1975б, 1979а; В.Ф.Макогон о соавт., 1974; А.Ф.Бондаренко, М.В.Капитанаки, 1975а; М.В.Капитанаки, Л.Д.Чечула, 1976; В.В.Малушко с соавт., 1980; H.Krauss, 1965; S.A.M.Cleef, van J.T.Miltenburg, 1966; I.Doman, 1970; D.Derzsy, 1968, 1973; S.Bernath, G.Pethes, 1971; M.Coudert et al., 1972; N.V.Hanh, 1974; J.Kisary, D.Derzsy, 1974; B.Dvorak, D.Dvorakowa, 1980 ). По данным многих авторов (Л.М.Контримавичус, 1968, 1970б; М.В.Капитанаки с соавт., 1970; А.Ф.Бондаренко, М.В.Капитанаки, 1975a; G.Dannacher et al., 1972; Y.Samberg et al., 1972) наиболее восприимчивы гусята 5-8 - суточного возраста. Наибольшая смертность отмечена на 10 - 16 сутки (R.Kokles et al., 1985).

Заболевание гусят в хозяйствах в возрасте 20 - 45 суток и старше вирусным энтеритом наблюдали Л.М.Контримавичус (19706; 1973), В.В.Малушко с соавт., (1980), I.Doman (1970); C.H.Schettler (1971в); H.C.Hansen (1980); D.Y.Fang, Y.K.Wang (1981); однако экспериментальное заражение вирусом гусят старше 30-суточного возраста воспроизвести не удавалось (В.С.Фадин, Б.И.Лапин, 1974; В.С.Фадин, 1977; Б.Б.Трефилов, 1996,2000; S.Bernath, G.Pethes, 1971; H.C.Hansen, 1980).

Вирусным энтеритом болеют дикие виды гусят - канадские и «снеговые», а также утята мускусных уток в возрасте до 30 суток (Л.М.Контримавичус, 1975а; Л.М.Контримавичус с соавт., 1980; C.H.Schettler, 1971a; J.Hoekstra et al., 1973).

Основными факторами в восприимчивости гусят к вирусу являются возраст птицы, наличие пассивного материнского иммунитета и факторы неспецифической резистентности (В.С.Фадин, 1977; А.В.Суворов, 1986; G.Fenske et al., 1974).

Ряд авторов (Л.М.Контримавичус с соавт., 1966; Л.М.Контримавичус, 1970б; А.Ф.Бондаренко, М.В.Капитанаки, 1975а; Б.Б.Трефилов, 1996; S.Bernath, F.Szalai, 1970; M.Coudert et al., 1972) отмечали высокую контагиозность болезни, что подтверждено ими в опытах по контактному заражению птицы. 
Л.М.Контримавичус (1969); M.Coudert et al. (1973) чаще наблюдали острое и подострое течение болезни у 1 - 4 - недельных гусят, реже сверхострое (M.Coudert et al., 1972), а иногда хроническое. M.Coudert et al. (1974) сообщали, что у птицы в возрасте от 4 недель до 3 месяцев заболевание характеризуется острым и хроническим геморрагическим синдромом.

Невосприимчивыми к вирусу энтерита при экспериментальном заражении оказались утята, в том числе пекинской и хаки-кембеллской пород, цыплята, индюшата и взрослые гуси (Л.М.Контримавичус, 19746; Б.Б.Трефилов , 1996; J.Hoekstra et al., 1973; J.Kisary, D.Derzsy, 1974; G.Fenske et al., 1975; H.C.Hansen 1980; R.E.Gough et al., 1981), а также лабораторные животные (В.С.Фадин, 19756; Б.Б.Трефилов, 1976). Однако по данным Б.Б.Трефилова (1976) эпизоотические штаммы вируса вызывали гибель мышей-сосунов линии СC57Br с патологоанатомическими изменениями во внутренних органах, из которых автор выделил вирус на гусиных эмбрионах.

При вирусном энтерите авторы (В.С.Фадин, 1975, 1977; В.С.Фадин с соавт., 1977; D.Derzsy, 1971; M.Coudert et al., 1972, 1973; H.C.Hansen, 1980) наблюдали длительное вирусоносительство переболевшими гусями, которые могут быть источником возбудителя болезни.

По данным многих исследователей (Л.М.Контримавичус, 1968, 1970а, 1972; М.В.Капитанаки с соавт., 1970; Л.М.Контримавичус с соавт., 1975; А.Ф.Бондаренко, М.В.Капитанаки, 1975а; М.В.Крылов, А.Б.Терюханов, 1975, 1966; Б.Б.Трефилов, 1996; I.Szencsenyi, 1967, 1971; D.Derzsy, 1967; T.Suveges, I.Szencsenyi, 1970; Y.Samberg et al., 1972; W.Peter, 1985)источником возбудителя является больная и переболевшая птица, которая остается вирусоносителем. Факторами передачи являются трупы, инфицированные корм, вода, воздух, инвентарь, оборотная тара, транспорт. Механическими переносчиками могут быть обслуживающий персонал, дикая птица, грызуны.

Передача вируса при этой болезни осуществляется трансовариальным путем (Л.М.Контримавичус, 1970; А.Ф.Бондаренко, 1972; I.Szencsenyi, 1967; C.H.Schettler, 1972; D.Derzsy, 19736; H.C.Hansen, 1980; W.Peter, 1985), а заражение гусят происходит алиментарным, аэрогенным путями (Л.М.Контримавичус с соавт., 1968; Л.М.Контримавичус, 1971, 1972; А.Ф.Бондаренко, М.В.Капитанаки, 1975; В.С.Фадин, 1975; 1977; H.C.Hansen, 1980) и через поврежденную кожу (Л.М.Контримавичус, 1970а; Б.Б.Трефилов, 2000).

Предрасполагающими факторами для распространения болезни в хозяйствах являются неудовлетворительное кормление птиц, особенно недостаток в кормах витаминов A, группы B, скармливание несвежей зелени, скученное содержание и недостаточная вентиляция помещений, а также несоблюдение необходимого санитарно-гигиенического режима кормления и содержания (Л.М.Контримавичус, 1970а; M.Coudert et al., 1973; A.Vuillaume et al., 1982). 
При изучении эпизоотологических особенностей парвовирусной инфекции гусей в 67 гусеводческих хозяйствах, ИПС и частном секторе было установлено, что болезнь в форме моноинфекции протекает в 60\% случаев, а как в форме смешанной инфекции с другими инфекционными болезнями в 40\% (сальмонеллезом, аспергиллезом, колибактериозом, кокцидиозом, пастереллезом и нейссериозом). Особенностью клинического проявления смешанной инфекции является острое течение инфекционного процесса с высокой смертностью гусят в течение 1-2 суток (В.В.Малушко с соавт.1983; Б.Б.Трефилов, 1996, 1998, 2000). Авторы экспериментально и в производственных условиях изучали возрастную восприимчивость гусят. Данные исследований показали, что наибольшая смертность была у гусят в 2-5 - суточном возрасте $(86,4-88,2 \%)$, в 9-15 - суточном возрасте гибель уменьшилась в 2,0-2,5 раза, а в 17-20 - суточном возрасте она составила 5-7\%. Гусята старше 20 суток были слабо восприимчивы к заражению парвовирусом (табл. 3).

Анализ учета смертности гусят по выводам в неблагополучных по парвовирусной инфекции хозяйствах показал, что она была относительно высокой уже с 2-3 вывода (8,8-21,3\%). К середине периода инкубации смертность увеличивалась до 71,9\% и достигала к его окончанию 80-100\%. Увеличение гибели гусят в каждой последующей партии, по-видимому, происходило в результате накопления возбудителя во внешней среде и усиления его вирулентности.

Таблица 3

Восприимчивость гусят к парвовирусу в зависимости от возраста

\begin{tabular}{|c|c|c|c|c|}
\hline \multirow{2}{*}{$\begin{array}{c}\text { Штамм и доза } \\
\text { вируса }\end{array}$} & \multirow{2}{*}{$\begin{array}{c}\text { Возраст гусят, } \\
\text { суток }\end{array}$} & \multirow{2}{*}{$\begin{array}{c}\text { Количество } \\
\text { гусят }\end{array}$} & \multicolumn{2}{|c|}{ Смертность гусят } \\
\hline & & & голов & $\%$ \\
\hline \multirow{8}{*}{$\begin{array}{c}\text { «П-75» } \\
1000 \text { эл }{ }_{50} / 0,2 \mathrm{~cm}^{3}\end{array}$} & $2-3$ & 66 & 57 & 86,4 \\
\hline & 5 & 17 & 15 & 88,4 \\
\hline & 9 & 24 & 10 & 41,7 \\
\hline & 15 & 26 & 9 & 34,6 \\
\hline & 17 & 40 & 2 & 5,0 \\
\hline & 20 & 42 & 3 & 7,1 \\
\hline & 25 & 20 & 0 & 0 \\
\hline & 30 & 20 & 0 & 0 \\
\hline
\end{tabular}

Наиболее важным в эпизоотической цепи является трансовариальная передача вируса. В опытах на чувствительных гусятах и в культуре клеток были выделены и идентифицированы в РДП в агаровом геле изоляты вируса 
из патологического материала павших гусиных эмбрионов 23-25 - суточной инкубации в 6-ти случаях (Б.Б.Трефилов, 1996).

Таким образом, широкому распространению парвовируса способствуют его высокая устойчивость к воздействию физико-химических факторов, длительное персистирование в организме переболевшей птицы, высокая контагиозность, трансовариальная передача, а также несовершенная технология выращивания. Комплектование хозяйств племпродукцией без учета эпизоотического благополучия по данной болезни, которое определяется качеством организации и проведения специальных противоэпизоотических и общих ветеринарно-санитарных мероприятий, также способствует распространению парвовируса.

\section{3. Патогенез}

При электронномикроскопическом изучении изменений ультраструктуры энтероцитов и гепатоцитов, вызванных вирулентным штаммом парвовируса гусей при парэнтеральном заражении гусят в дозе $1000 \ni^{\prime} Д_{50}$ Е.А.Петелина $(1983,1984)$ установила инкубационный период болезни, который составил 36 часов. Через 48 часов после инокуляции автор отмечал в энтероцитах редукцию щеточной каймы, набухание митохондрий. Цитоплазма гепатоцитов была наиболее вакуолизированной, в них выявляли крупные жировые включения. Через 72 часа происходило углубление патологического процесса в ультраструктуре ядер, а в клетках паренхимы печени развивались диффузные некробиотические процессы. Через 96 часов в энтероцитах патология обнаруживалась, главным образом, в структуре цитоплазматических органоидов, реже в ядре, в гепатоцитах происходили наиболее глубокие процессы некробиоза. Через 120 часов в энтероцитах патологические процессы носили глубокий деструктивный характер вплоть до необратимого состояния на уровне всех органоидов, что приводило к некрозу и нарушению целостности (десквамации) эпителиального покрова слизистой оболочки кишечника. В одних гепатоцитах развивались некробиотические процессы, а другие были подвержены жировой дистрофии.

Таким образом, патологические изменения, развивающиеся в печени и кишечнике при парвовирусной инфекции гусей, свидетельствуют об одновременной репликации вируса в эпителиальных клетках указанных органов.

Исследования ряда авторов (А.В.Акулов, Л.М.Контримавичус, 1975; B.C.Фадин с соавт., 1973; Z.Nagy, D.Derzsy, 1968; C.H.Schettler, 1971в, д, е; 1973; K.Ziedler et al., 1978; W.Peter, 1985; V.Bergmann, 1987) свидетельствуют, что репликация парвовируса сопровождается глубокими дегенеративными изменениями в клетках паренхиматозных органов (сердце, печени, поджелудочной железы, почек), желудочно-кишечного тракта, нервной и мышечной тканях. 


\section{4. Клинико-патоморфологические признаки}

Клинические признаки при парвовирусной инфекции описаны в разных странах и имеют много общего.

Инкубационный период длится от 2 - 8 (Л.М.Контримавичус, 1968) до 14 суток (J.Hoekstra et al., 1973), а при экспериментальном заражении он составлял 3 - 7 (В.С.Фадин с соавт., 1973) или 4 - 12 суток (Л.М.Контримавичус с соавт., 1980). При вспышках в последующих партиях гусят неблагополучного хозяйства он сокращался до 5 суток (Л.М.Контримавичус, 1968; 1972; В.С.Фадин с соавт., 1973).

У больных гусят исследователи отмечали общее угнетение, отсутствие аппетита, малую подвижность, сонливость, диарею (Л.М.Контримавичус, 1968; М.П.Кондаков, В.С.Фадин, 1973; В.Ф.Макогон с соавт., 1974; S.A.M.Cleef, van J.T.Miltenburg, 1966; D.Derzsy, 1967; G.W.Crighton, G.T.Wilkinson, 1970; M.Coudert et al., 1972; J.Hoekstra, H.Yadin, 1973; G.Fenske et al., 1975).

Кроме общих признаков наблюдали сужение глазной щели, конъюнктивит, слезотечение, истечение из носа, одышку, атаксию (D.Derzsy, 1967, H.C.Hansen, 1980), жажду и лихорадку (М.П.Кондаков, В.С.Фадин, 1973; M.Coudert et al., 1972), покраснение кожи (A.A.S.Ahmed, 1973), выпадение пуха и пера в области шеи и спины (D.Derzsy, 1967; C.H. Schettler, 1971в) (рис.5 на вкладке).

При некоторых эпизоотиях болезнь сопровождалась развитием нервных явлений (возбуждение, некоординированные движения, запрокидывание головы на спину, парезы) (А.Б.Байдевлятов, 1966; В.Ф Макогон с соавт., 1974; И.И.Паникар, Б.И.Белицкий, 1971; D.Derzsy, 1967; H.C.Hansen, 1980).

Ряд авторов (Л.М.Контримавичус с соавт., 1966; S.A.M.Cleef, van J.T.Miltenburg, 1966; M.Coudert et al., 1972; Ch.Labie, 1972) наблюдали острое и подострое течение болезни. При остром течении болезнь протекала несколько часов, реже 2 - 3 суток, и приводила к гибели гусят (В.Ф.Макогон с соавт., 1974; В.Ф.Макогон, 1975). Клинические признаки характеризовались угнетением, снижением или полным отсутствием аппетита, повышенной жаждой, слабостью, скучиванием, стремлением к источнику тепла и быстрой гибелью заболевших птиц.

При подостром течении больная птица плохо поедала корм, была малоподвижна, стояла, сгорбившись с полузакрытыми глазами. Наблюдался понос, помет беловатого цвета с пленками фибрина (М.В.Капитанаки с соавт., 1970; В.Ф.Макогон, 1979; H.Krauss, 1965, 1967; C.H.Schettler, 1971a; Y.Samberg et al., 1972; R.Kokles et al., 1985), а иногда с примесью крови (Л.М.Контримавичус, 1968; Л.М. онтримавичус с соавт., 1966; В.С.Фадин, 1972; 1979а; Е.А.Петелина, 1983, 1984). Подострое течение наблюдается среди гусят в возрасте 12 - 21 суток (Л.М.Контримавичус с соавт., 1966; Л.М.Контримавичус, 1968). 
По данным K.Ziedler et al. (1978) парвовирусная инфекция наблюдалась у мускусных утят (Cairina maschata) в 1973 году в хозяйствах ГДР.

Первые симптомы заболевания появлялись на 8 - 12 сутки, которые характеризовались отказом от корма, нарушением движения, конъюнктивитом, диареей, а между 12 - 21 сутками отмечались поражения дыхания, нервные явления (судороги). На 6-ой неделе наблюдалось выпадение пера в области спины и шеи. Заболеваемость составляла 60 - 95\%, а смертность - 20 - 40\%, в отдельных партиях - 60\%. Описывая заболевание мускусных утят, J.F Bouquet (1981) отмечал потерю аппетита, быстрое снижение веса и их гибель.

W.Peter (1985) описал вспышки заболевания 1 - 2 - недельных гусят в округах Росток, Магдебург и Лейпциг (ГДР) с поражениями нервной системы, конъюнктивитами и диареей. Смертность нередко достигала 60 - 80\% гусят. В эксперименте болезнь характеризовалась параличами, выпадением пуха на спине и шее, диареей и отставанием в росте гусят.

Наряду с парвовирусной инфекцией многие исследователи отмечали течение рео- и аденовирусной инфекции у гусят с аналогичными клиническими признаками. Так, H.Krauss (1967) наблюдал у гусят при реовирусной инфекции слабость, угнетение, отказ от корма, затрудненное дыхание, потерю в массе, жидкий помет белого цвета, пух желтовато-коричневый.

W.Peter (1982) наблюдал у гусят младшего возраста депрессию, сонливость, снижение аппетита, истечения из носа и глаз, затрудненное дыхание, нарушение координации движений, выпадение пера в области спины и шеи, покраснение кожи.

Подобные клинические признаки обнаруживали у гусят при несба-лансированном кормлении (J.Mendelewska, F.Mendelewska, 1980; A.Vuillaume et al., 1982) и массовом заболевании неинфекционной этиологии (Т.М.Кравченко, В.В.Липская, 1966).

Как видно из материала, приведенного в данном разделе, в настоящее время обнаружено многообразие клинических признаков при вирусном энтерите гусей. Однако авторы не выделяют какой-нибудь патогномоничный признак. Кроме того, сходство симптомокомплекса парво-, адено- и реовирусной инфекций, а также болезней неинфекционной этиологии значительно затрудняет идентификацию вирусного энтерита в условиях птицефабрик.

Патоморфологические изменения при вирусном энтерите описаны многими исследователями.

По данным Л.М.Контримавичус (1968; 1972), М.В.Капитанаки, Л.Д.Чечула (1970), М.П. Кондакова (1973), В.С.Фадина с соавт., (1973), В.Ф.Макогона с соавт. (1974), Y.Samberg et al. (1972) наиболее характерные патологоанатомические изменения локализуются в желудочно-кишечном тракте. В железистом 
желудке отмечается катаральное воспаление слизистой оболочки с наличием большого количества густой слизи, а в мышечном - кутикулит.

У гусят 2 - 6-суточного возраста обнаруживали катаральное (Л.М.Контримавичус, 1968, 1972; Л.В.Капитанаки с соавт., 1970; L.Csontos, M.Csatari, 1967в, с) или геморрагическое (В.С.Фадин с соавт., 19736; А.Ф.Бондаренко, М.В.Капитанаки, 1975a, F.Szalai, S.Bernath, 1971; Y.Samberg et al., 1972) воспаление кишечника, а у старших (6 - 14 суток) - фибринозное воспаление (В.С.Фадин, 1972; В.Ф.Макогон с соавт., 1974). В просвете кишечника на всем его протяжении исследователи наблюдали серовато-белые плотные фибринозные тяжи, которые легко снимались при разрезе стенки кишки. По своей консистенции они рыхлые или плотные, имели слоистое строение с наличием внутри кормовых масс. Фибринозные «пробки» отдельные авторы (Л.М.Контримавичус с соавт., 1966; М.В.Капитанаки с соавт., 1970; В.И.Корнеева с соавт., 1973; Л.М.Контримавичус, 1974а; В.Ф.Макогон с соавт., 1974; А.Ф.Бондаренко, М.В Капитанаки, 19756) рассматривают в качестве диагностического признака вирусного энтерита, а по данным L.Csontos, M.Csatari (1967в), образование их является следствием осложнений, вызываемых сопутствующей микрофлорой.

В.С. Фадин (1972), Л.М. Контримавичус (1974а), В.Ф.Макогон с соавт., (1974), В.В.Малушко с соавт. (1980), Z.Nagy, D.Derzsy (1968), C.H.Schettler (1971), W.Peter (1985) на вскрытии обнаруживали воспаление и дегенеративные изменения в печени. Часто она была окрашена диффузно или очаговожелтый, иногда темно-коричневый цвет, увеличена, кровенаполнена, дряблой консистенции, редко с кровоизлияниями под капсулой. D.Derzsy (1967), Z.Nagy, D.Derzsy (1968) отмечали в печени геморрагии, некротические очаги, содержащие тельца Кунсильмана, а Е.А.Петелина (1984) при гистологическом исследовании отмечала вакуолизацию гепатоцитов.

Некоторые авторы (D.Derzsy et al., 1966; M.Coudert et al., 1972; Y.Samberg et al., 1972; H.C.Hansen, 1980) указывали на наличие кровоизлияний в легких, лимфоузлах или мышцах бедра, некрозов в поджелудочной железе и почках (C.H.Schettler, 1971в,c), отека мозга (Z.Nagy, D.Derzsy, 1968), деструктивных изменений на всех участках мозга, воспаления фабрициевой бурсы (F.Szalai, S.Bernath, 1971) и скопления серозного экссудата в брюшной полости (асцит) (Л.М.Контримавичус, 1978; M.Csatari, 1965; D.Derzsy, 1967; Y.Samberg et al., 1972; W.Peter, 1985).

Однако многие исследователи не находили энтерита у павших гусят, а выделяли как наиболее типичные при этом патологические изменения в печени и мускулатуре (A.A.S.Ahmed, 1973). Наиболее характерными при вирусном энтерите считали изменения в клетках мышечной ткани, включая скелетную мускулатуру, миокард, гладкую мышечную ткань кишечника. Изменения в 
скелетной мускулатуре развивались по типу ценкеровского некроза (Z.Nagy, D.Derzsy, 1968). Сердечная мышца характеризовалась дегенерацией, ее дряблостью и бледностью окраски, а в полости сердечной сорочки находили серозный или фибринозный экссудат, миокард утрачивал поперечную исчерченность (Л.М.Контримавичус 1968; 1972; 1974a; Z.Temesi, 1966; Y.Samberg et al., 1972; G.Dannacher et al., 1972; M.Coudert, 1973; W.Peter, 1985; V.Bergmann, 1987). M.Coudert et al. (1972, 1974) отмечали перикардит, гипертрофию сердца. Однако при этом А.В.Акулов, Л.М.Контримавичус (1975) не обнаруживали тяжелых поражений миокарда и другой мышечной ткани, как при естественном, так и при экспериментальном заражении гусят.

C.H.Schettler (1973) у экспериментально зараженных гусят установил коагуляционные некрозы по ходу капилляров печени и появление телец - включений в прилегающих к капиллярам гепатоцитах.

Von K.Ziedler et al. (1978) при патоморфологическом исследовании органов павших мускусных утят от вирусного энтерита установили изменения в печени, выражающиеся в дегенерации и некрозе клеток, в сердечной мышце - в бледной окраске, скоплении жидкости в полости, дегенеративных процессах и очаговом миелозе. У птиц старше 3-недельного возраста отмечали желеобразный налет на поверхности этих органов. В отдельных случаях обнаруживали некротические процессы в трубчатом эпителии и выраженный отек в легких. Незначительные реактивно-воспалительные явления наблюдали со стороны кишечника.

V.Bergmann (1987) наблюдал у павших гусят конъюнктивит, сморщивание селезенки и фабрициевой сумки, незначительный катаральный энтерит, гипертрофию печени. Гистологически автор демонстрировал и воспалительные изменения в сердечной мышце, лимфопластические процессы в селезенке, бурсе, тимусе, а у некоторых гусят - серозный гепатит и дегенерации клеток печени. Обнаруживал внутриядерные тельца - включения только в клетках миокарда и эпителия фабрициевой сумки.

По данным Е.А.Петелиной (1983; 1984) репликация вирулентного штамма вируса энтерита в энтероцитах тонкого отдела кишечника сопровождалась некрозом большинства клеток каемчатого эпителия, а репродукция его в гепатоцитах характеризовалась развитием диффузной жировой и вакуольной дистрофии в них. В то время аттенуированный штамм индуцировал слабые патологические изменения в энтероцитах с последующей регенерацией пораженных участков, а гепатоцитах - нуклеопатические процессы в единичных клетках.

Патоморфологические изменения при адено- и реовирусной инфекциях гусят во многом напоминали вирусный энтерит (H.Krauss, 1965, 1967; C.H.Schettler, 1971в; D.Derzsy et al., 1975; W.Peter, 1982). Однако V.Bergmann 
(1987) утверждал, что по сравнению с первичным патогенным действием парвовируса при болезни Держи изменения, вызываемые аденовирусами, как результат вторичной инфекции с незначительными повреждениями в органах. Исследованиями A.Vuillaume et al. (1982) установлено, что при нарушении условий выращивания и несбалансированном кормлении (основной компонент в рационе кукуруза и жмых) у гусят в возрасте 4 - 20 недель наблюдалась медленно развивающаяся болезнь, характеризующаяся миопатозом, нефритом, энтеритом и суставной подагрой.

Итак, клинические признаки, и патоморфологические изменения при парвовирусной инфекции не всегда бывают однотипными и ярко выраженными. Их проявление во многом зависит от характера течения болезни и осложнения ее различной микрофлорой, что затрудняет диагностику болезни (Л.М.Контримавичус, 1974а).

Многолетние исследования, проведенные в условиях гусеводческих хозяйств и эксперименте, по изучению клинического проявления и течения парвовирусной инфекции у гусят и мускусных утят показали, что клинические признаки у больных гусят были, в основном, однотипны в различных неблагополучных хозяйствах, но они различались в зависимости от возраста птиц (В.В.Малушко с соавт., 1980, 1983; В.В.Малушко, Б.Б.Трефилов, 1985, 1992; Б.Б.Трефилов, 1976, 1996 ). Так, на 4-6 сутки выращивания гусята в партии погибали внезапно без проявления каких-либо клинических признаков болезни, другие болели в течение 2-3 суток. Они становились малоподвижными, угнетенными, скучивались у источника тепла, отказывались от корма, но часто пили. 6 - 10 - суточные гусята садились на конечности, не могли передвигаться, вытягивали шею, находились в полусонном состоянии, глазная щель суживалась. При попытке подняться или передвигаться они клювом упирались в подстилку и погибали с нервными явлениями. Слабые, истощенные гусята неподвижно стояли, сгорбившись, шея их была вытянута, голова опущена, глаза полузакрыты, конечности полусогнуты, крылья отставлены. Иногда они запрокидывали голову назад, падали и не могли подняться. У многих больных гусят отмечали диарею, помет был жидким, водянистым или с примесью крови (рис. 6 на вкладке).

При ассоциированном течении болезни с аспергиллезом у больной птицы наблюдали затрудненное дыхание, с приоткрытым клювом.

При длительном течении болезни у гусят 15-20 - суточного возраста было плохое оперение, они выщипывали пух и перья, нанося кровоточащие раны в области спины, крыльев и хвоста (рис. 7а на вкладке). Гусята становились слабыми, развитие замедлялось, от 20-30\% птиц погибали в состоянии какехсии. Наблюдали отвисание живота и флюктуацию жидкости в грудобрюшинной полости. Больные гусята принимали позу пингвина (рис.7б на вкладке). 
Клинические признаки у гусят при смешанном течении вирусного энтерита с бактериальными инфекциями не отличались от тех, которые наблюдали при моноинфекции.

Патологоанатомическому исследованию было подвергнуто более 2000 павших гусят в возрасте 1-30 суток из неблагополучных по вирусному энтериту гусей хозяйств.

На вскрытии у гусят до 4-суточного возраста не отмечали характерных изменений, кроме катарального воспаления тонкого отдела кишечника, венозного застоя в печени и водянистого содержания кишечника. У многих павших гусят наблюдали большой не рассосавшийся жидкий желток, наличие уратов в мочеточнике.

У павших гусят в 6-12 - суточном возрасте дегенеративные изменения в паренхиматозных органах были более выражены.

В кишечнике чаще отмечали катарально-геморрагический или катаральнофибринозный энтерит. В просвете кишечника обнаруживали, преимущественно в тонком отделе, рыхлые фибринозные тяжи (рис.8 на вкладке). В железистом желудке находилось большое количество слизи, а слизистая оболочка была набухшая; у многих гусят - кутикула мышечного желудка отслаивалась.

Печень и почки были увеличены, полнокровны, дряблой консистенции, в печени отмечали некротические поражения под капсулой; желчный пузырь увеличен, напряжен. Изменения в почках характеризовались резко выраженными гемодинамическими нарушениями. Мускулатура сердца бледная, цвета вареного мяса, дряблая.

\section{5. Диагностика болезни}

В условиях гусеводческих хозяйств на основании эпизоотологических данных, клинической картины и патологоанатомических изменений ставят предварительный диагноз на парвовирусную инфекцию гусей.

Для подтверждения диагноза проводят изоляцию вируса на гусиных эмбрионах (Л.М.Контримавичус, 1974а, 1977, 1978; В.С.Фадин, 19756, 1977; Д.Держи с соавт., 1975; D.Derzsy et al., 1966, D.Derzsy, M.Szedo, 1973; C.H.Schettler, 1971a; J.Kisary et al., 1977; P.Have, H.C.Hansen, 1981). Адаптацию и выделение парвовируса проводят в культуре клеток гусиных эмбрионов (Л.М.Контримавичус, 1975; H.Krauss, 1965; С.H.Schettler, 19716, 1972; J.Kisary, D.Derzsy, 1974; J.Kisary et al., 1975a; J.Kisary, 1979), а идентификацию вируса - в реакции нейтрализации в культуре клеток (Л.М.Контримавичус, 19756, 1978, 1980; C.H.Schettler, 1972; P.Have, H.C. Hansen, 1981).

Кроме того, применяются иммунофлуоресцентный (К.П.Комиссаров, 1976; А.Ф.Бондаренко, 1982; C.H.Schettler, 1972; Ch.Labie, 1972; B.Dvorak, D.Dvorakowa, 1980) и иммуноферментный методы исследования (М.Фадель 
с соавт., 1989; Д.В.Маслов, 2006; А.В.Циновый, 2010; P.Have, Н.C.Hansen, 1981; J.Roszkowski et al., 1982; M.J.Kwang et al., 1987, 1988; Y.K.Liao, Y.S.Lu, 1990).

Для диагностики болезни В.С.Фадин (1973) предложил гистологический метод обнаружения телец - включений вирусного происхождения в ядрах нервных клеток продолговатого мозга и мозжечка.

Для серологической диагностики парвовирусной инфекции гусей применяют реакцию нейтрализации (Л.М.Контримавичус, Я.Кишари, 1976; Л.М.Контримавичус, А.В.Суворов, 1982, 1986; L.Csontos, M.Csatari, 1967в; D.Derzsy et al., 1970, 1973; A.A.S.Ahmed, 1973; J.Kisary et al., 1975в), реакцию диффузионной преципитации в геле (К.П.Комиссаров, 1976; В. М.Чекшиев, В.С.Фадин, 1976; А.Ф.Бондаренко, 1982; С.H.Schettler, 1976) и реакцию непрямой гемагглютинации (В.Г.Иващенко, 1986).

Некоторые исследователи отмечают, что при переболевании в сыворотке крови у гусят накапливаются вируснейтрализующие антитела, обусловливающие иммунитет (Л.М.Контримавичус, Я.Кишари, 1976; L.Csontos, M.Csatari, 1967в; C.H.Schettler, 1971в; D.Derzsy, 1973a; A.A.S.Ahmed, 1973).

W.Peter (1985), проводя серологические обследования поголовья гусей в округах Росток, Магдебург, Лейпциг, Эрфурт и Дрезден (ГДР), установил (по наличию вируснейтрализующих антител) широкое распространение вирусного энтерита.

По данным V.Marius et al. (1983) антитела к парвовирусу гусей были обнаружены в высоких титрах у мускусных утят-бройлеров при серологических исследованиях во Франции.

Л.М.Контримавичус (1978); C.H.Schettler (1971в); A.A.S.Ahmed (1973); D.Derzsy (1973a) отмечали, что гуморальные антитела от гусей родительского стада трансовариально передаются потомству, обеспечивая невосприимчивость гусят к полевому вирусу. A.A.S.Ahmed (1973) указывает, что степень и продолжительность материнского иммунитета зависят от количества приобретенных антител.

Л.М.Контримавичус, А.В.Суворов (1982) показали, что присутствие вируснейтрализующих антител к вирусу энтерита в сыворотке крови взрослых гусей и молодняка в титре 1:320 и выше служит показателем недавно имевшей место болезни, в то время как отсутствие антител свидетельствует о благополучии хозяйства.

По данным А.В.Суворова (1986) иммунный статус гусей хозяйств с различной эпизоотической ситуацией в отношении болезни характеризуется ростом вируснейтрализующих антител, достигающих $11,25 \log _{2}$ при острой вспышке и различным значением титра антител (от 2,66 до 9,3 $\log _{2}$ ) у гусей стационарно неблагополучных хозяйств.

При сравнительном изучении чувствительности реакции нейтрализации и РДП в геле для выявления уровня антител к парвовирусу гусей в сыворот- 
ке крови вакцинированных птиц и реконвалесцентов, а также в желтке яиц R.E.Gough $(1984,1987)$ показал, что реакция нейтрализации наиболее специфична, чем РДП в геле. Определение антител в желтках яиц дает возможность в лабораторных условиях ретроспективно устанавливать в стадах птиц контакт с парвовирусной инфекцией.

M.J.Kwang et al. (1987, 1988) разработали ELISA - метод для определения антител в сыворотке крови к парвовирусу гусей. Автор показал, что РДП в геле менее чувствительна по сравнению с ELISA - тестом.

V.Kardi, E.Szegletes (1996) разработали двойной сэндвич вариант ELISA для обнаружения антигена вируса болезни Держи в клеточных культурах. Этот метод дает возможность количественного определения вируса. Авторы также предложили блокирующий вариант ELISA для выявления титра специфических антител в сыворотке крови гусей.

Y.K.Liao, Y.S.Lu (1990) использовали метод ELISA и латекс- агглютинацию с целью обнаружения вирусного антигена при болезни Держи.

М.Фадель с соавт. (1989) разработали метод ИФА для обнаружения парвовируса гусей в патматериале от больных и эксперментально зараженных птиц. Показано, что метод специфичен и высокочувствителен и может быть использован для количественного определения антигена.

Б.Б.Трефилов с соавт. (2005, 2007); Д.В.Маслов (2006); Д.В.Маслов с соавт. (2006) разработали высокочувствительную иммуноферментную тестсистему для выявления специфических антител в сыворотке крови гусей. Набор предназначен для серологического контроля за распространением парвовирусной инфекции в популяциях гусей; оценки эффективности иммунизации поголовья против данной болезни и ретроспективной диагностики парвовирусной инфекции у гусей по приросту уровня специфических антител.

\section{6. Профилактика и меры борьбы}

В настоящее время профилактика и организация мероприятий по ликвидации вирусного энтерита гусей складывается из трех составных частей: проведение комплекса ветеринарно-санитарных мероприятий, обеспечивающих изолированное выращивание гусят от неблагополучного стада, использование химиотерапевтических препаратов и применение средств специфической профилактики (вакцин и сывороток).

По данным некоторых авторов (Л.М.Контримавичус с соавт, 1966; Л.М.Контримавичус, 1972, 1976; D.Derzsy et al., 1966; J.Zalay, 1967) антибиотики, нитрофурановые и сульфаниламидные препараты не оказывали лечебного эффекта при вирусном энтерите. Однако, учитывая их бактерицидное 
действие, рекомендовали применять эти препараты для воздействия на вторичную микрофлору.

М.В.Капитанаки с соавт. (1971, 1972); Л.Д.Чечула, М.В.Капитанаки (1971) получили положительные результаты при лечении больных гусят желудочным соком в комбинации с фуразолидоном. Препараты теброфен, оксолин, флореналь, ремантадин не оказывали ингибирующего действия на вирус энтерита в гусиных эмбрионах (И.В.Щеглова, В.В.Малушко, 1975).

Л.М.Контримавичус с соавт. (1966, 1968); Л.М.Контримавичус (1968); H.Krauss (1965); D.Derzsy et al. (1966); S.A.M.Cleef, van J.T.Miltenburg (1966); J.Zalay (1967); D.Derzsy (1969) установили превентивное действие сыворотки крови переболевших гусят и предложили ее для профилактики заболевания.

Многие исследователи (В.С.Фадин, Л.Дедкова, 1970; В.С.Фадин с соавт., 1971; Л.Д.Чечула, М.В.Капитанаки, 1971; В.С.Фадин, 19736, 1975а, 19796, 1980; А.Ф.Бондаренко, М.В.Капитанаки, 1975а; В.Г.Руднякова, 1976; Л.М.Контримавичус, 1978; В.Ф.Макогон, 1979; В.В.Малушко о соавт., 1980, 1983; А.Шлапаченко с соавт., 1981; А.Ф.Бондаренко, 1982; Б.Б.Трефилов, 1996; T.Suveges, I.Szecsenyi, 1970; D.Derzsy, 19736; M.Szedo, 1971; C.H.Schettler, 1971; Y.Samberg et al., 1972; J.Hoekstra et al., 1973) считали серопрофилактику как основной метод борьбы с парвовирусной инфекцией гусей в неблагополучных хозяйствах, учитывая протективное свойство сыворотки.

Наряду с данными о снижении потерь при применении сыворотки крови реконвалесцентов, имеются сообщения об их не эффективности (В.Ф.Макогон, 1979; S.Bernath, F.Szalai, 1970; C.H.Schettler, 1977). Одной из причин снижения лечебно-профилактической эффективности сыворотки является снижение титра антител в крови переболевших гусят с увеличением их возраста (D.Derzsy et al., 1966). Так, сыворотка, полученная от гусят - реконвалесцентов в 4-5-недельном возрасте предохраняла гусят от заболевания, а в 3-месячном возрасте протективными свойствами не обладала при введении ее гусятам даже в больших дозах $\left(2-3 \mathrm{~cm}^{3}\right)$.

В.В.Малушко о соавт. (1980) отмечали, что сыворотка или кровь гусят- реконвалесцентов старше 2,5 месяцев не защищала птицу от естественного заражения. Кроме того, различие в антигенном отношении штаммов возбудителя позволяет применять сыворотку лишь в тех хозяйствах, откуда она была получена (В.В.Малушко с соавт., 1976).

Дозы, кратность и сроки введения сыворотки до настоящего времени достаточно не изучены. Поэтому одни авторы ее применяют однократно (Л.М.Контримавичус с соавт., 1966; S.A.M.Cleef, van J.T.Miltenburg, 1966), другие - двукратно (Л.М.Контримавичус с соавт., 1966; J.Zalay, 1967) и трехкратно подкожно в дозах от 0,5 до 3,0 см3 с интервалом от 1 до 5 суток (M.Coudert et al., 1973). Вероятно, вследствие этого эффективность препарата варьирует 
(Л.М.Контримавичус с соавт., 1966; В.С.Фадин с соавт., 1971; Н.Krauss, 1965; T.Suveges, I.Szencsenyi, 1970; M.Szedo, 1971; J.Hoekstra, H.Yadin, 1973).

Данные J.Kisary, J.Meszaros, (1977) свидетельствуют о том, что специфическая антисыворотка, введенная гусятам одновременно или не позже одних суток после экспериментального заражения, защищала их от заболевания. В то время как при обработке позже 34 часов сыворотка не давала эффекта.

Во Франции (M.Coudert et al., 1973) рекомендовали вводить сыворотку реконвалесцентов в дозе 2 см $^{3}$ гусятам в возрасте 2, 15, и 30 суток. В СССР исследователи применяли сыворотку реконвалесцентов двукратно, в одно- и четырехсуточном возрасте в дозах 0,5 и 1,0 см³ соответственно (Л.М.Контримавичус с соавт., 1966; Л.М.Контримавичус, 1978, 1969, 1972, 19756; В.Ф.Макогон с соавт., 1974; В.Ф.Макогон, 1979), так как однократные введения малых доз сыворотки иногда бывают недостаточными для защиты гусят от заболевания (Л.М.Контримавичус, 1978).

Другие авторы (В.С.Фадин с соавт., 1971, 1976; М.В.Капитанаки с соавт., 1971, 1972; Л.Д.Чечула, М.В.Капитанаки, 1971; В.С Фадин, Н.М.Мельников, 1973; В.С.Фадин, 19756, М.Coudert et al., 1972) использовали цитратную кровь гусят-реконвалесцентов для профилактики парвовирусной инфекции гусей. По сообщению М.В.Капитанаки с соавт. (1972) применение крови от гусынь родителей не давало положительного эффекта.

D.Derzsy, (1969, 1970), S.Bernath, F.Szalai, (1970) установили протективные свойства гипериммунной сыворотки, полученной на гусях. Авторы инокулировали двукратно в дозах 1,0 и 2,0 см³ гусятам в возрасте 1 и 5 - 7 суток соответственно. C.H.Schettler (1971a) показал ингибирующее действие гипериммунной сыворотки на парвовирус в опытах на 7- 8-суточных гусиных эмбрионах.

По данным А.П.Кондакова, В.С.Фадина (1977) морфологическая реакция в органах у гусят отмечена на введение крови от реконвалесцентов, характеризующаяся воспалителъно-деструктивными процессами в кишечнике, а позднее - пролиферативно-гиперпластическими в фабрициевой сумке и селезенке.

В.В.Малушко с соавт. (1980, 1984); И.В.Щеглова с соавт. (1980), А.Ф.Бондаренко (1982) сообщили о применении гипериммунных сывороток, полученных на млекопитающих животных, для борьбы с вирусным энтеритом гусей.

В ряде стран созданы живые (J.Hoekstra et al., 1973; J.Kisary et al., 1975в; J.Kisary, J.Meszaros, 1977; H.C.Hansen, 1979; R.E.Gough, D.Sparckman, 1982) и инактивированные вакцины против парвовирусной инфекции гусей (B.Dvorak, D.Dvorakowa, 1980; J.Snoflak, H.Vachova, 1982). Так, в Чехословакии получена вакцина из суспензии гомогената 10-суточных гусиных эмбрионов, зараженных парвовирусом штамма «V34/74 SVU», инактивированная бетапропиолактоном, 
адсорбированная гидроксалом и консервированная формалином (J.Snoflak, H.Vachova, 1982).

При конструировании вирусвакцины патогенные штаммы аттенуировали серийными пассажами в культурах клеток гусиных (J.Kisary et al., 1975в, 1977) или утиных (J.F.Bouquet, 1981) эмбрионов, а также пассированием в развивающихся утиных эмбрионах (R.E.Gough, D.Sparckman, 1982). Об иммуногенных свойствах вакцинных штаммов авторы судили по результатам биопробы на 1-3-суточных гусятах (J.Kisary, J.Meszaros, 1977; R.E.Gough, D.Sparckman, 1982) и по уровню гуморальных антител (J.Hoekstra et al., 1973; J.F. Bouquet, 1981). Так, J.Kisary et al. (1977) отмечают, что вирусвакцина из штамма "BAV» индуцирует образование вируснейтрализующих антител класса IgM и IgG. Эти авторы, а также R.E.Gough, D.Spackman (1982); J.Snoflak, H.Vachova (1982) установили нарастание титра вируснейтралиэующих антител у иммунизированных гусей, а продолжительность поствакцинального иммунитета была различной.

Установлено, что иммунитет у гусей родительского стада передается потомству трансовариально (J.Kisary, J.Meszaros, 1977; J.Snoflak, D.Sparckman, 1982). Антитела желточного происхождения обнаруживаются в сыворотке крови гусят в течение 3 недель, что достаточно для их защиты от болезни в восприимчивый период (J.Kisary, J.Meszaros, 1977), титр которых составлял 4,0 - 5,0 $\log _{2}$ (И.В.Щеглова, В.Г.Иващенко, 1985).

J.Kisary, J.Meszaros (1977a, b); J.Kisary et al. (1978); J.Kisary (1986) предложили вакцинировать гусынь перед яйцекладкой и один раз в период ее пика, а гусят на 3 неделе, между 15-20 днями их жизни. По мнению V.Marius et al. (1983), вакцинировать птицу старше 21 - 28-суточного возраста нецелесообразно, так как она в это время уже не восприимчива к парвовирусу. Авторы вводили вакцину внутримышечно в грудную мышцу или подкожно

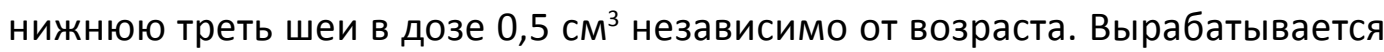
напряженный иммунитет, который необходим для защиты потомства от заражения в течение 3 - 4 недель.

Для специфической профилактики вирусного энтерита гусей в Российской Федерации предложены вирусвакцины ВНИВИП и ВИЭВ соответственно из аттенуированного “клона 6» и штамма «Лив» (Б.Б.Трефилов, 1990, 1995, 1998, 2000, 2004, 2007, 2008; В.В.Малушко, Б.Б.Трефилов, 1992).

Анализ литературных данных свидетельствует о том, что для вакцинопрофилактики вирусного энтерита (парвовирусной инфекции) гусей применяют на практике как аттенуированные, так и инактивированные вакцины (П.С.Юрко с соавт., 2010). 


\section{ГЛАВА 4. \\ Разработка средств специфической профилактики парвовирусной инфекции гусей}

\section{1. Селекция вакцинного клона парвовируса гусей}

В процессе производства вирусвакцины важное место занимает получение апатогенного высокоиммуногенного штамма парвовируса. Используя метод негативных колоний (бляшек), в культуре клеток гусиных эмбрионов Б.Б. Трефиловым (1989) выделен «клон 6» штамма «П-75». Клон вируса изучен по морфологии бляшек, способности к репликации в культуре клеток гусиных эмбрионов, патогенности (P - признаку) для гусиных эмбрионов и гусят, антигенности , иммуногенности (Б.Б.Трефилов, 2000). Изучение генетической однородности «клона 6» показало, что он индуцирует образование под агаром однотипных по морфологии мелких (1-2 мм в диаметре) бляшек в титрах 4•10-4 - 1,5•10-5 БОЕ/см³. При экспериментальных пассажах «клон 6» $\mathrm{S}_{-\mathrm{Tc}}$ и $\mathrm{PI}^{\mathrm{C}}$ признаки не изменяются. Максимальное накопление вируса в культуре гусиных фибробластов

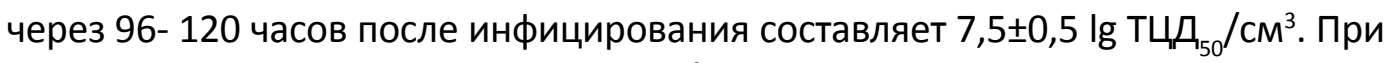
культивировании при температуре $34{ }^{\circ} \mathrm{C}$ «лон 6» проявляет цитопатическую

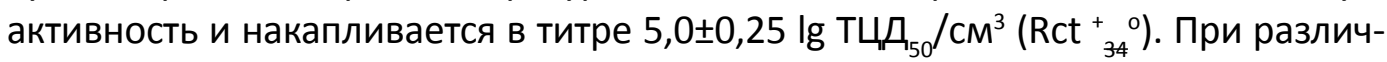
ных методах заражения «клон 6» не вызывает гибель и патологоанатомические изменения у 10 - 12 - суточных гусиных эмбрионов и 1-2 - суточных гусят (Pgle- , Pgl-) и сохраняет степень аттенуации после 10 - кратных пассажей на гусиных эмбрионах и чувствительных гусятах. При внутримышечном введении в дозе 3,0 lg ТЦД $/ \mathrm{cm}^{3} 2$ - суточным гусятам и взрослым гусям «клон 6» индуцирует синтез вируснейтрализующих антител в сыворотке крови через 14 сут. соответственно в титрах 6,32 и 7,3 $\log _{2}$, а на 21 сут. титр антител у гусят и взрослых гусей составляет 8,5 $\log _{2}$. При контрольном заражении эпизоотическим штаммом парвовируса в дозе 3,0 lg LD 50 иммунизированные гусята устойчивы в 88,5 \pm $2,5 \%$ случаев $(r=-0,5, \mathrm{P}<0,01)$.

В ГНУ ВНИВИП Россельхозакадемии селекционирован «Штамм Goosa parvovirus для приготовления вакцинных препаратов против вирусного энтерита гусей» (Патент РФ на изобретение № 1499917 от 1993г.), (В.В.Малушко с соавт., 1993).

\section{2. Отработка оптимального режима культивирования вируса}

Эффективность технологии получения высококачественного вирусного сырья зависит от клеточной модели, штамма вируса, способа выращивания клеток и вируса, условий их культивирования и ряда других факторов, приоб- 
ретающих особое значение при производстве вирусвакцины. Так, ранее для получения вирусного сырья применялся широко распространенный способ пристеночного выращивания клеток в матрасах. Однако этот метод ввиду малой производительности и большой трудоемкости малопригоден для промышленного использования. В настоящее время наиболее универсальным признан роллерный способ получения клеток.

Основной задачей при отработке режима культивирования культуры гусиных фибробластов в круговом монослое является нахождение оптимальных условий для размножения клеток в 5 - литровых узкогорлых бутылях на роллерной установке при температуре $37^{\circ} \mathrm{C}$ со скоростью вращения сосудов 10 об/ час. Установлено, что конечная концентрация клеток в 1,0 см³ среды при объеме

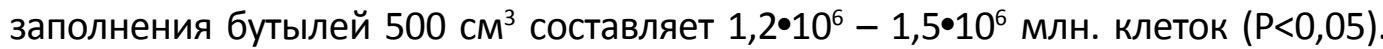
Изучение эффективности репликации «клона 6» парвовируса гусей в роллерной установке и стационарных условиях показало, что оптимальными критериями культивирования культуры гусиных фибробластов являются: гусиные эмбрионы 14-16 - суточной инкубации; посевная концентрация 0,65•106 - 0,75•106 клеток/

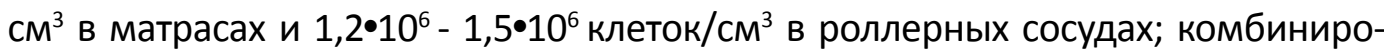
ванная среда роста, состоящая из среды Игла МЕМ - 60\%, среды 199 - 30\%, нормальная сыворотка крупного рогатого скота - 10\%, антибиотики (натриевая соль бензилпенициллина 100 ЕД/см³ и сульфата стрептомицина 100 мкг/см3); температура культивирования $(37,5 \pm 0,5)^{\circ} \mathrm{C}$. Таким образом, биологическая активность «клона 6» парвовируса гусей при культивировании в стационарных условиях достигает 6,0-6,5 Ig ТЦД $/ \mathrm{cm}^{3}$, а при культивировании в роллерной установке - 7,5-8,0 lg ТЦД $/$ см³ $^{3}$. Следовательно, метод культивирования вакцинного производственного «клона 6» парвовируса в роллерной установке характеризуется большей эффективностью по сравнению со стационарным методом. Постоянная аэрация в сочетании с непрерывным перемешиванием питательной среды создают наиболее благоприятные условия для роста клеток и адсорбции вируса, что способствует накоплению вирусного сырья в высоких титрах для изготовления высокоиммуногенной вирусвакцины (Б.Б.Трефилов, 2000).

\section{3. Сроки наступления и продолжительность иммунитета}

Определение ИмД от 500 ТЦД $_{50}$ до 10 млн. ТЦД вакцинированных и контрольных гусят штаммом «П-75» в дозе 3,0 lg LD ежедневно со 2-х - по 7-е сутки и через 15 суток после иммунизации показало, что ИмД

При изучении биосинтеза белка в иммунокомпетентных органах у вакцинированных гусят с помощью ${ }^{14}$ С-глицина установлено, что на 3-е сутки про- 
исходит активация синтеза белка в тимусе и бурсе Фабрициуса на 12 и 9\% соответственно. Уровень $\gamma$ - глобулинов в сыворотке крови не изменялся. На 7-е сутки синтез белка повышается в тимусе на 17\%, в бурсе на $15 \%$ и в селезенке на $29 \%$, а уровень $ү$ - глобулинов в сыворотке крови увеличивается на $38 \%$. Полученные данные коррелируют с повышением уровня вируснейтрализующих антител в сыворотке крови и устойчивостью вакцинированных гусят к эпизоотическому вирусу (Б.Б.Трефилов, 1995, 2000).

Влияние иммуностимуляторов на формирование поствакцинального иммунитета изучено на 2 - суточных гусятах (Б.Б.Трефилов, 1995, 2000). Автор показал, что титр вируснейтрализующих антител (ВНА) у иммунизированных гусят вакциной из “клона 6» без добавления иммуностимуляторов составляет 4,0 $\log _{2}$, а при сочетанном применении вакцины с иммуностимулятором титр специфических антител в среднем повышается на 1,5 - 3,0 $\log _{2}$. Бактерицидная и лизоцимная активности сыворотки крови по сравнению с контролем при введении вакцины с иммуностимулятором повышается на 30 и $80 \%$ соответственно.

Б.Б.Трефилов $(1993,2000)$ при вакцинации гусей родительского стада в производственных условиях внутримышечно двукратно с интервалом 20-25 суток за 1,0-1,5 месяца до начала яйцекладки в дозах 5,0 , 6,0 и 6,5 lg ТЦД отмечал выраженную сероконверсию. После первой вакцинации в дозе 5,0 и 6,0 lg ТЦД $\log _{2}$, а после ревакцинации в дозах 6,0 и 6,5 Ig ТЦД крови - 7,8 и 8,7 $\log _{2}$. В желтке яиц от вакцинированных гусынь титры ВНА составляют 6,0 и 6,68 $\log _{2}$, а в сыворотке крови суточных гусят - 7,0 и 8,0 $\log _{2}$ $(P<0,05)$. Выводимость гусят повышается на 5-6\%, а выход здорового молодняка - на 3-5\%.

При контрольном заражении 2- суточных гусят эпизоотическим штам-

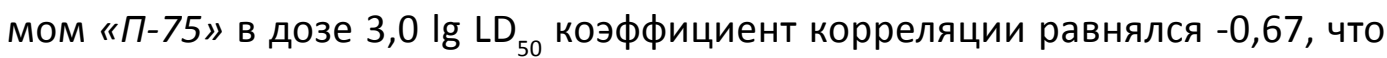
указывает на умеренную защиту гусят и свидетельствует о том, что вакцина вызывает иммунологическую перестройку в организме гусынь. Материнские антитела передаются потомству и обеспечивают устойчивость гусят к полевому заражению впервые 2-3 недели жизни.

Результаты изучения продолжительности поствакцинального иммунитета по серологическим показателям и устойчивости гусят к контрольному заражению показали, что в сыворотке крови вакцинированных гусынь через 50 суток, 5 и 7 месяцев титры ВНА равняются 8,2, 8,0 и 6,0 $\log _{2}$ соответственно, что свидетельствует о снижении титра антител. Устойчивость гусят составляет 88,5 \% при $r=-0,66,(P<0,05)$. 


\section{4. Разработка технологии изготовления и методов контроля вирусвакцины ВНИВИП сухой культуральной против вирусного энтерита гусей}

Основным этапом технологического процесса изготовления биопрепаратов является культивирование клеточных культур и микроорганизмов. Известно, что при достаточной степени оптимизации культивирования и подбора тест-системы можно получить максимальное накопление антигена с единицы субстрата, обладающего высокими антигенными и иммуногенными свойствами.

В лабораторных и биофабричных условиях установлено, что оптимальной тест-системой является культура клеток гусиных эмбрионов при роллерном способе культивирования вируса. При этом максимальное накопление «клона 6» парвовируса в титре 7,5 \pm 0,5 lg ТЦД $/{ }_{50} / \mathrm{cm}^{3}$ происходит через 72-96 часов культивирования. Оптимальные параметры приготовления и культивирования культуры клеток изложены в предыдущих главах.

В процессе изготовления вакцины для ее стабилизации используют следующие защитные среды: СПЛФ и ВНИВИП на основе пептона и обезжиренное молоко.

Контроль вакцины осуществляют в соответствии с СТО 00495674-00082008 по физическим свойствам и биологической активности через 6 и

12 месяцев хранения при температуре $4^{\circ} \mathrm{C}$. Показано, что физические свойства соответствуют параметрам, которые приведены в СТО. Биологическая активность контролируемых серий вакцины со средами высушивания СПЛФ и ВНИВИП в процессе хранения практически не меняется 6,25 - 6,5 и 6,25 lg ТЦД ${ }_{50} / \mathrm{cm}^{3}$ (6 месяцев); 6,2 - 6,3 и 6,20 lg ТЦД $/ \mathrm{cm}^{3}$ (12 месяцев), а с обезжиренным молоком - 6,0 Ig ТЦД $/ \mathrm{cm}^{3}$. Полученные данные свидетельствуют о целесообразности замены обезжиренного молока на среду ВНИВИП ввиду простой методики приготовления по сравнению с СПЛФ, и обеспечения максимальной сохранности вируса. На основании полученных результатов разработана нормативная документация на промышленное производство вирусвакцины ВНИВИП сухой культуральной против вирусного энтерита гусей (В.В.Малушко с соавт., 1990; Б.Б.Трефилов, 1990; Б.Б.Трефилов с соавт., 2008).

\section{5. Разработка инактивированной вакцины против парвовирусной инфекции гусей}

В настоящее время большинство исследователей (Е.В.Ельников, 2003; В.В.Борисов с соавт., 2003; Э.Д.Джавадов, 2004; О.В.Бородина, 2005; П.С.Юрко с соавт., 2005; И.А.Борисова, 2008; Э.Д.Джавадов с соавт., 2009; Б.Б.Трефилов с 
соавт., 2009, 2012, 2013; А.О.Михайлов, 2010) склонны отдавать предпочтение инактивированным вакцинам, так как они создают длительный напряженный иммунитет, разрешают проблему нежелательных поствакцинальных реакций, исключают возможность заражения восприимчивой птицы и возникновение латентной инфекции, обусловленной вакцинным вирусом.

При разработке технологии изготовления инактивированной вакцины против парвовирусной инфекции Б.Б.Трефилов с соавт. $(2009,2012)$ считают, что основное внимание следует обращать на следующие этапы:

подбор производственного штамма парвовируса;

оптимальные условия культивирования вируса;

выбор инактиванта и отработка методики инактивации вируса;

разработка компонентного состава инактивированной вакцины;

контроль физических и иммунобиологических свойств вакцины;

испытание антигенных и иммуногенных свойств вакцины.

Для получения вирусного биосырья, которое занимает важное место в технологии изготовления инактивированной вакцины против парвовирусной инфекции гусей, авторы в качестве штамма вируса использовали депонированный во ВГНКИ №71 производственный «клон 6» штамма «П75» парвовируса и патентированный, как «Штамм Goosa parvovirus для приготовления вакцинных препаратов против вирусного энтерита гусей» (патент №1499917, 1993).

Отработка режима культивирования культуры гусиных фибробластов роллерным способом и оценка степени репродукции вакцинного парвовируса гусей описаны в разделе «Разработка средств специфической профилактики парвовирусной инфекции гусей».

Ключевым этапом в изготовлении инактивированных вакцин является выбор инактиватора вируса. Главными критериями эффективности его действия являются полнота и необратимость вирулентных свойств вируса с максимальным сохранением целостности антигенных структур вирионов, обеспечивающих специфический иммунный ответ у привитого организма.

Для инактивации парвовируса гусей используются формальдегид и производные азиридинового ряда (аминоэтилэтиленимин) (А.О.Михайлов, 2009; 2010; Б.Б.Трефилов с соавт., 2009). Формальдегид при инактивации вызывает денатурирующие действие на поверхностные белки вириона, что может искажать рецепторы вирусного капсида и тем самым снижать его антигенную специфичность. Результаты инактивации вируса аминоэтилэтиленимином (АЭЭИ) представлены в табл. 4. 
Таблица 4

Данные кинетики инактивации парвовируса гусей аминоэтилэтиленимином

\begin{tabular}{|c|c|c|c|c|}
\hline \multirow{2}{*}{$\begin{array}{c}\text { Концентрация } \\
\text { АЭЭИ, \% }\end{array}$} & \multicolumn{4}{|c|}{ Значения инактивации, Ig } \\
\cline { 2 - 5 } & $\mathbf{6}$ & $\mathbf{1 2}$ & $\mathbf{1 8}$ & $\mathbf{2 4}$ \\
\hline 0,02 & 0,90 & 0,80 & 0,62 & 0,36 \\
\hline 0,05 & 0,74 & 0,69 & 0,46 & 0,10 \\
\hline 0,10 & 0,55 & 0,50 & 0,39 & 0,00 \\
\hline 0,20 & 0,46 & 0,33 & 0,23 & 0,00 \\
\hline
\end{tabular}

Данные, приведенные в таблице 4, свидетельствуют о том, что скорость икативации парвовируса аминоэтилэтиленимином находится в прямой зависимости от концентрации препарата и времени воздействия. Кинетика инактивации парвовируса гусей, обработанного различными концентрациями $(0,05$; 0,02; 0,1; 0,2\%) АЭЭИ при температуре $37^{\circ} \mathrm{C}$ и $\mathrm{pH} 7,2$ в режиме постоянного перемешивания, показала, что скорость инактивации ускоряется по мере увеличения концентрации препарата в вируссодержащей суспензии. При обработке вируса инактивантом в концентрации 0,1\% при температуре $37^{\circ} \mathrm{C}$ и экспозиции 24 часа константа инактивации подтверждает полную потерю инфекционной активности вируса с сохранением его антигенных свойств, что подтверждено на серонегативных гусятах 120-суточного возраста.

В ветеринарной практике птицеводческой отрасли применяют две формы инактивированных вакцин: сорбированную и эмульгированную. Важным этапом по конструированию оптимальной формы инактивированной вакцины против парвовирусной инфекции гусей является подбор эффективных адъювантов. Для изготовления эмульгированной формы вакцины применяется масляный адъювант Montanide ISA 70 производства фирмы «SEPPIC», образующий эмульсию обратного типа. При конструировании эмульгированной формы соотношение вирусного сырья в водной фазе и масляного адъюванта Montanide ISA 70 составляет 30:70, рекомендованном производителем, а вирусный антиген используют с активностью до инактивации 7,5-8,0 lg ТЦД/ $\mathrm{cm}^{3}$.

Одним из звеньев контроля качества инактивированных вакцин в процессе производства и хранения является определение физических свойств (стабильность эмульсии, гранулометрический состав, кинематическая вязкость). Установлено, что физические свойства инактивированной эмульгированной вакцины в процессе хранения существенно не изменяются и остаются в пределах нормативных требований. Высокая стабильность вакцинной эмульсии, низкая вязкость и высокая гомогенность дисперсной фазы в вакцине сохраняются как до, так и после хранения в течение 12 месяцев при температуре от +2 до $+8^{\circ} \mathrm{C}$ (табл. 5) (Б.Б.Трефилов с соавт., 2010; А.О.Михайлов, 2010). 
Таблица 5

Физические свойства инактивированной эмульгированной вакцины против ПВИ гусей после изготовления и в течение 12 месяцев хранения

\begin{tabular}{|c|c|c|c|c|}
\hline \multirow{2}{*}{$\begin{array}{c}\text { Срок } \\
\text { хранения }\end{array}$} & $\begin{array}{c}\mid 4 \\
\text { Вязкость, } \\
\text { мм²/c }^{2}\end{array}$ & $\begin{array}{c}\text { Центрифуги- } \\
\text { рование }\end{array}$ & $\begin{array}{c}\text { Экспресс- } \\
\text { метод }\end{array}$ & $\begin{array}{c}\text { Быстрое } \\
\text { старение }\end{array}$ \\
\hline До хранения & 48 & 100 & 100 & 100 \\
\hline 12 мес. & 55,0 & 98,5 & 98,5 & 98,5 \\
\hline
\end{tabular}

Антигенные и иммуногенные свойства инактивированной вакцины оценивают по изменению серологических показателей у вакцинированных гусей, а так же уровня антител в желтке яиц и суточных гусят, полученных от привитых гусынь. Результаты исследований свидетельствуют о том, что у иммунизированных гусей наступает выраженная сероконверсия. Повышение титра антител наблюдается постепенно, и максимальных значений титр достигает к 30-90 суткам после введения вакцины. Величины титров антител, полученные как в реакции нейтрализации в культуре клеток гусиных эмбрионов, так и методом иммуноферментного анализа показывают выраженную корреляцию $(r=-0,9)$. При изучении влияния различных доз антигена в вакцине на иммуногенные показатели установлена прямая зави-

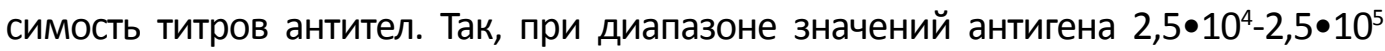
ТЦД/0,5 см³ титры антител равнялись в ИФА на 28 и 42 сутки

(1:7011 \pm 167$)-(1: 11299 \pm 192)$ и (1:8671 141$)-(1: 10220 \pm 161)$ соответственно (значение титров в обратных величинах). Продолжительность антигенного ответа на инактивированную эмульгированную вакцину изучена в течение 17 месяцев. Результаты исследований сывороток крови в ИФА представлены в таблице 5 и на рисунке 9 на вкладке.

Таблица 5 Титр специфических антител у вакцинированных против парвовирусной инфекции гусей инактивированной эмульгированной вакциной

\begin{tabular}{|c|c|c|c|c|c|c|c|c|c|c|c|}
\hline \multirow{2}{*}{$\begin{array}{l}\text { Наимено- } \\
\text { вание } \\
\text { групп }\end{array}$} & \multicolumn{11}{|c|}{$\begin{array}{c}\text { Титры антител в ИФА, значения обратные } \\
\text { Сроки после вакцинации, сут }\end{array}$} \\
\hline & 30 & 60 & 90 & 120 & 150 & 180 & 210 & 270 & 360 & 450 & 510 \\
\hline 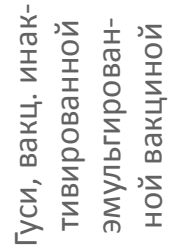 & 12710 & 13028 & 14016 & 11799 & 11105 & 8539 & 8519 & 4184 & 4222 & 4320 & 1750 \\
\hline
\end{tabular}


Данные, приведенные в таблице 4 и на рис. 9 на вкладке, показывают, что уровень антител в сыворотке крови вакцинированных гусей инактивированной вакциной были максимальными в течение 5 месяцев, а через 6 месяцев они уменьшаются на 23\%, а в течение последующих 6-ти месяцев титры сохраняются на одном уровне, в среднем 1:4200. Через 17 месяцев после вакцинации уровень антител составляет 1:1750, что обеспечивает защиту гусят от заражения (Б.Б.Трефилов с соавт., 2010).

Установлено, что в желтке яиц уровень материнских антител в реакции нейтрализации колеблется в пределах от 9,0 до 7,0 $\log _{2}$ в зависимости от сроков после вакцинации, а титр антител в ИФА у 2-3 - суточных гусят равняется 1:6573. При контрольном заражении показана 100\%-ная иммуногенная эффективность с коэффициентом корреляции $r=-1,0$ (А.О.Михайлов, 2010).

Таким образом, разработанная инактивированная эмульгированная вакцина против парвовирусной инфекции вызывает иммунобиологическую перестройку в организме гусей, индуцируя выработку специфических антител в высоких титрах, которые обеспечивают защиту молодняка гусей в восприимчивый период от болезни. На вакцину получен патент на изобретение «Вакцина и способ вакцинации против парвовирусной инфекции гусей» (патент РФ №2420571, 2010), (Б.Б.Трефилов с соавт., 2010).

\section{6. Стратегия профилактики болезни}

Предупреждение парвовирусной инфекции гусей достигается выполнением следующих хозяйственных и ветеринарно-санитарных мероприятий в гусеводческих и фермерских хозяйствах:

соблюдение оптимальных условий содержания и сбалансированного кормления;

предупреждение заноса инфекции в благополучное хозяйство и стадо;

применение эффективных схем специфической профилактики молодняка и родительского стада;

Возможные схемы вакцинации с использованием аттенуированной вирусвакцины и инактивированного препарата в хозяйствах с различной эпизоотической ситуацией:

\section{а) хозяйства (стада) благополучные по парвовирусной инфекции:}

схема 1 - инактивированный вакцинный препарат на родителях за месяц до начала репродуктивного периода согласно Инструкции по применению; схема 2 - аттенуированная вирусвакцина согласно Инструкции по применению. 


\section{б) хозяйства (стада) стационарно неблагополучные по парвовирусной инфекции:}

схема - инактивированный вакцинный препарат на родителях за месяц до начала яйцекладки согласно Инструкции по применению.

в) хозяйства (стада) с острой вспышкой парвовирусной инфекции:

схема 1 - аттенуированная вирусвакцина на гусятах суточного возраста согласно Инструкции по применению, ревакцинация ремонтного молодняка через 2 мес. инактивированным вакцинным препаратом согласно Инструкции по применению.

схема 2 - специфическая гипериммунная сыворотка или кровь гусятреконвалесцентов в суточном возрасте одновременно (симультанно) с инактивированным вакцинным препаратом для ремонтного молодняка.

Успех специфической профилактики парвовирусной инфекции зависит от правильной организации и качественного проведения зооветеринарных мероприятий и контроля над ними (Б.Б.Трефилов с соавт., 2012, 2013). 
Увеличение выхода молодняка гусей, обеспечение его благополучного роста и развития это не только насущная необходимость для мобилизации резервов производства, но и решающий фактор эффективного ведения птицеводства, позволяющий удовлетворить потребность населения в продуктах питания, а промышленность - в сырье.

Анализ структуры заболеваемости по регионам и в целом по стране показывает, что в последние годы на фоне относительно стабильного благополучия по парвовирусной инфекции постоянно имеют место возникающие спорадические случаи болезни.

Существенными факторами, способствующими появлению случаев заболевания, следует считать создание благоприятных условий для пассирования условнопатогенных микроорганизмов: высокая плотность посадки поголовья, неоднородность его иммунологического статуса, оптимальные условия среды обитания для возбудителей, а также несвоевременное проведение противоэпизоотических мероприятий без учета биологии возбудителя, как его способности длительного бессимптомного персистирования в организме взрослого поголовья гусей.

В случае возникновения смешанных инфекций болезнь принимает массовый характер, взаимодействие возбудителей чаще всего характеризуется синергизмом.

Учитывая эти обстоятельства и принимая во внимание поток информации по парвовирусной инфекции в течение последних двух-трех десятилетий, убедили нас в актуальности и своевременности ее обобщения и издания монографии с включением результатов собственных экспериментальных и производственных исследований.

Результатами обширных исследований в 1973 - 2013 гг. сотрудниками отдела вирусологии и опухолевых болезней птиц ГНУ ВНИВИП Россельхозакадемии в области патологии гусей в более 60 гусеводческих хозяйствах установлено, что болезнь вызывается парвовирусом из семейства Parvoviridae.

На основании эпизоотологических наблюдений, клинико-патологических данных и результатов лабораторных исследований выявлено широкое распространение в птицехозяйствах парвовирусной инфекции гусей. Установлена антигенная идентичность эпизоотических и эталонных штаммов вируса, но отличающихся по вирулентности и степени нейтрализации. Доказана необходимость разработки средств и методов экспресс-диагностики и специфической профилактики против данной инфекции. Поэтому проведено клонирование эпизоотических штаммов парвовируса и сравнительное изучение генетических признаков клонов. Для производства вакцинных препаратов се- 
лекционирован аттенуированный, ареверсибельный и высокоиммуногенный «клон 6» штамма «П-75» парвовируса гусей и депонирован во ВГНКИ ветпрепаратов и получен патент на изобретение РФ (патент № 1499917, 1993).

Сотрудниками отдела разработана технология биофабричного изготовления и методы контроля вирусвакцины сухой культуральной ВНИВИП против вирусного энтерита гусей (патент РФ № 2118539, 1998). Экспериментальные и производственные испытания опытных и биофабричных серий вирусвакцины ВНИВИП показали ее безвредность, стабильность и высокую антигенную и иммуногенную активность, как на гусятах, так и на взрослых гусях. По результатам испытаний разработана нормативная документация на вакцину (СТО 00495674-0008-2008 и Инструкция по применению). Вирусвакцина сухая культуральная ВНИВИП против вирусного энтерита гусей зарегистрирована и внедрена в ветеринарную практику. В течение 25 лет эпизоотологическая обстановка по парвовирусной инфекции гусей в большинстве хозяйств РФ и СНГ контролируется данной вакциной.

Несмотря на широкое применение аттенуированной вирусвакцины ВНИВИП проблема борьбы с этой болезнью еще остается из-за недостаточно длительного напряженного поствакцинального иммунитета гусей в течение репродуктивного периода при иммунизации их живой вакциной. Поэтому была разработана вакцина «Авипарвовак» против парвовирусной инфекции гусей инактивированная эмульгированная (патент РФ № 2420571, 2010), чтобы индуцировать у гусей образование специфических антител к парвовирусу в высоких титрах и обеспечить их трансовариальную передачу гусятам на весь репродуктивный период.

Результаты лабораторных исследований и производственных испытаний позволяют утверждать о высокой эффективности инактивированного препарата, предназначенного для специфической профилактики болезни. На основе проведенных исследований разработана нармотивная документация на вакцину. В настоящее время применение аттенуированной и инактивированной вакцин в гусеводческих хозяйствах обеспечивает сохранность 95-98\% молодняка гусей.

Таким образом, в разделах, посвященных парвовирусной инфекции гусей, представлены современные взгляды на патогенные потенции возбудителя, на источники и резервуары инфекции, охарактеризованы клинико-эпизоотологические особенности проявления болезни, приведены методы обнаружения вируса и вирусного антигена, а также рассмотрены вопросы иммунитета, активной и пассивной специфической профилактики и меры борьбы.

В настоящей работе на основе литературных данных и результатов собственных исследований подробно рассматриваются как традиционные, так и экспрессметоды индикации вирусных антигенов, к числу которых относятся МФА, ИФА, электронная микроскопия и другие. Показана возможность применения полимеразной цепной реакции (ПЦР), основанной на выявлении вирусспецифической 
нуклеиновой кислоты - ретракционного анализа ДНК. В перспективе ПЦР займет достойное место в арсенале средств и методов специфической индикации парвовирусов гусей и в диагностике вызываемой ими болезни.

Большое внимание в данной монографии уделено проблеме смешанных форм течения болезни молодняка. Приведенные материалы, несомненно, помогут практическим ветеринарным врачам осмыслить и принимать адекватные суждения о роли ассоциации различной природы возбудителей в этиопатогенезе этой формы патологии и, конечном итоге, профессионально интерпретировать обнаруживаемые в органах и тканях изменения, вызываемые вследствие наслоения или одновременного инфицирования ими молодняка гусей.

Рассматривая вопросы специфической профилактики парвовирусной инфекции, авторы обращали особое внимание на обобщение эффективности результатов испытаний предлагаемых специалистами аттенуированных и инактивированных вакцин. Оказалось, что большинство исследователей отдает предпочтение инактивированным вакцинам, их безопасность более гарантирована в связи с отсутствием возможной способности персистировать и интегрировать в геном клеток организма хозяина.

Нет сомнений в том, что в перспективе на смену живым вакцинам придут более эффективные инактивированные препараты, введение которых обеспечит привитой птице иммунологическую перестройку достаточную для того, чтобы формировался напряженный длительный поствакцинальный иммунитет.

Работая над этой монографией, авторы стремились создать такое руководство, которое бы удовлетворяло как исследователя, так и практического специалиста. Возможно, она не свободна от некоторых недостатков, авторы с благодарностью примут все критические замечания читателей. 


\section{СПИСОК СОКРАЩЕНИЙ}

АЭЭИ - аминоэтилэтиленимин

БОЕ - бляшкообразующая единица

ВНА - вируснейтрализующие антитела

ДНК - дезоксирибонуклеиновая кислота

ИПС - инкубаторно-птицеводческая станция

ИФА - иммуноферментный анализ

МКТВ - международный комитет токсономии вирусов

МФА - метод флюоресцирующих антител

ПЦР - полимеразно - цепная реакция

Пэг - клетки почек эмбриона гусей

РдП - реакция диффузионной преципитации

PH - реакция нейтрализации

РСК - реакция связывания комплемента

РТГА - реакция торможения гемагглютинации

ТцД $50 / \mathrm{cm}^{3}$ - 50\%-ная тканевая цитопатогенная доза в $1 \mathrm{~cm}^{3}$

цпД - цитопатогенное действие

цПэ - цитопатический эффект

ELISA - enzyme - linked immunosorbent assay

(твердофазный иммуноферментный анализ)

Ig G, Ig M - иммуноглобулины G и M

$\mathrm{LD}_{50}-50 \%$ - ная летальная доза

Ig - логарифм по основанию 10

IgКин - константа скорости инактивации

$\log _{2}$ - логарифм по основанию 2

PI c - бляшки с четкими краями, врнутри детриты клеток

$\mathrm{Pgl}$ - патогенность для гусят

Pgle - патогенность для гусиных эмбрионов

Rct - reproductive capacity temperature

(способность к репродукции при определенной температуре)

STC - бляшки мелких размеров

SPF - свободные от патогенной флоры 


\section{СПИСОК ЛИТЕРАТУРЫ}

1. Акулов, А.В., Контримавичус Л.М. Патоморфологические изменения у гусят при вирусном энтерите // Тр. ВИЭВ. - 1975. - Т.43. - С.384-392.

2. Байдевлятов, А.Ф. Заболевание гусей невыясненной этиологии // Ветеринария. - 1966. - № 4. - С.42-44.

3. Белецкая, А. Вирусный энтерит - под контроль // Птицеводство. - 2003. - №8. - С.17.

4. Белецкая, А.В., Безрукавая И.Ю., Грибкова Н.П. Разработка и испытание вакцины против вирусного энтерита гусей // Птахівництво: міжвід. темат. наук. зб. (Матеріали IV Укр. конф. по птахівництву). - Харків., 2003. - Вип. 53. - C. 520-525.

5. Білецька, Г.В., Стегній Б.Т., Безрукава І.Ю., Ізоляція патогенного вірусу ентериту гусей // Прогрессивні технологіі ветеринарноі медицини в промисловому птахівництві XXI ст.: тез. докл. міжнарод. конф. - Киів., 2000. - С. 16-17.

6. Божко, О. Гусеводство Харьковщины // Птицеводство. - 1988. - №10. - C.22-23.

7. Бондаренко, А.Ф., Капитанаки М.В. Вирусный энтерит на Кубани // Сб. науч. тр. СКЗНИВИ.- Краснодар, 1975а. - С.132-135.

8. Бондаренко, А.Ф., Капитанаки М.В., Сажнев В.Н. Изучение массовых заболеваний гусят на гусеводческих фермах Краснодарского края // Сб. науч. тр. СКЗНИВИ. - Краснодар, 1975. - С.135-138.

9. Бондаренко, А.Ф., Капитанаки М.В. Течение смешанной инфекции у гусят // Ветеринария.- 19756. - №2. - С. 63-64.

10. Бондаренко, А.Ф. Об этиологии вирусного энтерита гусят // Болезни птиц: тр. СКЗНИВИ. - 1977. - С.67-69.

11. Бондаренко, А.Ф. Усовершенствование методов диагностики профилактики вирусного энтерита гусей: автореф. дис. ... канд. вет. наук: 16.00.03. / Бондаренко А.Ф. - Краснодар, 1982. - 18 с.

12. Борисова, И.А. Разработка технологии изготовления и контроля инактивированной вакцины против ньюкаслской болезни и метапневмовирусной инфекции птиц: дис. ... канд. биол. наук: 03.02.02. / Борисова И.А. - Владимир, 2008. - 167 c.

13. Борисов, В.В. Борисов А.В., Старов С.К. Инактивированные вакцины - возможные варианты применения в промышленном птицеводстве // Матер. конф. по птицеводству. - М.,2003. - С.208-209.

14. Бородина, О.В. Разработка инактивированной эмульсионной вакцины против пастериллеза птиц: дис. ... канд. биол. наук: 03.00.07., 03.00.23. / Бородина О.В. - Ульяновск, 2006. - 122 с. 
15. Вертинский, К.И., Бессарабов Б.Ф., Стрельников А.П., Куриленко А.Н., Преображенская Э.А. Малоизученное вирусное заболевание гусей / Ветеринария. - 1973а. - №3. - С.64-66.

16. Вертинский, К.И., Стрельников А.П., Куриленко А.Н. Клинико-анатомическая характеристика малоизученного вирусного заболевания гусей // Тр. 5-ой Всесоюзной конф. по патолог. анатом. ж-х. - МВА. - 1973б. - С.179-181.

17. Вертинский, К.И. Сюрин В.Н., Сосов Р.Ф., Стрельников А.П., Куриленко А.Н., Преображенская Э.А. Чувствительность некоторых видов животных к возбудителю малоизученного заболевания гусей // Вопр. вет. науки и практики: сб. научн. труд. - 1974. - т.73. - ч.1. - С.139-142.

18. Ветеринарная микробиология: учеб. пособие под редакцией Рево М.В., Жукова М.Д. / Сельхозгиз, М., 1958.

19. Вирусные болезни животных: учеб. пособие под редакцией Сюрина В.Н. и др. - Москва: ВНИТИБП, 1998. - С.17-20.

20. Гадиев, Р.Р., Фаррахов А.Р. Совершенствование технологии содержания гусей в селекционных гнездах // Матер. XVII Междунар. конф.: «Инновационные разработки и их освоение в промышленном птицеводстве». - Сергиев Посад, 2012. - С. 46-47.

21. Гадиев, Р.Р., Фаррахов А.Р. Эффективность использования гидропонной зелени в рационах гусей при различной технологии // Матер. XVII Междунар. конф.: «Инновационные разработки и их освоение в промышленном птицеводстве». - Сергиев Посад, 2012. - С. 158-160.

22. Держи, Д., Контримавичус Л.М., Надточей Г.А. Культуральные свойства, антигенное родство и морфология различных штаммов вируса энтерита гусей // Доклады ВАСХНИЛ.- 1975. - № 7. - С.36-37.

23. Джавадов, Э.Д. Вирус-индуцированные иммуносупрессии и способы их предупреждения в промышленном птицеводстве: дис. ... д-ра. вет. наук:16.00.03 / Джавадов Э.Д. - Москва., 2004. - 345 с.

24. Джавадов, Э.Д. Вихрева И.Н., Дмитриева М.Е., Дубовой А.С., Самусева Г.Н. Профилактика болезней птиц инактивированными вакцинами серии «Авикрон» // Матер. Междунар. конг. - СПб, 2009. - С.30-31.

25. Жаркова, И.П., Гришина Д.С. Качественная оценка генофонда пород гусей // Матер. XVII Междунар. конф.: «Инновационные разработки и их освоение в промышленном птицеводстве». - Сергиев Посад, 2012. - С. 61-63.

26. Ельников, Е.В. Технология изготовления ассоциированной инактивированной вакцины против ньюкаслской болезни и реовирусного теносиновита птиц: автореф. дис. ... канд. веет. наук: 16.00.03. / Ельников Е.В. - Владимир, 2003. -24 c. 
27. Иващенко, В.Г. Усовершенствование диагностики, мер борьбы и профилактики вирусного энтерита гусей : автореф. дис. ... канд. вет. наук: 16.00.03. / Иващенко В.Г. - Л., 1986. - 25 с.

28. Контримавичус, Л.М., Семилит И.Л., Клейхменева Л.Н., Карпов Г.М. Изучение массового заболевания гусят невыясненной этиологии и опыт его профилактики (по материалам 1963-1965гг.) // Тр. Горьковской НИВС. - 1968. - № 3. - С.33-39.

29. Капитанаки, М.В. Чечула Л.Д. Эпизоотия вирусного энтерита на Кубани // Бюл. НТИ / Краснодарская НИВС. - 1970. - Вып.2. - С.82-85.

30. Капитанаки, М.В., Бондаренко А.Ф., Чечула Л.Д. К вопросу этиологии энзоотического энтеро-кутикулита гусят // Бюл. НТИ / Краснодарская НИВС. 1970. - Вып.2. - С.79-82.

31. Капитанаки, М.В., Бондаренко А.Ф., Чечула Л.Д. Вирусный энтерит гусят // Ветеринария. - 1971. - № 7. - С.58-59.

32. Капитанаки, М.В., Чечула Л.Д., Манохин А.В. Лечение гусят при вирусном гастроэнтерите // Птицеводство. - 1971. - № 12. - С.46-47.

33. Капитанаки, М.В., Чечула Л.Д., Манохин А.В. Опыт применения лечебно-профилактических средств при инфекционном гастроэнтерите гусей // Науч. тр. Краснодарская НИВС. - 1972. - Т.5. - С.28-27.

34. Капитанаки, М.В., Чечула Л.Д. О вирусном гастроэнтерите гусят // Сб. тр. / ВНИВИП. - 1976. - Вып.11. - С.231-236.

35. Кислюк, С. Оптимальный набор кормовых добавок в условиях повышения цен на сырье // Птицеводство. - 2008. - № 7. - С.21-22.

36. Ковацкий, Н. Резервы гусеводства // Птицеводство. - 1988. - № 10. C.10-13.

37. Комиссаров, К.П. Диагностика вирусного энтерита гусей с помощью реакции диффузионной преципитации в агаровом геле и метод ФА // Актуальные вопросы вет. вирусологии: тез. докл. 6 Всесоюз. вет. вирусн. конф. (1719 ноября 1976 г.). - Ч.1. - С.164-165.

38. Кондаков, М.П. Патологоанатомические изменения у гусят при вирусном энтерите // Сб. науч. тр. Дон. СХИ. - 1973. - Т.8, вып.1. - С.139-140.

39. Кондаков, М.П., Фадин В.С. Патоморфологические изменения у гусят при вирусном энтерите // Тр. 5 Всесоюз. науч. метод. конф. по патолог. анатомии животных (Тбилиси, 1972 г.) / МВА. - М., 1973. - С.37-40.

40. Кондаков, М.П., Фадин В.С. Морфологическая реакция у гусят на введение крови переболевших вирусным энтеритом гусей // Материалы 6 Всесоюз. конф. по патолог. анатомии животных. - Тарту, 1977. - Т.2. - С.158-160.

41. Контримавичус, Л.М., Семилит И.Л., Клейхменева Л.Н., Карпов Г.М., Козлова Е.И., Кудрявцев Ф.С. Результаты изучения инфекционного энтерита гусят // Ветеринария. - 1966. - № 12. - С.34-36. 
42. Контримавичус, Л.М., Майборода А.Д. Предварительные данные о культивировании вируса энтерита гусят в культуре ткани // Бюл. ВИЭВ. - 1968. - Вып.4. - С.11-12.

43. Контримавичус, Л.М. Инфекционный энтерит гусят // Тр. ВИЭВ. - М., 1968. - T.35. - С.292-301.

44. Контримавичус, Л.М. Инфекционный энтерит гусят // Эпизоотология. - М.: Колос, 1969. - С.355-356.

45. Контримавичус, Л.М. Некоторые биологические свойства вируса энтерита гусят // Бюл. ВИЭВ. - 1970а. - Вып.7. - С.32-35.

46. Контримавичус, Л.М. К эпизоотологии вируса энтерита гусят // Бюл. ВИЭВ. - 1970б. - Вып.7. - С.36-38.

47. Контримавичус, Л.М. Вирусный энтерит гусей (Enteritis virosa anserculorum) // Болезни птиц. - М.: Колос,1971. - С.77-82.

48. Контримавичус, Л.М. Некоторые вопросы инфекционной патологии гусят // Ветеринария. - 1972. - № 8. - С.66-68.

49. Контримавичус, Л.М., Шуляк А. Распространение Enteritis virosa anserculorum у гусят и ГЭ // Передовой науч.-производ. отчет в птицеводстве: экспресс-информ. - 1973. - № 5. - С.28-30.

50. Контримавичус, Л.М. К лабораторной диагностике вирусного энтерита гусят // Ветеринария. - 1974а. - № 8. - С.108-110.

51. Контримавичус, Л.М. Вирусный энтерит гусей и меры борьбы с ним // Птицеводство. - 19746. - № 6. - С.45-46.

52. Контримавичус, Л.М. Сравнительная характеристика штаммов вируса, выделенных от больных энтеритом гусят // Тр. ВИЭВ. - 1975а. - Т.43. - С.212-224.

53. Контримавичус, Л.М. Оценка активности гипериммунных сывороток против вируса энтерита гусей // Ветеринария. - 19756. - № 1. - С.37-38.

54. Контримавичус, Л.М., Кишари Я. Стандартизация сывороток против вирусного энтерита гусей // Ветеринария. - 1976. - № 8. - С.50-51.

55. Контримавичус, Л.М. Значение идентификации парвовируса в диагностике вирусного энтерита гусей // Науч. основы ветеринарно-санитарных мероприятий в промышленном птицеводстве: тез. докл. Всесоюз. конф. (3-6 октября 1977 г.). - Кишенев, 1977. - С.35-37.

56. Контримавичус, Л.М. Вирусный энтерит гусей: дисс ... д-ра вет. наук: 16.00.03. / Контримавичус Л.М. - М., 1978. - 320 с.

57. Контримавичус, Л.М., Макогон В.Ф., Навроцкий В.В. Эпизоотологические и клинико-анатомические признаки вирусного энтерита гусят // Ветеринария. - 1980. - № 7. - С.34.

58. Контримавичус, Л.М., Суворов А.М. Усовершенствование диагностики вирусного энтерита гусей // Ветеринария. - 1982. - № 11. - С.67-68. 
59. Корнеева, В.И., Фадин В.С., Куриленко А.В. Лабораторная диагностика вирусного энтерита на гусиных эмбрионах // Материалы I Сибирской зональной науч.-произв. конф. - Омск, 1973. - С.27-30.

60. Кравченко, Т.М., Липская В.В. К этиологии массового заболевания гусят // Ветеринария. - 1966. - № 8. - С.88-90.

61. Крылов, М.В., Терюханов А.Б. Инфекционные и инвазионные болезни водоплавающих птиц // Л.: Колос, 1975. - С.14-18.

62. Макогон, В.Ф. Массовое заболевание гусят энтеритом // Ветеринария. - 1974. - № 8. - С.55-56.

63. Макогон, В.Ф., Болдырев Д.Н., Поворознюк В.Ф. Захворювання гусенят ентеритом у господарствах Кримськоі областні // Ветеринария. - 1975. Вип.40. - С.58-61.

64. Макогон, В.Ф. Профилактика вирусного энтерита // Птицеводство. 1979. - № 3. - C.42-43.

65. Малушко, В.В. Щеглова И.В., Комиссаров К.П., Фадин В.С., Корнеева В.И., Трефилов Б.Б. Выделение вируса энтерита гусят и изучение его антигенной активности // Лечение и проф. болезней c.-х. ж-х и птиц: матер. научнопроизв. конф. - Л., 1975. - С.3.

66. Малушко, В.В. Изучение этиологии, разработка мер борьбы с малоизвестными вирусными болезнями водоплавающей птицы // Сб. рефератов НИР и ОКР. - 1976. - № 3. - С.30.

67. Малушко, В.В. Кудрявцев Ф.С., Пожалова Р.Г. Курганский Т.А., Трефрилов Б.Б. Культивирование вируса энтерита гусей в перевиваемых линиях клеток // Научн. основы вет.- профил. меропр. в промыш. птицеводстве. - Кишенев, 1977. - С.37-39.

68. Малушко, В.В., Иващенко В.Г., Щеглова И.В., Трефилов Б.Б. Вирусный энтерит и меры борьбы с ним // Актуальные вопросы вет. вирусологии: тез. докл. 5 Всесоюз. конф. - 1980. - С.32.

69. Малушко, В.В.Вирусный энтерит гусей // Справочник вет. врача птицеводческих предприятий. - М.: Колос, 1982. - С.103-105.

70. Малушко, В.В., Трефилов Б.Б., Контримавичус Л.М., Щеглова И.В., Фадин В.С., Бондаренко А.Ф. Эпизоотологическое состояние гусеводческих хозяйств, профилактика и меры борьбы с вирусным энтеритом гусей // Ветеринария. -1983.

71. Малушко, В.В., Трефилов Б.Б., Щеглова И.В., Иващенко В.Г. Предупреждение вирусного энтерита гусей // Птицеводство. - 1984. - № 5. - С.31-32.

72. Малушко, В.В., Трефилов Б.Б. Вирусный энтерит гусей // В кн.: «Профилактика наиболее опасных вирусных болезней птиц». - Кишенев, 1985. С.139-154. 
73. Малушко, В.В., Трефилов Б.Б., Щеглова И.В. Вирусвакцина сухая культуральная ВНИВИП против вирусного энтерита гусей // Технич. условия 10-0940-90. - 1990. - 21 с.

74. Малушко, В.В., Трефилов Б.Б. Болезни гусей и их профилактика // Птицеводство. - 1992. - № 5. - С.32-36.

75. Малушко В.В, Трефилов Б. Б., Щеглова И.В, Пажалова Р.Г. Штамм Goose parvovirus для приготовления вакцинных препаратов против вирусного энтерита гусей // Патент РФ № 1499917, 1993.

76. Мамаев, В. Ковацкий Н., Кабанова О. Прижизненная ощипка гусей // Птицеводство. - 1998. - № 10. - С.23-24.

77. Маслов, Д.В. Серологическая диагностика вирусного энтерита гусей методом иммуноферментного анализа: автореф. дис. ... канд. вет. наук: 16.00.03. / Маслов Д.В. - СПб, 2006. - 17 с.

78. Маслов, Д.В., Никитина Н.В., Трефилов Б.Б. Диагностика вирусного энтерита гусей методом иммуноферментного анализа // Новые фармакологические средства в ветеринарии: матер. XVIII Междунар. межвуз. науч.практ. конф. СПбГАВМ. - СПб, 2006. - 57 с.

79. Махалов, А.Г. Научное обоснование использования биологически активных веществ в кормлении гусей: автореф. дис. ... д-ра с/х наук / СергиевПосад, 2008. - 43 с.

80. Мельников, Н.М., Фадин В.С. Смешанная инфекция вирусного энтерита и сальмонеллеза гусят// Матер. І Сибир. зональной науч.- производ. конф. - Омск, 1973.

81. Михайлов, А.О. Чувствительность парвовируса гусей к формальдегиду и димерэтиленимину // Вопросы нормативно-правового регулирования в ветеринарии. - СПб, 2009. - № 4. - С.104-106.

82. Михайлов, А.О. Иммунобиологические свойства инактивированной вакцины против вирусного энтерита гусей: автореф. дис...канд. вет. наук: 16.00.03./ Михайлов А.О. - СПб, 2010. - 22 с.

83. Монашон, Т. Изучение, проведенное научно-исследовательской станцией «Артигер» по улучшению выращивания гусей // Тр. XIII Всемир. конгресса по птицеводству. - 1966.

84. Музыка, Н.Н., Белецкая А.В., Безрукавая И.Ю., Изучение иммунного статуса гусей при вирусном энтнрите серологическими методами // Птахівництво: міжвыд. темат. наук. зб. (за матеріалами V укр. конф. по птахівництву з міжнарод. участю). - Харьков, 2004. - Вип. 55. - С.546-550.

85. Надточей, Г.А., Контримавичус Л.М., Петелина Е.А. Адаптация вируса энтерита гусей и его основные классификационные свойства // Бюлл. ВИЭВ. - 1975. - вып.21. - С.28-31. 
86. Недобуга, С. С минимальными затратами // Птицеводство. - 1988. № 10. - С.17-18.

87. Малушко, В.В., Кудрявцев Ф.С., Пожалова Р.Г., Комиссаров К.П., Щеглова И.В., Трефилов Б.Б. Об антигенном различии штаммов-изолятов вирусного энтерита гусей // Актуальные вопр. вет. вирусологии: тез. докл. 6 Всесоюз. вет. вирусолог. конф. (17-19 ноября 1976 г.). - т. 1. - Владимир, 1976. - С.165-167.

88. Оноприенко, Я. Растет поголовье гусей // Птицеводство. - 1988. - № 10. - С.21-22.

89. Паникар, И.И., Белицкий Б.И. Паникар, И.И. Заболевание гусят с признаками энцефаломиэлита // Вісник сільстко-господ. науку. - 1971. - № 3. С.105-107.

90. Петелина, E.A. Морфологические изменения в энтероцитах тонкого отдела кишечника гусят при вирусном энтерите // Бюл. ВИЭВ. - М., 1983. Вып.50. - С.58-60.

91. Петелина, E.A. Биологические и физико-химические свойства вируса энтерита гусей: автореф. дис. ... канд. вет. наук: 16.00.03 / Петелина Е.А. - М., 1984. -23 c.

92. Пожалова, Р.Г. Репродукция вируса энтерита гусей в клеточных культурах // Тез.докл. 6 Всесоюз. вирус. конф. 17-19 ноября 1976 г. - Владимир, 1976. - 4.I. - С.132-134.

93. Преображенская, Э.А. Изучение и классификация возбудителя малоизученного заболевания гусей // Тез. докл. Всесоюз. межвуз. конф. по вет. вирусол. - М., 1973а. - ч.ІІ. - С.100.

94. Преображенская, Э.А., Куриленко А.Н., Сюрин В.Н. Культивирование вируса, выделенного от гусят Горьковской области // Тез. докл. Всесоюз. межвуз. конф. по вет. вирусол. - М., 1973б. - ч.ІІ. - С.101.

95. Рак, И., Стрекалова Л., Доброродный А. Наш многолетний опыт // Птицеводство. - 1988. - № 10. - С.18-21.

96. Ройтер, Я.С., Соловьев В.Ю., Макулин А.А. Состояние и основные направления работы с линдовской породой гусей // Матер. XVII Междунар. конф.: «Инновационные разработки и их освоение в промышленном птицеводстве». - Сергиев Посад, 2012. - С.95-97.

97. Руднякова, В.Г. Вирусный энтерит гусят в Новосибирской области // Профилактика болезней с.-х. животных. ВАСХНИЛ. Сиб. отд. - 1976. - Вып.1. - С.83-86.

98. Руководство по ветеринарной вирусологии / Сюрин В.Н. - М.: Колос, 1966. - С.141-185, 206, 207.

99. Суворов, А.М. Антигенные свойства парвовируса гусей // Бюл. ВИЭВ. - М., 1982. - Вып.48. - С.16-18. 
100. Суворов, А.М. Антигенные и иммуногенные свойства аттенуированных штаммов вируса энтерита (парвовируса) гусей : автореф. дис. ... канд. вет. наук // М., 1986. - 22 с.

101. Суханова, С.Ф., Махалов А.Г. Голозерный ячмень различных сортов в составе комбикормов для гусят- бройлеров // Матер. XVII Междунар. конф.: «Инновационные разработки и их освоение в промышленном птицеводстве». - Сергиев Посад, 2012. - С.264-266.

102. Тобоев, Г. Оценка мясных качеств гусей линдовской породы // Птицеводство. - 2008. - № 7. - С.26-27.

103. Тресрилов, Б.Б. Антигенная активность и родство штаммов-изолятов вируса энтерита гусят // Перед. науч.-производ. опыт в птицеводстве.-М.,1976. - вып. 12 (60). - С.26-27.

104. Трефилов, Б.Б. Патогенность и терморезистентность вируса энтерита гусей// Тез. докл. X1X конф. молодых ученых и аспирантов по птицеводству. - Загорск, 1976. - С.59-61.

105. Трефилов, Б.Б. Испытания формолвакцины против вирусного энтерита гусей в производственных условиях // Перед. науч.-производ. опыт в птицеводстве. - М., 1982. - 3(III). - С.40-41.

106. Трефилов, Б.Б., Щеглова И.В. Биологические свойства вируса энтерита гусей // Компл. система вет. меропр. в птицеводстве - резерв повышения эффективности производства: тез. докл. Всесоюз. научно-произв. конф. - Л., 1989. - С.36-37.

107. Трефилов, Б.Б. Клонирование вируса энтерита гусей // Компл. система вет. меропр. в птицеводстве - резерв повышения эффективности производства: тез. докл. Всесоюз. научно-произв. конф. - Л., 1989. - С.37-39.

108. Трефилов, Б.Б. Разработка средств профилактики вирусного энтерита гусей // Ветеринария. - 1990. - № 6. - С.6.

109. Трефилов, Б.Б. Производственные испытания вирусвакцины ВНИВИП против вирусного энтерита гусей // Система мероприятий обеспечения эпизоотического благополучия птицеводческих предприятий: сб. науч. тр.СПб., 1993. - С.41-49.

110. Трефилов, Б.Б. Гуморальный и клеточный иммунитет при сочетанном применении вирусвакцины ВНИВИП притив ВЭГ с иммуномодуляторами // Вирусные болезни с.-х. животных: тез. докл. Всерос. научн. - практ. конф. Владимир, 1995. - С.278.

111. Трефилов, Б.Б. Специфическая профилактика вирусного энтерита гусей // Вирусные болезни с.-х. животных: тез. докл. Всерос. научн. - практ. конф. - Владимир, 1995. - С.277. 
114. Трефилов, Б.Б. Профилактика вирусного энтерита гусей // Информац. Листок. - СПб - Ломоносов, 1996. - № 1 - 96.

115. Трефилов, Б.Б. Эпизоотологические особенности вирусного энтерита гусей // Ветеринарная профилактика в промышленном птицеводстве: сб. науч. тр. - СПб-Ломоносов, 1996. - С.48-56.

116. Трефилов, Б.Б. Проблема вирусного энтерита гусей в промышленном птицеводстве // Материалы науч.-производ. конф., посвящ. 190-летию высш. вет. образования в России и 100-летию вет. науки. - СПб., 1998. -Т.2. - C.99.

117. Трефилов, Б.Б. Разработка и внедрение средств диагностики и специфической профилактики наиболее опасных вирусных болезней птиц (инфекционный ларинготрахеит, вирусный энтерит гусей, реовирусный теносиновит): дис. ... д-ра вет. наук: 16.00.03./ Трефилов Б.Б. - СПб., 2000. - 42 с.

118. Трефилов, Б.Б., Маслов Д.В., Кривенцев К.А. Изучение культуральных свойств вируса энтерита гусей // Новое в эпизоот., диагност. и профил. инфек. и незаразных болезней птиц в промыш. птицеводстве: матер. междунар. юбил. науч.-практ. конф., 14-16 сентября 2004. - СПб - Ломоносов, 2004. - C.106-107.

119. Трефилов, Б.Б., Коровин Р.Н., Придыбайло Н.Д. Основы профилактики вирусных болезней птиц // Матер. Междунар. юбил. научно-прат. конф.СПб, 2004. - С.21-30.

120. Трефилов, Б.Б. , Никитина Н.В., Явдошак Л.И., МасловД.В., Кривенцев К.А., Михайлов А.О. Вирусный энтерит гусей (диагностика и профилактика) // Актал. проб. вет. мед.: научно-прак. конгр. 24-25 авг.-СПб, 2007. - С.211213.

121. Трефилов, Б.Б., Никитина Н.В., Маслов Д.В., Явдошак Л.И., Михайлов A.O. Основы профилактики вирусного энтерита (парвовирусной инфекции) гусей // Новое в диагностике и профилактике болезней птиц: матер. научно-практ. конф. 3-4 июня 2008 г. - СПб, Ломоносов, 2008. - С.87-93.

122. Трефилов, Б.Б., Михайлов А.О. Генетические маркеры вакцинного клона парвовируса гусей // Достиж. в соврем. птицеводстве: исследования и инновации: матер. X1V конф. - Сергиев Посад, 2009. - С.400-402.

123. Трефилов, Б.Б., Никитина Н.В., Михайлов А.О. Усовершенствование средств специфической профилактики парвовирусной инфекции гусей // Матер. междунар. агропромыш. конгресса. - СПб, 2009. - С.40.

124. Трефилов, Б.Б., Никитина Н.В., Михайлов А.О., Явдошак Л.И. Вакцина и способ вакцинации против парвовирусной инфекции гусей. Патент РФ №2420571, 2010. 
125. Трефилов, Б.Б., Никитина Н.В., Михайлов А.О., Явдошак Л.И. Профилактика парвовирусной инфекции гусей // Матер. XVII Междунар. конф.: «Инновационные разработки и их освоение в промышленном птицеводстве». - Сергиев Посад, 2012. - С.620-621.

126. Фадин, В.С., Дедкова Л. Применение сыворотки от гусей-реконвалесцентов при инфекционном энтерите гусят // Земля Сибирская Дальневосточная. - 1970. - № 7. - С.35.

127. Фадин, В.С., Романовская А., Вронская М. Цитратная кровь гусей-реконвалесцентов в профилактике вирусного энтерита // Птицеводство. - 1971. - № 5. - C.45.

128. Фадин, В.С. Вирусный энтерит гусят // Земля Сибирская Дальневосточная. - 1972. - № 5. - С.32.

129. Фадин, В.С. Некоторые данные по эпизоотологии вирусного энтерита гусят // Итоги науч. исследований и рекомендаций по профилактике болезней птиц в хозяйствах промышленного типа: тез. докл. (Куйбышев, 12-15 ноября 1973 г.). - 1973 .

130. Фадин, В.С. Погуляева Л.В., Жданова М.Е. Экспериментальное заражение гусят вирусным энтеритом // Профилактика заразных и незаразных заболеваний животных в Сибири. - 1973. - С.122-125.

131. Фадин, В.С., Мельников Н.М. Профилактика вирусного энтерита цитратной кровью // Науч. тр. Омского вет. ин-та. - 1973. - Т.29, вып. 3. - С.27-30.

132. Фадин, В.С. Методика диагностики и профилактики вирусного энтерита гусят // Вет. профилактика болезней с.-х. животных в Сибири. - Новосибирск, 1973б. - С.157-161.

133. Фадин, В.С. Смешанная инфекция вирусного энтерита и сальмонеллеза гусят // Матер. 1 Сибир. зонал. науч.-производ. конф. - Омск, 1973в. C.27-30.

134. Фадин, В.С., Лапин Б.И. Эпизоотология вирусного энтерита гусят // Земля Сибирская Дальневосточная. - 1974. - № 10. - С.36-37.

135. Фадин, В.С. Производственные испытания цитратной крови гусей -реконвалесцентов в профилактике вирусного заболевания гусят // Сб. науч. работ СибНИВИ. - 1975а. - Вып.22. - С.168-175.

136. Фадин, В.С. Вопросы эпизоотологии и диагностики вирусного заболевания гусят // Сб. науч. работ СибНИВИ. - 19756. - Вып.22. - С.160-167.

137. Фадин, В.С., Куриленко А.В., Корнеева В.И. Вопросы этиологии и профилактики вирусного энтерита гусят в птицеводческих комплексах // Профил. инфекц. болезней ж-х в промыш. комплексах. - Омск,1976. - С.107-108.

138. Фадин, В.С., Куриленко А.В., Корнеева В.И. Вирусоносительство при вирусном энтерите гусей // Сб. науч. работ СибНИВИ. - 1977. - Вып. 29. - С.61-62. 
139. Фадин, В.С. Материалы по эпизоотологии вирусного энтерита // Науч. основы вет.-профилакт. мероприятий в промышленном птицеводстве: тез. докл. Всесоюз. конф. (3-6 окт. 1977 г.). - Кишинев, 1977.

140. Фадин, В.С. Экспериментальный вирусный энтерит гусят // Сб. науч. работ СибНИВИ. - 1979а. - Вып. 34. - С.134-137.

141. Фадин, В.С. Экономический ущерб при вирусном энтерите гусей и экономическая эффективность серопрофилактики // Сб. науч. работ СибНИВИ. - 1979б. - Вып. 34. - С.138-141.

142. Фадин, В.С. Профилактика вирусного энтерита гусят // Актуальные вопросы вирусологии: тез. докл. 5 Всесоюз. конф. - Казань, 1980. - С.31-32.

143. Фадин, В.С., Куриленко В.В. Методы инактивации вируса энтерита гусей // Хронические инфекции животных: сб. научн. трудов. - Новосибирск, 1981. - С.126-129.

144. Фисинин, В.И. Птицеводство России в 2011 году: состояние и перспективы инновационного развития до 2020 года // Матер. XVII Междунар. конф.: «Инновационные разработки и их освоение в промышленном птицеводстве». - Сергиев Посад, 2012. - С.7-17.

145. Фисинин, В.И., Гадиев Р.Р., Фаррахов А.Р., Галина Ч.Р. Эффект гетерозиса в гусеводстве // Матер. XVII Междунар. конф.: «Инновационные разработки и их освоение в промышленном птицеводстве». - Сергиев Посад, 2012. - С.114-116.

146. Циновый, А.В. Разработка ИФА - диагностикума для определения антител к вирусу энтерита гусей // VI-й Междунар. вет. конгресс по птицеводству (26-29 апреля 2010). - М., 2010. - С.90-97.

147. Цой, В.Г. Стандарт качества перо-пуховых изделий // Матер. XVII Междунар. конф.: «Инновационные разработки и их освоение в промышленном птицеводстве». - Сергиев Посад, 2012. - С.485-487.

148. Чаленко, В.М. Оценка скрещивания гусей в условиях гусеводческого хозяйства Буденовского района Ставропольского края // Матер. XVII Междунар. конф.: «Инновационные разработки и их освоение в промышленном птицеводстве». - Сергиев Посад, 2012. - С.119-121.

149. Чекшиев, В.М., Фадин В.С. Влияние гипериммунизации гусей вируссодержащей аллантоисной жидкостью на белковый спектр крови // Сб. науч. работ / СибнИВИ. - 1976. - Вып. 26. - С.99-104.

150. Чечула, Л.Д., Капитанаки М.В. Испытание цитратной крови переболевших гусят и гусынь, желудочного сока с фуразолидоном и уросала при вирусном гастроэнтерите // Сельск. Зори. - 1971. - № 8. - С.53.

151. Шлапаченко, А., Гострик В., Грабовский П. Профилактика энтерита гусят // Птицеводство. - 1981. - № 6. - С.34. 
152. Щеглова, И.В., Малушко В.В. Чувствительность возбудителя к некоторым химиотерапевтическим препаратам // Передовой науч.-производ. опыт в птицеводстве: экспресс-информ. - 1975. - № 4. - С.26.

153. Щеглова, И.В., Иващенко В.Г., Трефилов Б.Б. Применение гипериммунных сывороток для профилактики вирусного энтерита гусей // Передовой науч.- производ. опыт в птицеводстве: экспресс-информ.- М. 1980. - С.30-31.

154. Щеглова, И.В., Иващенко В.Г. Эффективность живой экспериментальной вакцины против вирусного энтерита гусей // Система мероприятий по обеспечению эпизоотического благополучия и рентабельности птицеводческих предприятий : тез. докл. науч.-производ. конф. (окт. 1985 г.). - Ломоносов, 1985. - Ч.2. - С.54-55.

155. Эльберт, Г., Сниткин М. Перспективная технология // Птицеводство. - 1988. - № 10. - С.14-17.

156. Эпизоотология с микробиологией: учебное пособие под редакцией М.С.Ганнушкина // Москва: изд. Колос, 1965.

157. Юрко, П.С., Белецкая А.В., Безрукавая И.Ю., Грибкова И.П. Специфическая профилактика вирусного энтерита гусей. Живая и инактивированная вакцина // VI-й Междунар. вет. конгресс по птицеводству (26-29 апреля 2010). - М., 2010. - С.86-90.

158. Юрко, П.С., Безрукава І.Ю., Білецька Г.В. Розробка окремих технологічних режимів для конструювания інактивованоі вакцини проти вірусного ентериту // Ветеринарна медицина: міжвід. темат. наук. зб. / ІЕКВМ. - Харків, 2005. - Вип. 85. - С.1160-1163.

159. Ahmed, A.A.S. Wirusinfectionen bei Gansen // Berlin und Munchen tierart. Wochenschr. - 1973. -Jg. 86. - № 2. - P.28-32.

160. Anderson, M. J., Pattison J. R. The human parvovirus // Arch. Virol. 1984. - Vol. 82. - № 3/4. - P.137-148.

161. Astell, C. R., Thomson M., Chow M. B. Structure and replication of minute virus of mice DNA // Cold Spring Harbor Symp. Quant. Biol. - 1983. - Vol. 47. - № 2. - P.751-762.

162. Astell, C. R., Thompson M., Merchlinsky M. The complete DNA sequence of minute virus of mice, an autonomous parvovirus // Nucl. Acids Res. - 1983. - Vol. 2. - № 4. - P.999-1018.

163. Banerjee, P. T., Olson W. H., Allison D. P. Electron microscopic comparison of the sequenses of single-stranded genomes of mammalian parvoviruses by heteroduplex mapping // J. Mol. Biol. - 1983. - Vol. 166. - № 3. - P.257-272.

164. Bates, R. C., Snyder C. E., Banerjee P.T. Autonomous parvovirus Lu3 encapsidates equal amounts of plus minus DNA strands // J. Virol. - 1984. - Vol. 49. - № 2. - P.319-324. 
165. Bergmann, V. Pathologie und elektroneumikroskopischer virusnachweis im Gevebe bei der Derzsyschen Krankheit (Parvovirus Infection) der Gössel // Arch. exper. Vet. Med. - 1987. - Jg. 41. - № 2. - P.212-221.

166. Bernath, S., Szalai F. Visgalator libapipek kozott 1969 - ben jelentrezett megbetegedes koroktananak tisztazasara. 1. Fertozesi kiserletek // Magyar Allatorv. Lapja. - 1970. - T.25. - № 10. - P.531-536.

167. Bernath, S., Pethes G. A busa Fabrici eltavolitasanak hatasa kislibar virus okoztra verömleses bel-es vesegyalladas ban megnyilvenullo betegsegenek korfe. lodeseben // Magyar Allatorv. Lapja. - 1971. - T.26. - № 7. - P.366-367.

168. Bidin, Z. Cajavec S., Sladic D. Protection of broiler breeders by an inactivated combined water-in-oil-in water viral vaccine // Acta Vet. Hung. - 1998. - Vol. 46. - № 1. - P.25-34.

169. Bouquet, J.F., Rousselot - Pailley D., Tixier G., Moreau Y. Derzsy disease immunity: vaccination of breeder geese with living vaccine and maternal antibodies in goslings// Europ. Waterfowl Dis. Symp., Weybridge, 24-27 august, 1981.

170. Brown, K.E., Green S.W., Young N.S. Goose parvovirus - an autonomous member of the dependovirus genus? // Virology. - 1995. - Vol. 210. - P.283-291.

171. Carter, B. J., Laughlin C.A., Marcus-Secura C.J. Parvovirus transcription // Parvoviruses. - N. Y.; London. - 1984. - P.153-207.

172. Carter, B.J., Laughlin C.A. Adeno-associated virus defectiveness and the nature of the adenovirus helper function // Parvoviruses. - N. Y.; London. - 1984. - P.67-128.

173. Cleef, S.A.M., Van Miltenburg J. Th. Sen ernstige acta verlopende virusziekte bij ganzekuikens, gepaard gaande met grote sterfte // Tijdschr. diergeneeskunde. - 1966. - Bd.91. - № 6. - P.372-382.

174. Coudert, M., Dannacher G., Peillon M., Sabatut R., Ferlin P. La maladie dite: «maladie a virus de l'oison» // Rec. Med. Vet. - 1972. - Vol. 148. - № 4. - P.455472.

175. Coudert, M., Dannacher G., Fedida M., Peillon M. Prophylaxie de la «maladie a virus de l'oison». - Rec. Med. Vet., 1973. - Vol. 149. - № 2, - P.197-208.

176. Coudert, M. Symptomes et lesions de la maladie a virus de l'oison // S'aviculture. - Rec. Med. Vet. - 1973. - T.197. - № 12. - P.15-16.

177. Coudert, M., Fedida M., Dannacher G., Peillon M. La maladie a parvovirus de l'oison. La forme tardive // Rec. Med. Vet. - 1974. - T. 150. - № 10. - P.899-906.

178. Crighton, G.W. Wilkinson G.T. A disease of goslings new to Britain // Vet. Rec. - 1970. - Vol. 87. - № 2. - P.58-59.

179. Csatari, M. A libainfluenza jarvanyos elofordulasa hazankban // Magyar Allatorv. Lapja. - 1965. - T.20. - № 4. - P.148-151. 
180. Csatari, M., Nyiredy I. A libainfluenza korokzoja - hak bakteriologiai jellemzoi // Magyar Allatorv. Lapja. - 1966. - T.21. - № 4. - P.16-18.

181.Csontos, L., M-K. Csatari $M$. Etiological studies on gosling influenza. Isolation of virus // Acta Vet. Acad. Sci. Hung. - 1967a. - T.17. - № 1. - P.107-113.

182. Csontos, L., Csatari M-K.M. Experimental infections with the isolated virus // Acta Vet. Acad. Sci. Hung. - 1967b. - T.17. - № 1. - P.115-120.

183. Csontos, L., M-K. Csatari M. Labak influenzajanak kozoktani vizsgalata. 1. Virusilalas. 2. Fertozesi kiserletek az izolalt virussal // Magyar Allatorv. Lapja. 1967c. - T.22. - № 1. - P.9-14.

184. Dannacher, G., Coudert M., Fedida M., Peillon M., Fonillett X. Etiologie de la maladie a virus de l'oison // Rec. Med. Vet. - 1972. - Vol. 148. - № 12 - P.13331349.

185. Derzsy, D., Szep I., Szöke F. Vizsgalatok az un libainfluenza koroktanarol (Elozetes kozlemeny)// Magyar All. Lapja. - 1966. - T.21. - № 9. - P.388-389.

186. Derzsy, D. A viral desiease of goslings. 1. Epidemiological, clinical, pathological and aetiological studies // Acta Vet. Acad. Sci. Hung. - 1967. - T. 17. № 4. - P.443-445.

187. Derzsy, D. Napirenden: a libainfluenza // Magyar Nezogazdasan. - 1968. - Vol.23. - № 19. - P.16-17.

188. Derzsy D., Meszaros J. Az un libainfluenza egges jarvanytani kerdesei es a vedekezes lehetösegei // Magyar Allatorv. Lapja. - 1969. - № 10. - P.537-541.

189. Derzsy, D. A viral disease of goslings // Jear book of the Vet. Med. Res. Inst. Hung. Res. Inst. Hung. Ac. of Sci. (1964-1969). - 1970. - Vol. 11. - P.79-88.

190. Derzsy, D. Dren Cs., Szedo M., Szedo J., Surjan B., Iro E. Viral desease of goslings III. Isolation, properties and antigenic pattern of the virus strains // Acta Veter. Acad. Sci. Hung. - 1970. - T.20. - № 4. - P.419-428.

191. Derzsy, D. A kislibak virusos betegsogei // Barom Baromfiipar. - 1971. Hg.18. - № 11. - P.513-520.

192. Derzsy, D., Szedo M. A viziszarnyasok fertozo betegsegei elleni vedekezes immunologiai kerdesei // Magyar Allatorv. Lapja. - 1973. - T.28. - № 8. - P.423-430.

193. Derzsy, D. Aetiologie und Bexampfung der Ganseinfluenza // Refer. In Monatsch vet. med. - 1973a. - Hg. 28. - № 24. - P. 956.

194. Derzsy, D. Eine virusbedingte Erkrankung der Ganseküken // IV Intern. Kongress der W.V.P.A. (Beograd, 15-17 IX 1969). - 1969. - P.423-428.

195. Derzsy, D. Introductory Report // Goose virus work meeting (Febr. 2022). - Budapest, 1973b.

196. Derzsy, D., Kisary J., Kontrimavichus L. M., Nadtochey G.A. Presence of reoviruses in centain goose embryo isolates obtained from outbreaks of viral gosling disease and in chickens embryos // Acta Veter. Acad. Sci. Hung. - 1975. - T. 25. - № 4. - P.383-391. 
197. Doman, I. Fiatal libak ismeretlen oktanu belgyulladasa // Magyar Allatorv. Lapja. - 1970. - T.25. - № 10. - P.529-531.

198. Dulbecco, R., Vogt M. Plaque formation and isolation of pure lines with poliomyelitis viruses // J. Exp. Med. - 1954. - Vol. 99. - № 2. - P.167-182.

199. Dvorak, B., Dvorakowa D. Infekcni hepatitida housat (Derszyno choroda) - diagnostica, prevence a profylaxe // Veterinářstvi. - 1980. - T. 30. - № 8. - P.365366.

200. Fang, D. U., Wang U. K. Studies on the aetiology and specific control of goose parvovirus infection // Sci. Agricult. sinica. - 1981. - № 4. - P.1-8.

201. Fenske, G., Kühne L. Mienhart H., Wilhelm A. Virusinfektionen bei Gänsen-eine ubersicht // Monatsch. Veter. med. - 1974. - T.22. - P.860-863.

202. Fenske, G., Kühne L. Mienhart H., Wilhelm A. Eine Viruskrankheit bei Ganseküken (virushepatitis der Ganse, Ganse-hepafitis) // Monatsch. Veter. Med. - 1975. - Bd.30. - № 5. - P.192-196.

203. Gaudry, D., TatkoffJ., Charles J.M. A propos d'un nouveau virus isole cher le canard de Barbarie. // Bulletin de la Societe des sci veter. et de med. Comparee de Lyon. - 1972. - T. 74. - № 2. - P.137-143.

204. Gough, R.E., Sparckman D., Collins M.S. Isolation and Characterisation of a parvovirus from goslings // Vet. Rec. - 1981. - Vol. 108. - № 18. - P.399-400.

205. Gough, R. E., Sparckman D. Studies with a duck embryo adapted goose parvovirus vaccine // Avian Pathol. - 1982. - Vol. 11. - № 3. - P.503-510.

206. Gough, R.E. Application of the agar gel precipitin and virus neutralisati on test to the serological study of goose parvovirus // Avian Pathol. - 1984. - Vol. 3. - P.501-509.

207. Gough, R.E. Persistence of parvovirus antibody in geese that have survived Derzsy's disease // Avian Pathol. - 1987. - Vol. 16. - № 2. - P.327-330.

208. Hanh, N.V. Fiatal libak megbetegedese Vietnamban // Magyar Allatorv. Lapja. - 1974. - T.29. - № 4. - P.262-267.

209. Hansen, $H$. Derzsy's desease (pervavirus infection has gaes) // Dansk Erhversfjerkrt. - 1979. - Vol. 8. - P.423-425.

210. Hansen, H.Ch. Derzsy's disease (Parvovirusinfection has gaes) // Dan. Veterinaertiedsskr. - 1980. - Bd.63. - № 5. - P.191-194.

211. Hauswirth, W.W. Autonomous parvovirus DNA structure and replication // Parvoviruses. - N. Y.; London, 1984. - P.129-152.

212. Have, P., Hansen H.C. Detection of goose Parvovirus antibodies by microneutralisation and enzyme-linked immunosorbent assay // Proc. 7th World. Vet. Poult. Assoc. - 1981. - P.60.

213. Hoekstra, J., Smit T. H., Corrie van Brakel. Observations on host range and control of goose virus hepatitis // Av. Pathology. - 1973. - Vol. 2. - № 3. - P.169-178. 
214. Hoekstra, J., Yadin W.A. Gänsen virus hepatitis Vortrag // 5. Internat. Kongr. Welt-Geflügel-Vereinigung. Munchen. - 1973. - № 2.

215. Johnson, F.B. Parvovirus proteins // Parvoviruses. - N.Y.; London, 1984. P.259-295.

216. Kaleta, E.F. Celo-virus bei Ganseküken // Dtsch. Tierarztl., Wschz. - 1969. - № 16. - P.427.

217. Kardi, V., Szegletes $E$. Use of ELISA procedures for the detection of Derzsy's disease virus of geese and of antibodies produced against it // Avian Pathologie. 1996. - № 25. - P.25-34.

218. Kisary, J. Some growth characteristics of goose parvovirus stain «B» // Acta Vet. Acad. Sci. Hung. - 1974. - T.24 - F.3. - P.329-333.

219. Kisary, J., Derzsy D. Viral disease of goslings. IV. Characterization of the causal agent in tissue culture system // Acta Vet. Acad. Sci. Hung. - 1974. - T.24. - № 3. - P.287-292.

220. Kisary, J. Gross - neutralization tests on parvaviruses isolated from goslings // Av. Pathology. - 1974. - Vol.3. - № 4. - P.293-296.

221.Kisary, J., Derzsy D., Demokos. Az un libainfluenza korokotana a korokotana, korokozo rendszertani besorolasa // Magyar Allatorv. Lapja. - 1975. T. 30. - № 3. - P.199-201.

222. Kisary, J., Derzsy D., Horvath E. Az un libainfluenza elleni szikimmunitas jarvanytani je lentosege // Magyar Allatorv. Lapja. - 1975b. - T.30. - № 10. - P.721723.

223. Kisary, J. Buoyant density of goose parvovirus strain «B» // Acta microbiol. Acad. Sci. Hung. - 1976. - Vol.23. - № 2. - P.205-207.

224. Kisary, J., Meszaros J. Aktiv immunizalasi kiserletek a kisliban Derzsy-fele befegsege (un libainfluenza) ellen.2. Laboratoriumi es nagyuzemi vedesi kiserletek // Magyar Allatorv. Lapja. - 1977a. - T.32. - № 12. - P.788-792.

225. Kisary, J. Immunnological aspects of Derzsy's, diseases in goslings // Avian pathol. - 1977. - Vol. 6. - № 4. - P.327-334.

226. Kisary, J., Maszaros J. A szerumkezeles idejenek hatasa a Derzsy - fele betegseg (un libainfluenza) ellen vedelem hatekonysagara // Magyar All. Lapja. 1977b. - T.32. - № 12. - P.795-797.

227. Kisary, J., Derzsy D., Kontrimavichus L.M., Bezsilla E. Aktiv immunizalasi kiserletek a kisliban Derzsy- fele befegsege (un libainfluenza) ellen. 1. Csokkent viry lenciajn virustorzs vizgalata // Magyar Allatorv. Lapja. - 1977. - T.32. - № 12. P.785-787.

228. Kisary, J., Zsak L. Comparative studies on duck viral enteritis (DVE) virus strains in geese // Av. Pathol. - 1983. - Vol. 12. - № 4. - P.395-408. 
229. Kisary, J., Nagy B, Bitay Z. Presense of parvovirus in the intestine of chickens showing stunting syndrome // Av. Pathol. - 1984. - Vol. 13. - № 2. P.339-343.

230. Kisary, J. Indirect Immunofluorescence as a diagnostic tool for parvovirus infection of chickens // Avian Pathology. - 1985. - № 14. - P.269.

231. Kokles, R., Kinpel A., Reckling K.H. Zur Parvovirusinfection der Gunggänse (Derzy'she Krankheit) (Kurzmitteilung) // Mh. Vet. Med. - 1985. - P.707-708.

232. Krauss, $H$. Eine verlustreiche Aufzuchtkrankheit bei Ganseküken (Erste Mitteilung) // Berl. und Munch. Tierarztl. Wochenschrift. - 1965. - Jg.78. - № 19. - P.372-375.

233. Krauss, H.Aviare REO - Viren // Berl. und Munch. tierarztl. Wschr- 1967Jg.80. - № 23. - P.458-461.

234. Krauss, $H$. Inapparente virusinfektionen beim geflugel und ihre Bedeutung unter berucksichtigung eines erstmals isolierten agens // Zbl. Veter. Med. - 1968. - B.15. - № 3. - P.317-352.

235. Kwang, M.J., Tsai H.J., Lu Y.S., Fei A. C. Y., Lee Y. L., Lin D. F. and Lee C. Detection of antibodies against goose parvovirus by an enzyme-linked immunosorbent assay (ELISA) // J. Chin. Soc. Vet. Sci. - 1987. - Vol.13. - № 1. - P.1723.

236. Kwang, M.J., Tsai H.J., Lu Y.S., Fei A. C. Y., Lee Y. L., Lin D. F. and Lee C. Detection of antibodies against goose parvovirus by an enzyme-linked immunosorbent assay (ELISA) // Vet. Bull. - 1988.- Vol.58. - № 5. - P.334.

237. Labie, Ch. Hepato-nephrite-ascite (HNA) des Oisons histopathologie et histoimmunofluorescence // Ann. Rech. Veter. - 1972. - Vol. 3. - № 3. - P. 483-492.

238. Liao, Y.K., Lu Y.S. Detection of Derzsy's disease viral antigen by ELISA and latex agglutination // Proceedings of the 5th Asian-Australasian Association of Animal Production Societies Congress, Taipei, ROC on Taiwan. - 1990.-Vol. 3. P.208.

239. Majaniemi, I., Sieg/ G. Early events in the replication of parvovirus Lu3 // Arch. Virol. - 1984. - Vol. 8. - № 3/4. - P.285-302.

240. Mandelli, G., Rinaldi A., Cessi D., Cervio G., Lodetti E., Valeri A. Aspetti ultrastructurali della cosiddetta "Influenza» (Miocardite infettiva) dell oca // Affi della Soc. Italiana delle Sci. Veter. - 1970. - XXIV. - P.654-656.

241. Mandelli, G., Valeri A., Rinaldi A., Lodetti E. Reperti istlogici ed ultramicroscopidi una malattia virale delle giovnioche. - Folia veter. Latina. - 1971. - Vol.I. - P.121-170.

242. Marius, V., Bonnaud P., Gultet M. Resultats d'une enquete serologique effectuce en France (Vendce) chez canard a rotiz // Av. Pathol- 1983- Vol. 12. - № 4. - P.412-435. 
243. Matthews, R.E.F. Classification and nomenclature of viruses // Intervirology. - 1982. - Vol.17. - № 1/3. - P.72-75.

244. Mendelewska, J., Mendelewska F. Proba analizy upadkow gesi w chowie intensywnym // Med. Weter. - 1980. - T.36. - № 1. - P.42-45.

245. Molitor, T.W., Joo H.S., Collet M.S. Porcine parvovirus: virus purification and structural and antigenic properties of virion polypeptides // J. Virol. - 1983. Vol. 45. - № 2. - P.842-854.

246. Müller, D. E., Siegl G. Maturation of parvovirus Lu3 in a subcellular system.I. Optimal conditions for in vitro synthesis and encapsidation of viral DNA // J. Gen. Virol. - 1983. - Vol. 64. - № 5. - P.1043-1054.

247. Nagy, Z., Derzsy D. A viral disease of goslings. 2. Microscopic lesions // Acta Veter. Acad. Sci. Hung. - 1968. - T.18. - № 1. - P.3-18.

248. Peter, W. Virologische Arbeiten zur Gäncehepatitis // Monatsh. Veterinärmed. - 1982. - № 22. - P.847-849.

249. Peter, W. Parvovirusinfection bei Gänsen // Mh. Vet.-Med. - 1985. - Jg.40. - № 19. - P.63-68.

250. Poonia, B., Dunn P.A., Lu H., Jarosinski K.W., Schat K.A. Isolation and molecular characterization of a new Moscovy duck parvovirus from Moscovy ducks in the USA // Avian Pathology. - 2006. - V. 35. - № 6. - P.435-441.

251. Rinaldi, A., Mandelli G.C., Cessi D., Cervio G., Lodetti E., Valeri A. Identificazione di un focolaio di cosiddetta «influenza dell'oca» in Italia // Selezione Vet. - 1970. - P.11, 25, 250-252.

252. Roszkowski, J., Gardzinski P., Kozaczynski W., Bartoszoze M. Application of the immunoperoxidase technique for the detection of Derzsy's desease virus antigen in cell culture and goslings // Avian Pathol. - 1982. - Vol. 11. - № 4. - P.571578.

253. Samberg, G. A new infections disease of goslings in Israel / // Refuah Veterinarith. - 1972. - Vol.29. - № 1. - P.29-33.

254. Samberg, G., Bock R., Perlstein Z. Virushepatitis bei Gansen. I. Mittellung:Untersuchungen zur Klarung der Atiologie / Schettler C.H. // Tierarztl. Umsahau. - 1971a. - Jg.26. - № 2. - P.60-66.

255. Schettler, C.H. Virus hepatitis of Geese II. Host Range of goose hepatitis virus // Avian Dis. - 1971b .- Vol.15. - № 4. - P.809-823.

256. Schettler, C.H. Gänsezucht wird wieder sttraktiv // Dt. Geflügelwirsch. 1971c. - Jg.23. - № 3. - P.55-74.

257. Schettler, C.H. Goose virus hepatitis in the Canada goose and snow goose // J. Wildlife Desease. - 1971d. - Vol. 7. - № 3. - P.147-148.

258. Schettler, C.H. Isolation of a highly pathogenic virus from geese wiht hepatitis // Avian Dis. - 1971e. - Vol. 15. - № 2. - P.323-325. 
259. Schettler, C.H. Nachweis der vertikalen ubertragung des virus der Ganschepatitis // Dt. Tierarztl. wschr. - 1972. - Hg.79. - № 8. - P.202-203.

260. Schettler, C.H. Virus hepatitis of Geese III. Propertis of the cause agent // Av. Pathol. - 1973. - Vol. 2. - P.179-193.

261. Siegl, G. Biology and pathogeneticity of autonomous parvoviruses // Parvoviruses. - N.Y.; London. - 1984a. - P.297-362.

262. Siegl, G. The human parvovirus // Parvoviruses. - N.Y.; London. - 1984b. - P.389-395.

263. Siegl, G., Bates R.C., Berns K. I. Characteristics and taxonomy of Parvoviridae // Intervirology. - 1985. - Vol.23. - № 2. - P.61-73.

264. Šnoflák, J., Vachová H. Vakcina proti chorobi // Veterinářstvi. - 1982. Vol. 32. - № 1. - P.33-35.

265. Srivastava, A., Lusby E.W., Berns K.I. Nucleotide sequence and organization of the adenoassociated virus 2 genome // J. Virol. - 1983. - Vol. 45. - № 2. - P.555564.

266. Süveges, T., Szencsenyi I. Kislobak tömeges elhullasanak koroktani vizsagalata // Magyar Allatorv. Lapja. - 1970. - T.20. - № 10. - P.541-545.

267. Szalai, F., Bernath S. Vizsgalatok libapipek között 1969 - ben jelentkezett megbetegedes koroktananak. tisztazasara. 2. Specifikus vedekezö eljaras (passziv immunizalas) kidolgozasa Hiperimmun szerum termelese. 3. Korszovettani vizsgalatok // Magyar Allatorv. Lapja. - 1971. - T.26. - № 8. - P.420-423.

268. Szedö, M. Laboratory ad practical serotherapeutie experiments against the so called goose influeza with special reference to be the antigenic variante // Report delivered at the Internat. Symposium Geese. - Budapest, 1971.

269. Szencsenyi, I. Adatok az «un libainfluenza» jarvanytanahoz, es a vedekezes lehetosege // Magyar Allatorv. Lapja. - 1967. - T.22. - № 11. - P.516-524.

270. Szenczenyi, I. Attempts to create breeding flocks of geese free from «influenza» // Magyar Allatorv. Lapja. - 1971. - T.26. - № 11. - P.637-640.

271. Tattersall, P., Ward D. The parvoviruses - an introduction // Replication of mammalian parvoviruses, Cold Spring Harbor. - 1978. - P.3-12.

272. Temesi, Z. Kiserletek a libainfluenza koroktanaval kapesolatban // Magyar Allatorv. Lapja. - 1966. - T.21. - № 9. - P.385-388.

273. Trefilov, B., Nikitina N., Mikhailov A., Yavdoshak L., Dmitrieva. An inactivated emulsified vaccine against a parvoviral infection of geese // XVIII Congress World Veterinary Poultry Associatio French branch (GF-AMVA), $19-23$ august 2013. - Nantes France, 2013. - P.571.

274. Vuillaume, A., Tournut J., Banon H. A propos de la maladie des oisons d'apparition tardive on nephrite hemorragigue - enterite de l'oie (N.H.E.O.) // Rev. Med. Vet. - 1982. - T.133. - № 5. - P.341-346. 
275. Wong, F.C., Sperman J. G., Smolenski M. A. Equine parvovirus: unitial isolation and partial characterization // Can. J. Comp. Med. - 1985. - Vol. 49. №1. - P. 50-53.

276. Woodruff, A. M., Goodpasture E. M. The susceptibility of the chorioallantoic membrane of chick embryo to infection with the fowl pox virus // Amer. J. Path. - 1931. - V.7. - P.209.

277. Wyeth, P.J., Chette N.J. Comparison of the efficacy of four inactivated infections bursal disease oil emulsion vaccines // Vet. Rec. - 1982. - Vol. 110. P.359-361.

278. Younger, J.S. Monolayer tissue cultures: preparation and standardization of suspensions of trypsin-dispersed monkey kidney cells // Prac. Soc. Exp. Biol. and Med.-N.Y., 1954. - Vol. 85. - № 2. - P.202-209.

279. Zalay, J. Az «un libainfluenza» elofordulasa Bekes medyci termeloszovetkzetek libaallomnyaban // Magyar Allatorv. Lapja. - 1967. - T.22. - № 11. - P.525-528.

280. Ziedler, K., Marx G., Heidrich R., Sobanski E. Zum auttreten einer

virusbedingten Ekrankung bei Moschusenten // Mh. Vet.-Med. - 1978. - Jg.33. - № 45. 


\section{ОГЛАВЛЕНИЕ}

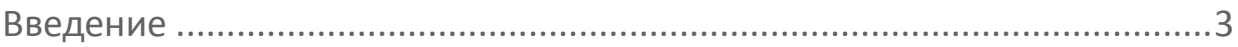

Значение и предпосылки инновационного развития

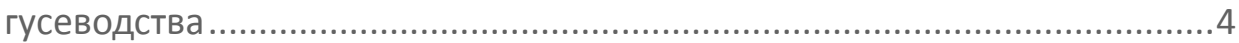

Глава 1. Характеристика семейства парвовирусов................................. 7

Глава 2. Парвовирус гусей и его биологические свойства (генетические признаки).

2.1. Этиологические факторы ....................................................12

2.2. Морфология вирусной частицы ..........................................13

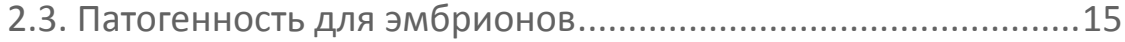

2.4. Патогенность для птиц .......................................................17

2.5. Устойчивость парвовируса к физико-химическим

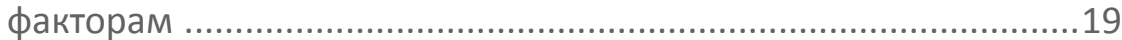

2.6. Антигенная специфичность и степень нейтрализации специфической антисывороткой .............................................21

2.7. Способность к репродукции в различных

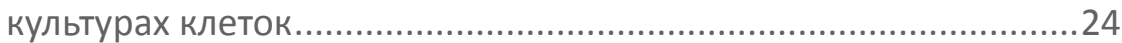

Глава 3. Парвовирусная инфекция гусей................................................28

3.1. Хронологическая справка, распростарнение и ущерб, причиняемый этой болезнью..................................................28

3.2. Эпизоотологические данные болезни.................................30

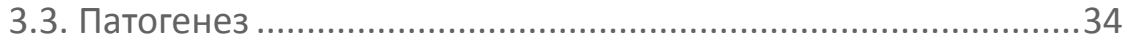

3.4. Клинико-патоморфологические признаки............................35

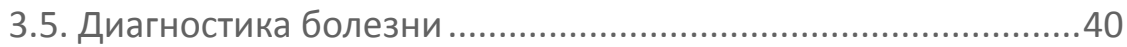

3.6. Профилактика и меры борьбы............................................42

Глава 4. Разработка средств специфической профилактики

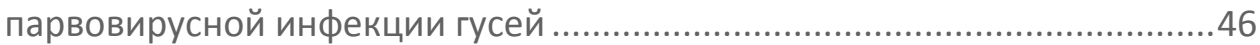

4.1. Селекция вакцинного клона парвовируса гусей....................46

4.2. Отработка оптимального режима

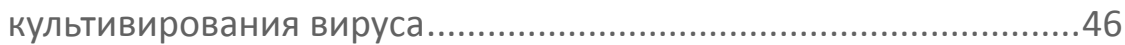

4.3. Сроки наступления и продолжительность иммунитета.........47

4.4. Разработка технологии изготовления и методов контроля вирусвакцины ВНИВИП сухой культуральной против вирусного энтерита гусей ............................................49

4.5. Разработка инактивированной вакцины против парвовирусной инфекции гусей .................................................49

4.6. Стратегия профилактики болезни........................................53

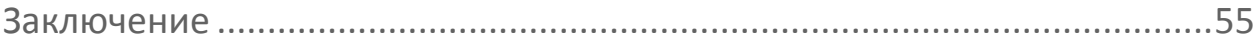

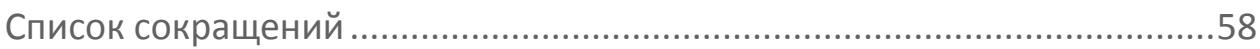

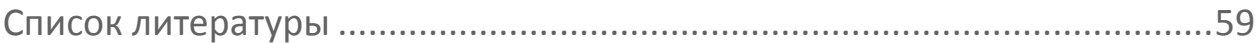




\section{ПАРВОВИРУСНАЯ ИНФЕКЦИЯ ГУСЕЙ}

Авторы: Трефилов Б.Б., Никитина Н.В., Явдошак Л.И. Дизайн-верстка: Г.В. Зайцева

Подписано в печать с оригинал-макета 24.10.2013.

Формат 165×233. Печать цифровая.

Бумага офсетная. Усл. печ. л. 10,64.

Тираж 100. Заказ № 5258.

Отпечатано в типографии «Любавич».

ООО «Первый издательско-полиграфический холдинг», Санкт-Петербург, Б. Сампсониевский пр., 60, лит. «У». Тел.: (812) 6032525. 


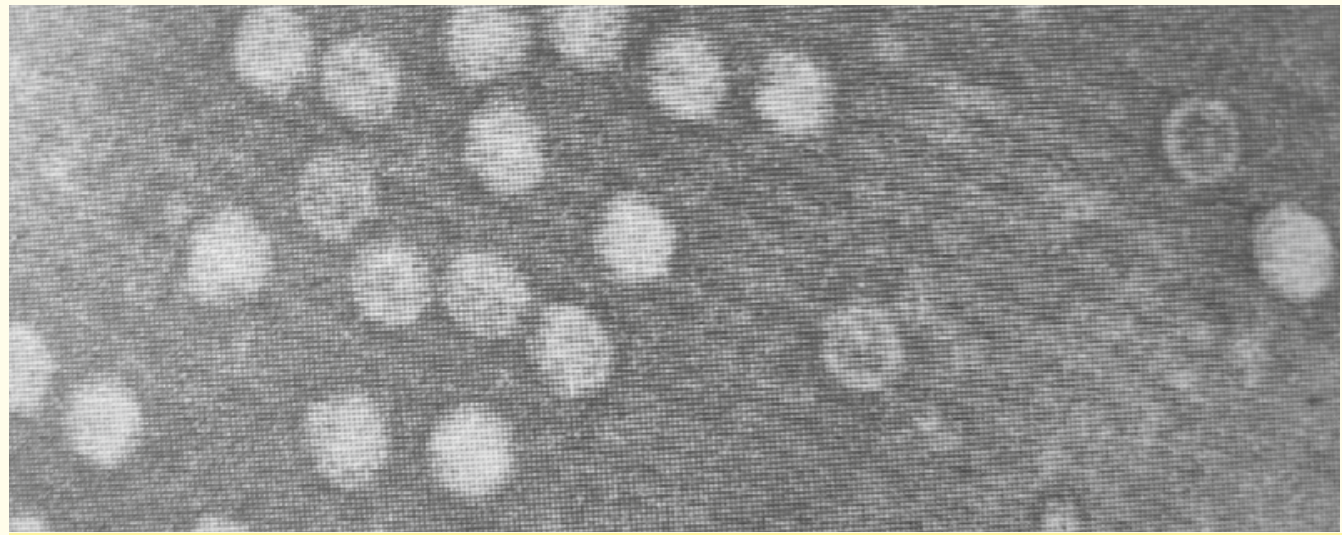

Рис. 1. Парвовирус крупного рогатого скота, Н-1. Увел. х 171000.

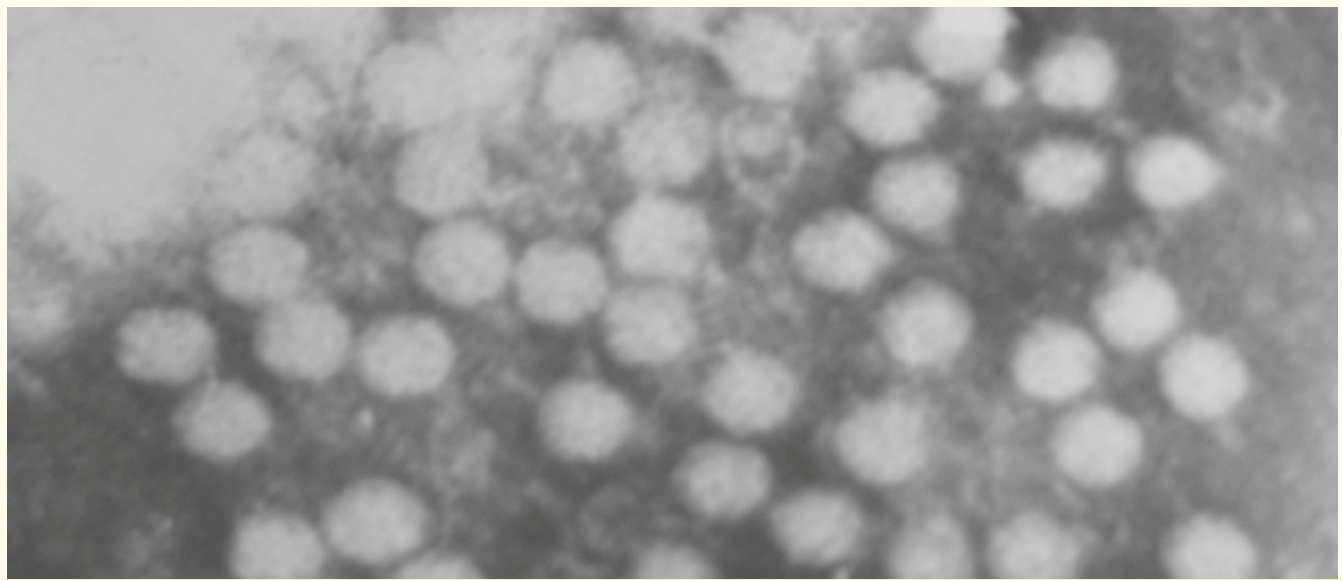

Рис.2. Парвовирус гусей, клон 6 итамма «П-75». Увел. х 315000.

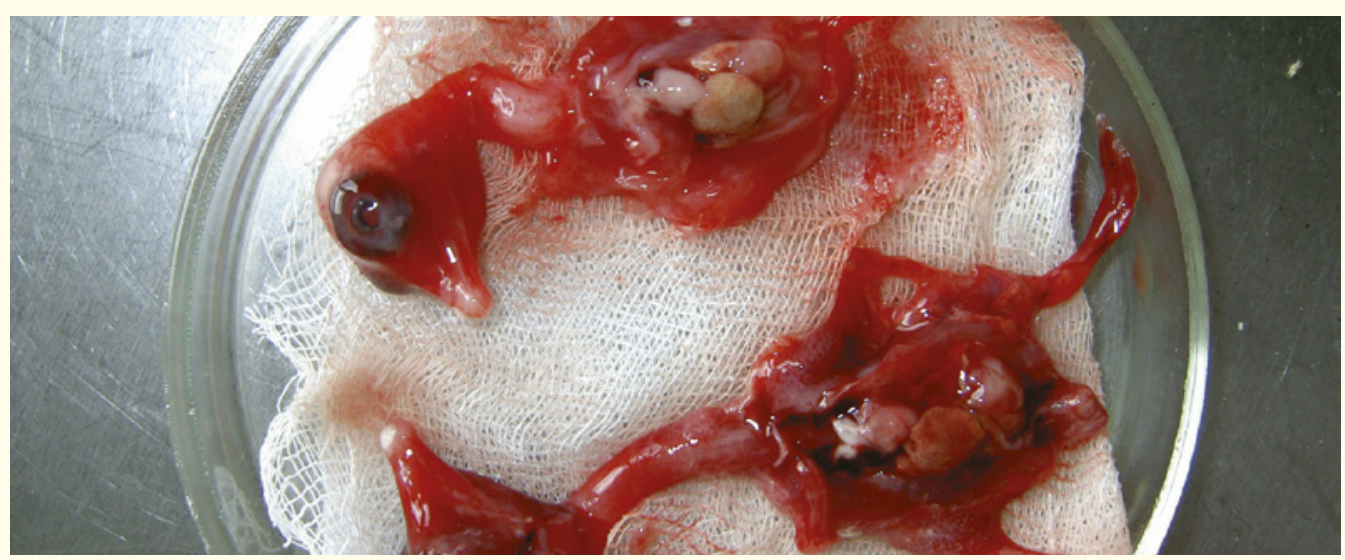

Рис. 3. Гусиный эмбрион, зараженный эпизоотическим итаммом 


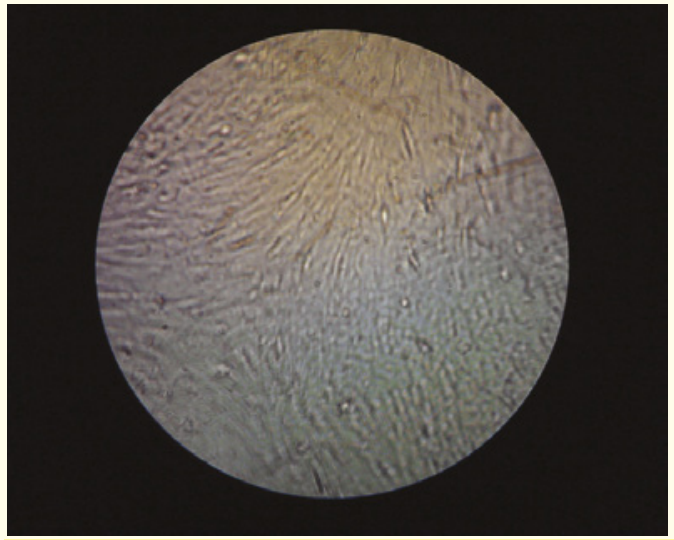

а) незараженная культура

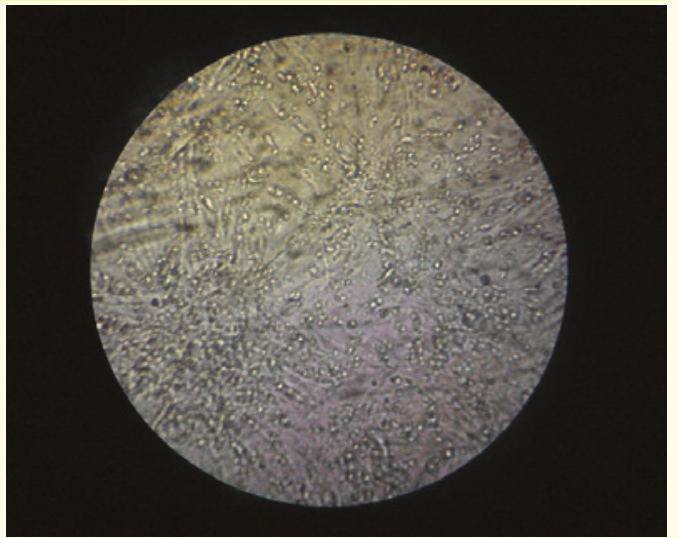

б) зараженная культура клеток «клоном 6» штамма «П-75» парвовируса гусей через 72 часа.

Рис.4. Культура клеток гусиных эмбрионов

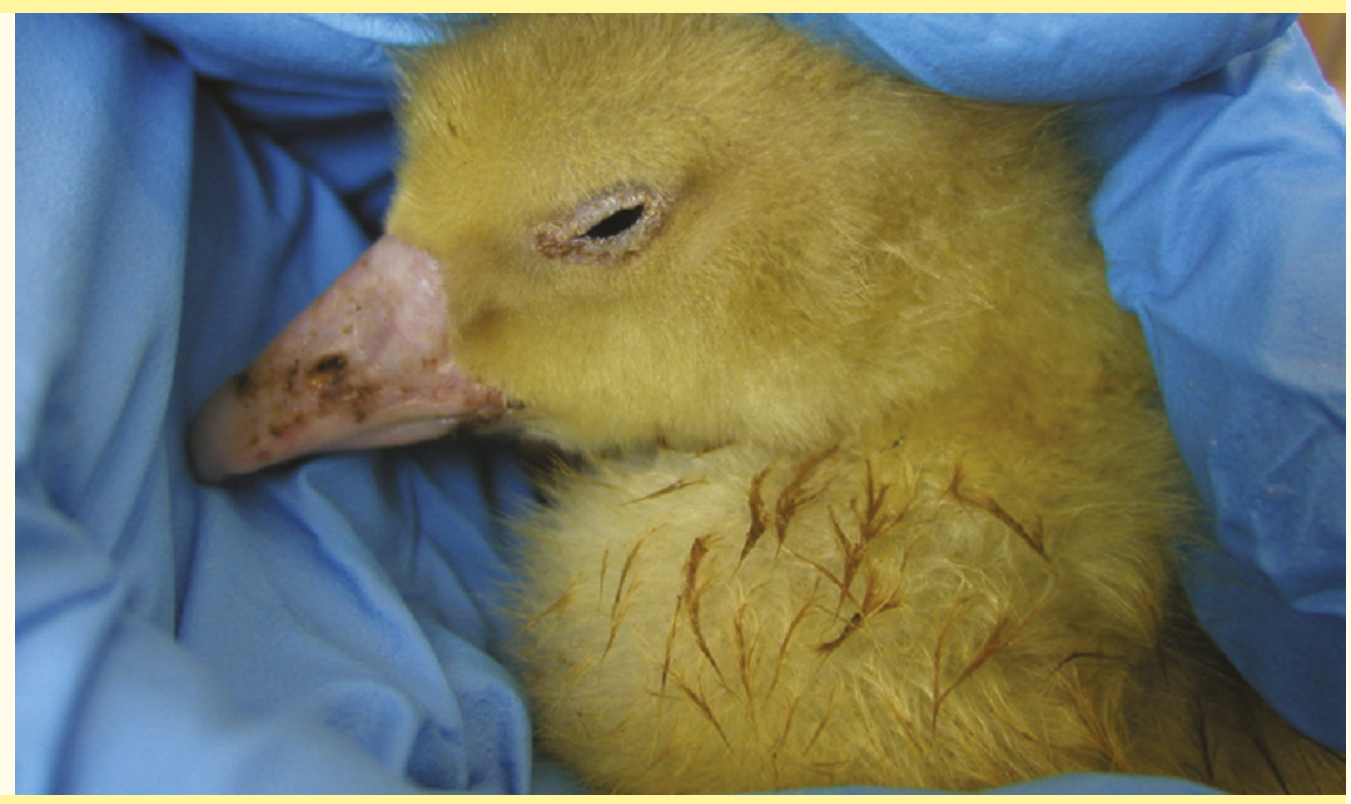

Рис. 5. Больной гусенок

(сужение глазной щели, конъюнктивит, истечение из носа). 


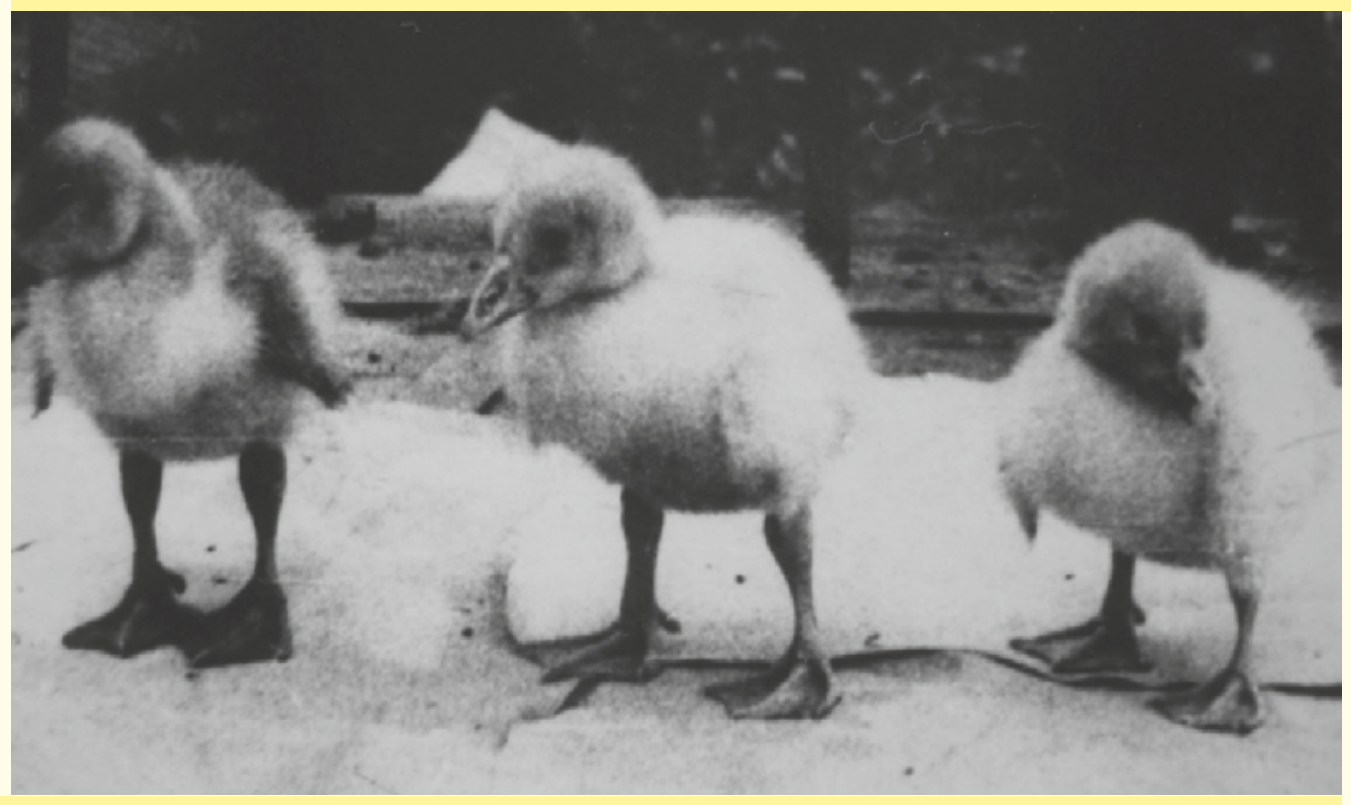

Рис.6. Больные парвовирусной инфекцией 16-суточные гусята.

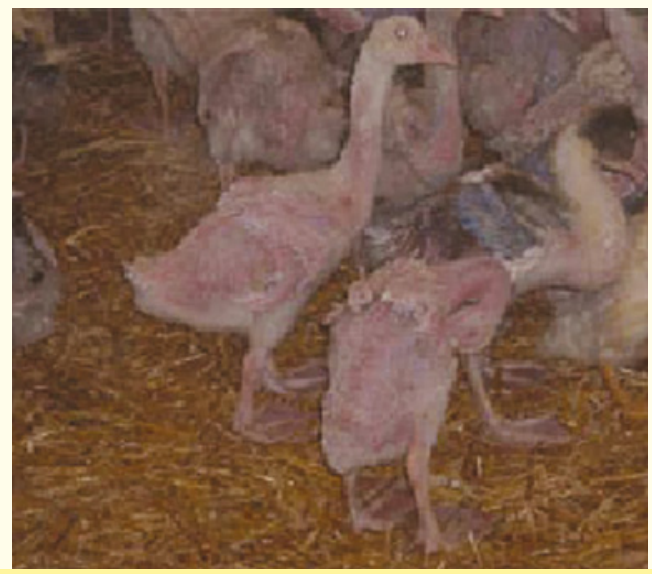

а) плохое оперение, выщипывание пуха и перьев;

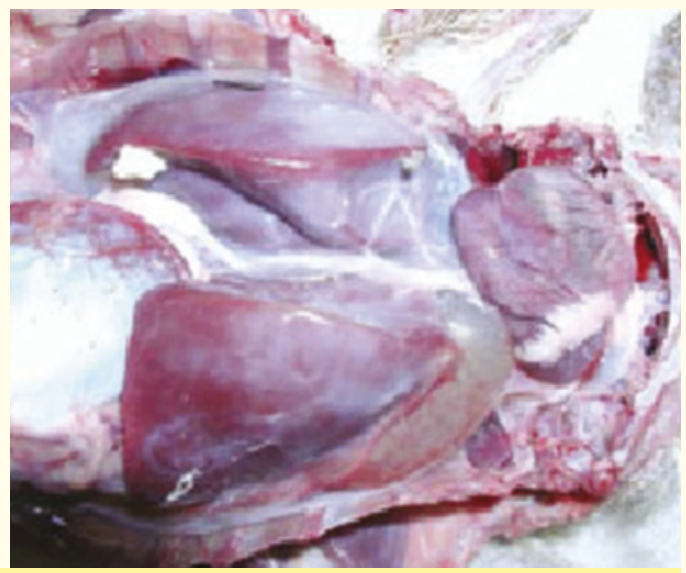

б) серозно-фрибринозный перигепатит и асцит

Рис.7. Хроническое течение вирусного энтерита гусей 


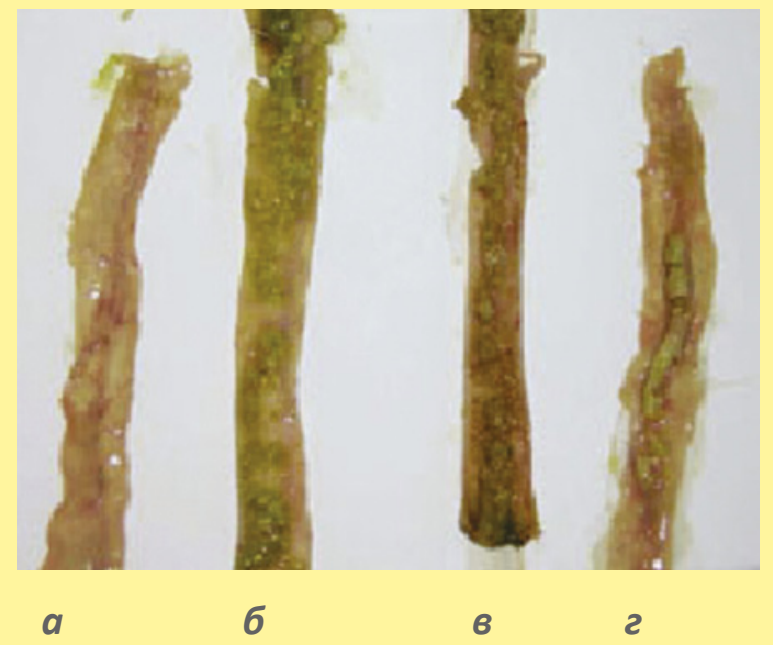

Рис.8. Геморрагический (а), катаральный (б), некротический (в), фибринозный (2) энтерит.

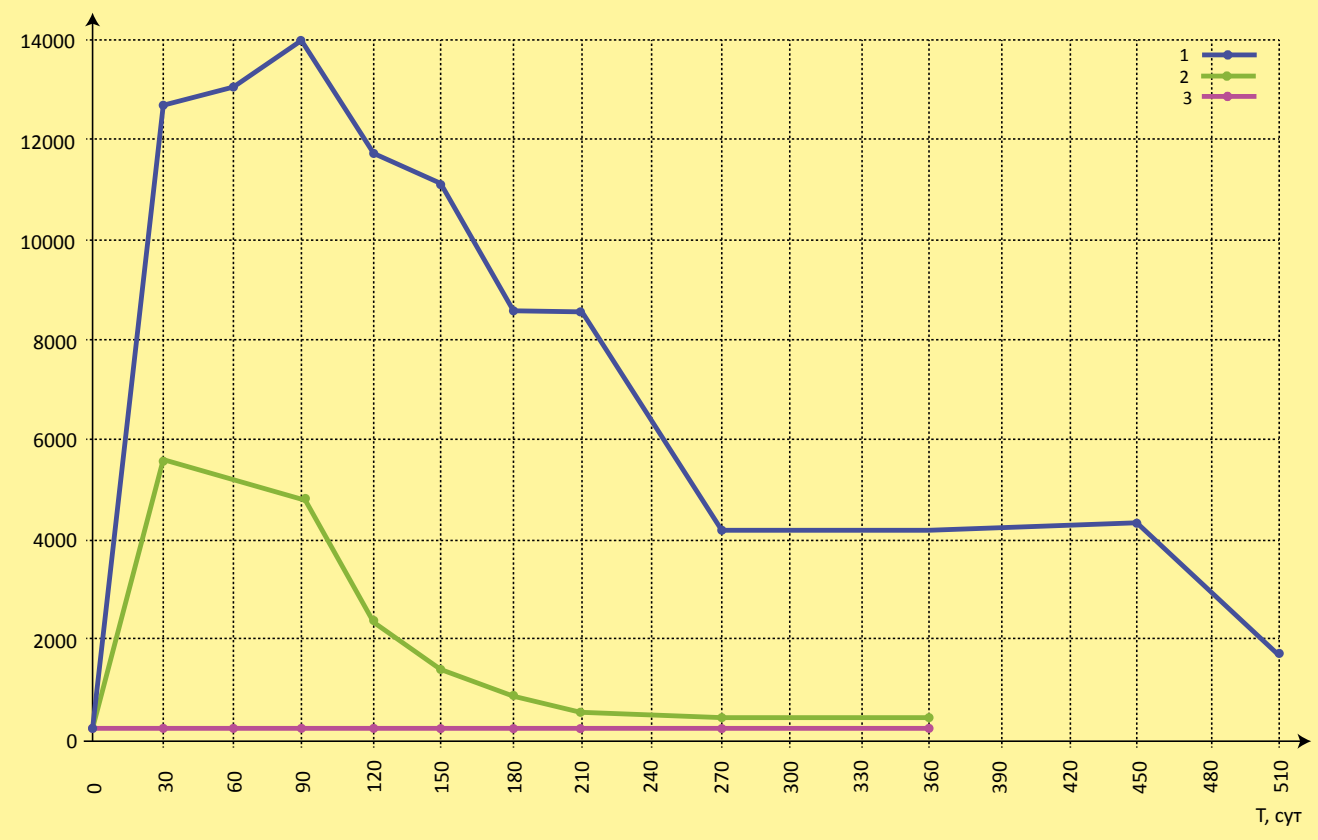

Рис.9. Динамика выработки специфических антител у вакцинированных против парвовирусной инфекции гусей:

1 - гуси, иммунизированные инактивированной эмульгированной вакциной; 2 - гуси, иммунизированные вирусвакциной вНИВИП;

3-гуси невакцинированные. 
РОССИЙСКАЯ АКАДЕМИЯ СЕЛЬСКОХОЗЯЙСТВЕННЫХ НАУК

ГОСУДАРСТВЕННОЕ НАУЧНОЕ УЧРЕЖДЕНИЕ

ВСЕРОССИЙСКИЙ НАУЧНО-ИССЛЕДОВАТЕЛЬСКИЙ

ВНИВИП разрабатывает, изготавливает и реализует ветеринарные препараты и диагностические наборы для профилактики и диагностики инфекционных болезней птиц

\section{Вакцины ВНИВИП - гарант эпизоотического} благополучия и высокой рентабельности птицехозяйств
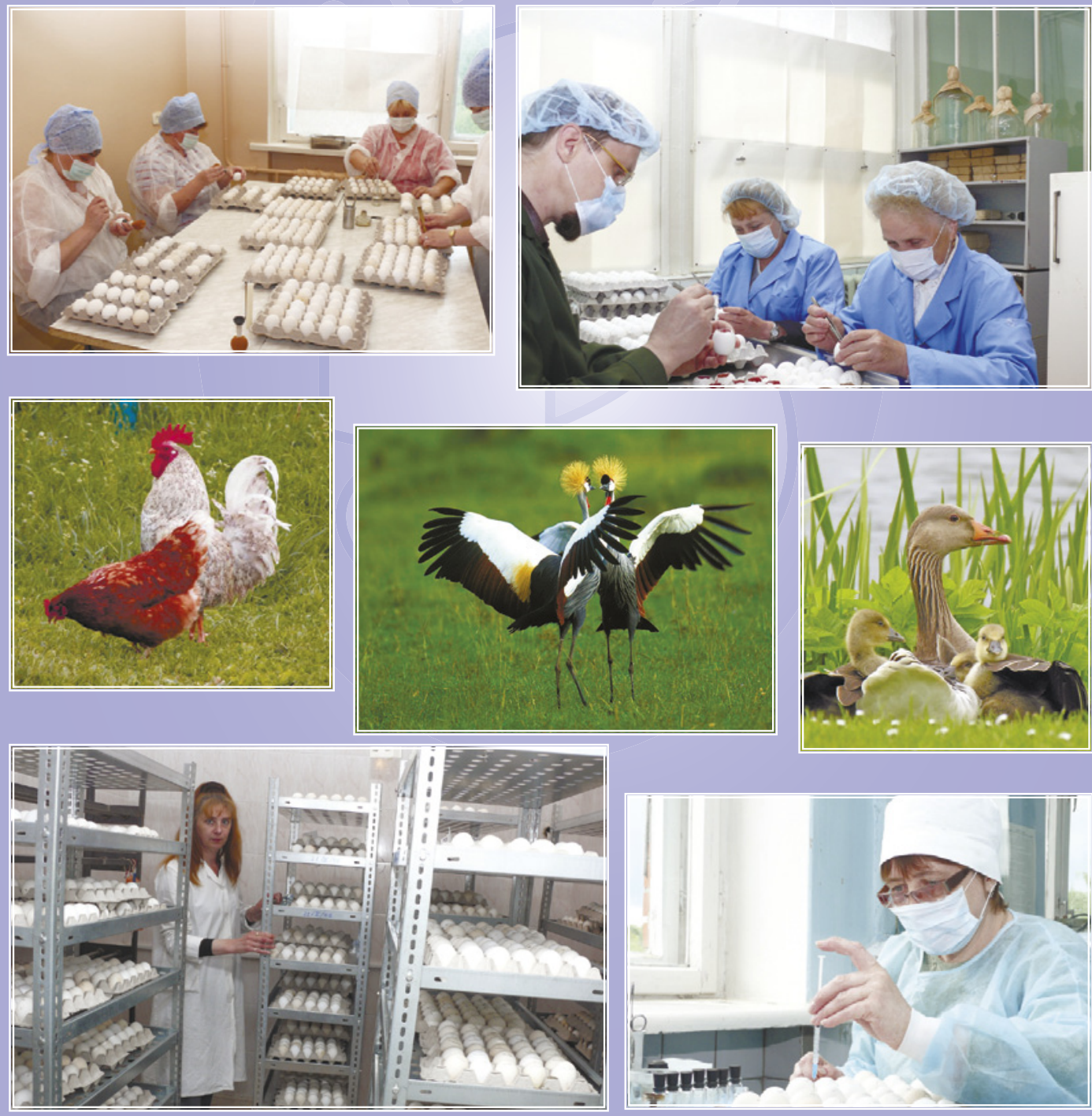
РОССИЙСКАЯ АКАДЕМИЯ СЕЛЬСКОХОЗЯЙСТВЕННЫХ НАУК

ГОСУДАРСТВЕННОЕ НАУЧНОЕ УЧРЕЖДЕНИЕ

ВСЕРОССИЙСКИЙ НАУЧНО-ИССЛЕДОВАТЕЛЬСКИЙ

ВЕТЕРИНАРНЫЙ ИНСТИТУТ ПТИЦЕВОДСТВА

198412,г.Санкт-Петербург,Ломоносов,ул. Черникова, д.48

T/\$ 8 (812) 372-54-80, 372-54-81, e. mail: vnivip@yandex.ru, www.vnivip.com

\section{ВАКЦИНА ПРОТИВ ВЫСОКОПАТОГЕННОГО ГРИППА ПТИЦ (ВПГП) ПОДТИПОВ Н5 И Н7 ИНАКТИВИРОВАННАЯ}

В зависимости от эпизоотической ситуации и потребности заказчика вакцина может применяться как в моновалентной форме и включать в себя антиген подтипа Н5 или H7, так и в бивалентной форме.

Препарат разработан с учетом стратегии «DIVA» (Differentiating Infected from Vaccinated Animals), что обеспечивает следующие преимущества:

- возможность проводить дифференциацию инфицированной птицы от вакцинированной, благодаря гетерологичности нейраминидазы; - безопасное производство, при котором не используются высоковирулентные штаммы вируса гриппа.

Препарат разработан и может применяться для вакцинации птицы любого возраста,в том числе цыплят с первых часов жизни и обладает :

- иммуногенностью независимо от уровня родительских антител;

- совместимостью с живыми и инактивированными вакцинами, применяемыми в птицеводстве;

- способностью формировать длительный иммунитет при однократном введении.

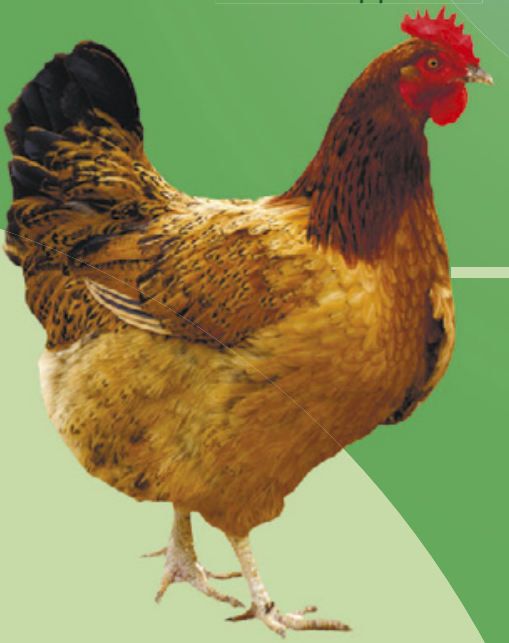

Вакцины ВНИВИП гарант эпизоотического

благополучия и высокой рентабельности птицехозяйств! 
198412,г.Санкт-Петербург,Ломоносов,ул.Черникова, д.48 т/\$ 8 (812) 372-54-80, 372-54-81, e. mail: vnivip@yandex.ru, www.vnivip.com

\section{ВАКЦИНА \\ ПРОТИВ МЕТАПНЕВМОВИРУСНОЙ ИНФЕКЦИИ ПТИЦ ЖИВАЯ СУХАЯ}

Вакцина предназначена для профилактики метапневмовирусной инфекции птиц в племенных и товарных хозяйствах различного направления выращивания.

По внешнему виду вакцина представляет собой пористую массу однородной структуры от бледно-розового до темно-бежевого цвета, легко растворимую в воде без образования хлопьев и осадка.

Вакциной прививают цыплят с суточного возраста, двукратно интраназальным методом (окулярно) или методом крупнокапельного распыления (спрейметод).

Иммунный ответ формируется через 14 суток после двукратного применения и сохраняется в течение 2 месяцев.

Преимущества вакцины:

Основным преимуществом разработанной вакцины является то, что она может быть изготовлена на основе серотипов А или В, циркулирующих на территории РФ, что обеспечивает полную защиту от полевого вируса.

Вакцина обладает высокой безопасностью и ареактогенностью ;

- способствует повышению сохранности до 95-98 \%;

- повышает рентабельность работы предприятия:

- не вызывает поствакцинальных реакций;

Вакцины ГНУ ВНИВИП - гарант эпизоотического благополучия и высокой рентабельности птицехозяйств !

Наш опыт и компетентность - Ваш успех! 


\section{(6) \\ РОССИЙСКАЯ АКАДЕМИЯ СЕЛЬСКОХОЗЯЙСТВЕННЫХ НАУК ГОСУДАРСТВЕННОЕ НАУЧНОЕ УЧРЕЖДЕНИЕ ВСЕРОССИЙСКИЙ НАУЧНО-ИССЛЕДОВАТЕЛЬСКИЙ ВЕТЕРИНАРНЫЙ ИНСТИТУТ ПТИЦЕВОДСТВА}

198412,г.Санкт-Петербург,Ломоносов,ул.Черникова, д.48 T/\$ 8 (812) 372-54-80, 372-54-81, e. mail: vnivip@yandex.ru, www.vnivip.com

\section{ВНИВИП предлагает свою новую разработку- отечественную многокомпонентную вакцину «АВИКОКС» \\ «АВИКОКС»-ВАКЦИНА АЛЯ ПРОФИЛАКТИКИ КОКцИДИОзОВ КУР}

Вакцина "АВИКОКС» - предназначена для иммунопрофилактики икокцидиоза кур.

Вакцина применяется однократно, с 3-х суточного возраста цыплят бройлеров, ремонтного молод,няка и кур-несушек, с кормом или выпаиванием.

По требованию заказчика вакцина комплектуется слабовирулентными штаммами эймерий - E.acervulina, E.maxima, E.necatrix и E.tenella - в различных комбинациях- от одного до четырех видов в одной иммунизирующей дозе.

Преимущества вакцины:

- не требует применения кокцидиостатиков;

- безвредна даже при пятикратной передозировке;

- формирует антикокцидийный иммунитет у всего поголовья одновременно;

- обеспечивает получение экологически чистой продукции в отношении кокцидиостатиков и их метаболитов;

- уменьшает затраты на профилактику кокцидиоза в 3-5 раз.

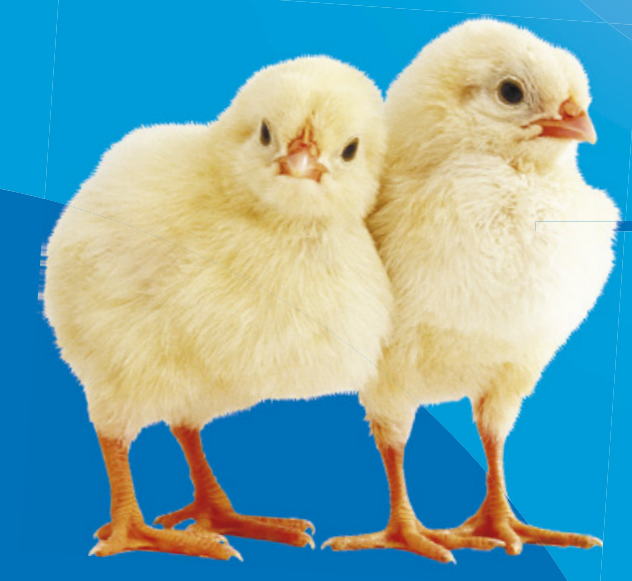

Вакцинация способствует обновлению кокцидиофауны хозяйства и восстановлению эффективности кокцидиостатиков 
РОССИЙСКАЯ АКАДЕМИЯ СЕЛЬСКОХОЗЯЙСТВЕННЫХ НАУК

ГОСУДАРСТВЕННОЕ НАУЧНОЕ УЧРЕЖДЕНИЕ

ВСЕРОССИЙСКИЙ НАУЧНО-ИССЛЕДОВАТЕЛЬСКИЙ

ВЕТЕРИНАРНЫЙ ИНСТИТУТ ПТИЦЕВОДСТВА

\section{2,г.Санкт-Петербург,Ломоносов,ул.Черникова, д.48 т/ф 8 (812) 372-54-80, 372-54-81, e. mail: vnivip@yandex.ru, www.vnivip.com}

\section{ВИРУСВАКЦИНА СУХАЯ \\ ПРОТИВ ЛАРИНГОТРАХЕИТА ПТИЦ ИЗ ШТАММА "ВНИИБП"}

Вакцина предназначена для специфической профилактики инфекционного ларинготрахеита птиц. Успешно применяется в условиях промышленного птицеводства РФ и стран СНГ с 1988 года. Вакцина профилактирует болезнь на 95-100\%, лишена конструктивных недостатков живых вакцин, применяемых в птицеводстве.

Вакцина применяется для иммунизации птицы с 30-суточного возраста энтерально, окулярно, клоачно, аэрозольно. Иммунитет формируется на 12-14-е сутки после вакцинации, сохраняется в течение 6 месяцев.

Преимущества вакцины:

- обладает высокой антигенностью и иммуногенностью;

- генетически стабильна;

- не обладает реверсибельностью в процессе эксплуатации;

- не вызывает поствакцинальных осложнений;

- способствует выращиванию здорового молодняка с высокими показателями сохранности и продуктивности;

- обеспечивает эпизоотическое благополучие птицехозяйства по инфекционному ларинготрахеиту;

- повышает рентабельность производства;

\section{Вакцины ГНУ ВНИВИП - гарант} эпизоотического благополучия и высокой рентабельности птицехозяйств!

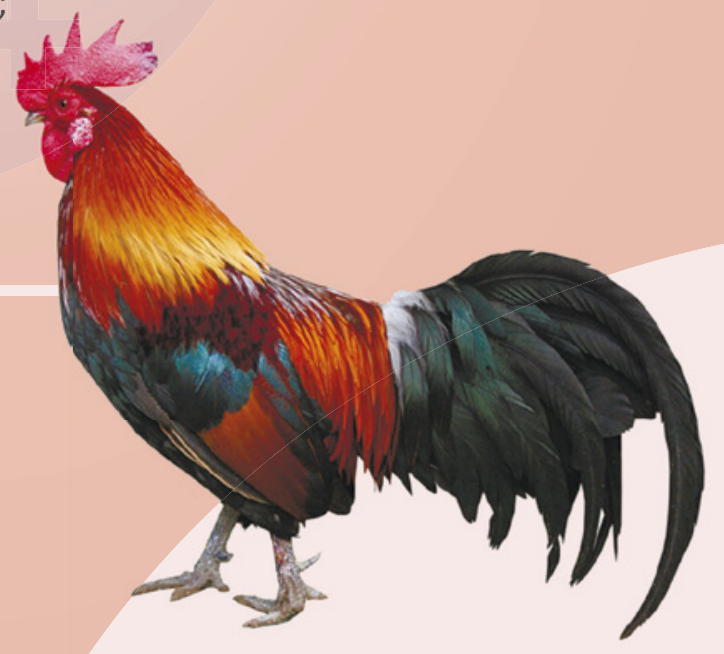




\section{РОССИЙСКАЯ АКАДЕМИЯ СЕЛЬСКОХОЗЯЙСТВЕННЫХ НАУК \\ ГОСУДАРСТВЕННОЕ НАУЧНОЕ УЧРЕЖДЕНИЕ \\ ВСЕРОССИЙСКИЙ НАУЧНО-ИССЛЕДОВАТЕЛЬСКИЙ \\ ВЕТЕРИНАРНЫЙ ИНСТИТУТ ПТИЦЕВОДСТВА}

198412,г.Санкт-Петербург,Ломоносов,ул. Черникова, д.48

т/\$ 8 (812) 372-54-80, 372-54-81, e. mail: vnivip@yandex.ru, www.vnivip.com

\section{ВАКЦИНА ПРОТИВ ПАРВОВИРУСНОЙ ИНФЕКЦИИ ГУСЕЙ ИНАКТИВИРОВАННАЯ ЭМУЛЬГИРОВАННАЯ}

Вакцина предназначена для специфической профилактики парвовирусной инфекции (вирусного энтерита, болезни Держи) гусей в стационарных неблагополучных хозяйствах и в случае острой вспышки болезни.

Методом клонирования эпизоотических штаммов парвовируса селекционирован апатогенный, иммуногенный «клон 6» штамма П-75, обладающий высокой степенью репродукции в культуре клеток, выраженной антигенностью и иммуногенностью.

Вакцинируют клинически здоровых гусей не позднее, чем за один месяц до начала яйцекладки. Иммунный ответ формируется через 14-21 сутки после вакцинации и сохраняется не менее 12 месяцев.

При двукратной вакцинации родительского стада гусей перед яйцекладкой у потомства развивается стойкий иммунитет на весь восприимчивый период.

По внешнему виду вакцина представляет собой однородную эмульсию белого или розового цвета. Лекарственная форма-эмульсия для инъекций.

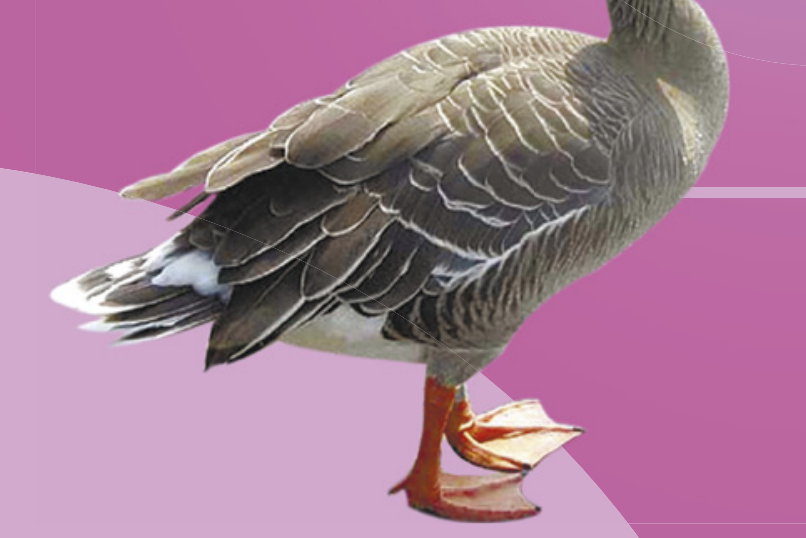

Вакцина ВНИВИП - гарант эпизоотического благополучия и высокой рентабельности птицехозяйства!

Наш опыт и компетентность-Ваш успех! 


\section{РОССИЙСКАЯ АКАДЕМИЯ СЕЛЬСКОХОЗЯЙСТВЕННЫХ НАУК \\ ГОСУДАРСТВЕННОЕ НАУЧНОЕ УЧРЕЖДЕНИЕ \\ ВСЕРОССИЙСКИЙ НАУЧНО-ИССЛЕДОВАТЕЛЬСКИЙ \\ ВЕТЕРИНАРНЫЙ ИНСТИТУТ ПТИЦЕВОДСТВА}

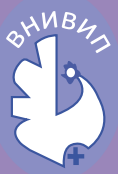

198412,г.Санкт-Петербург,Ломоносов,ул.Черникова, д.48 т/ф 8 (812) 372-54-80, 372-54-81, e. mail: vnivip@yandex.ru, www.vnivip.com

\section{ВИРУСВАКЦИНА \\ СУХАЯ КУЛЬТУРАЛЬНАЯ ВНИВИП ПРОТИВ ВИРУСНОГО ЭНТЕРИТА ГУСЕЙ}

Вакцина предназначена для специфической профилактики вирусного энтерита (парвовирусной инфекции, болезни Держи) гусей. Оптимальный состав вакцины позволяет достичь у привитой птицы необходимого защитного уровня антител для передачи материнского иммунитета на весь репродуктивный

Вакцину изготавливают на основе ареактогенного клона парвовируса гусей ( патент РФ № 215834).

Вакцину применяют в неблагополучных гусеводческих комплексах, фермерских и подсобных хозяйствах для вакцинации гусят суточного возраста и гусей родительского стада.

Преимущества вакцины:

- генетическая однородность;

- высокая безопасность, ареактогенность и ареверсибельность;

- индуцирует у привитой птицы формирование напряженного иммунитета на весь репродуктивный период;

- способствует повышению оплодотворяемости, выводимости и сохранности гусят до 95-98\%;

- обеспечивает получение здорового потомства и эффективное использование кормов;

- повышает рентабельность предприятия.

Вакцины ГНУ ВНИВИП -

гарант эпизоотического благополучия и высокой рентабельности птицехозяйств ! 
198412,г.Санкт-Петербург,Ломоносов,ул.Черникова, д.48 т/\$ 8 (812) 372-54-80, 372-54-81, e. mail: vnivip@yandex.ru, www.vnivip.com

\section{ВАКЦИНА ПРОТИВ ПАСТЕРЕЛЛЕЗА ПТИЦ ИНАКТИВИРОВАННАЯ СОРБИРОВАННАЯ}

Вакцину применяют с профилактической целью в неблагополучных или угрожаемых по пастереллезу птицехозяйствах и индивидуальном секторе.

Вакцинируют только клинически здоровых кур, индеек, гусей, начиная с 30 суточного возраста, а уток с 15 суточного возраста - однократно, внутримышечно. Специфический иммунитет формируется на 21 сутки после вакцинации.

Вакцина успешно применяется с 1989 года в птицехозяйствах Российской Федерации и стран СНГ.

Иммунизация обеспечивает эпизоотическое оздоровление хозяйства от пастереллеза, повышает рентабельность производства за счет увеличения показателей сохранности птицы и получения потомства с высокой продуктивностью.

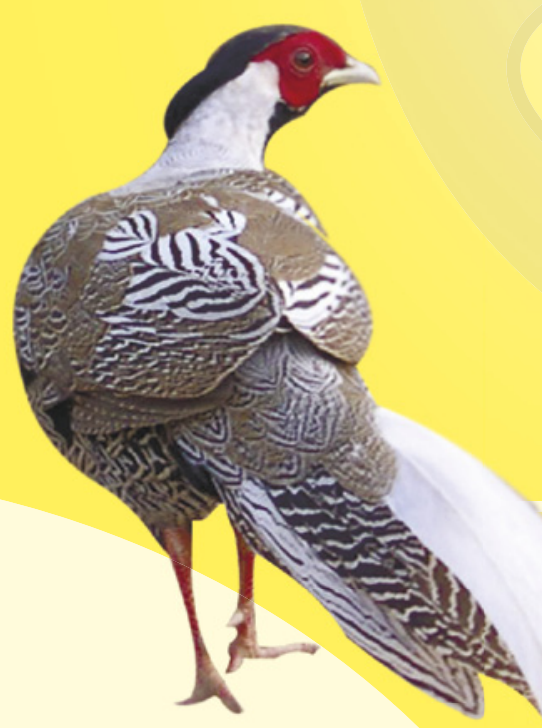

Вакцина ВНИВИП - гарант эпизоотического благополучия и высокой рентабельности птицехозяйства! Наш опыт и компетентность-Ваш успех! 
РОССИЙСКАЯ АКАДЕМИЯ СЕЛЬСКОХОЗЯЙСТВЕННЫХ НАУК

ГОСУДАРСТВЕННОЕ НАУЧНОЕ УЧРЕЖДЕНИЕ

ВСЕРОССИЙСКИЙ НАУЧНО-ИССЛЕДОВАТЕЛЬСКИЙ

ВЕТЕРИНАРНЫЙ ИНСТИТУТ ПТИЦЕВОДСТВА

198412,г.Санкт-Петербург,Ломоносов,ул.Черникова, д.48 т/\$ 8 (812) 372-54-80, 372-54-81, e. mail: vnivip@yandex.ru, www.vnivip.com

\section{ВИРУСВАКЦИНА ЖИВАЯ СУХАЯ ПРОТИВ НЬЮКАСЛСКОЙ БОЛЕЗНИ ИЗ ЛЕНТОГЕННЫХ ШТАММОВ}

Вирусвакцина предназначена для профилактии ньюкаслской болезни (НБ) птиц в племенных и товарных птицеводческих хозяйствах различного направления выращивания. Вакцинации подлежит клинически здоровая птица любого возраста в зависимости от эпизоотической ситуации.

По внешнему виду вирусвакцина представляет собой однородную пористую массу от серовато-желтого до коричневого цвета, легко растворимую в воде без образования осадка и хлопьев.

Вирусвакцину применяют интраназально (окулярно), энтерально, аэрозольно и методом крупнокапельного распыления (спрей-метод), начиная с суточного возраста. Иммунитет к вирусу НБ формируется через 12-14 суток и сохраняется в течение 3 месяцев.

Преимущества вирусвакцины:

- высокая безопасность, ареактогенность ;
- способствует повышению сохранности до 95-98 \%;
- повышает рентабельность работы предприятия;
- не вызывает поствакцинальных реакций;.

Срок годности - 18 месяцев со дня изготовления.

Вакцины ГНУ ВНИВИП -

гарант эпизоотического благополучия

и высокой рентабельности

птицехозяйств ! 


\section{ГНУ ВНИВИП РОССЕЛЬХОЗАКАДЕМИИ ПРОВОДИТ ДИАГНОСТИЧЕСКИЕ ИССЛЕДОВАНИЯ}

- Эпизоотологическое обследование птицеводческих хозяйств

- Вирусологические (постановка реакции нейтрализации (РН), выделение вирусов с использованием СПФ-куриных эмбрионов, клеточных культур)

- Микробиологические

- Серологические (РТГА, РДП, ИФА)

- Паразитологические

- Молекулярно-биологические (полимеразно-цепная реакция (ПЦР) и геномное секвенирование)

- Патоморфологические

- Биохимические исследования крови

- Определение токсичности различных веществ

На основе проведенных исследований сотрудники института дадут рекомендации по проведению ветеринарных мероприятий

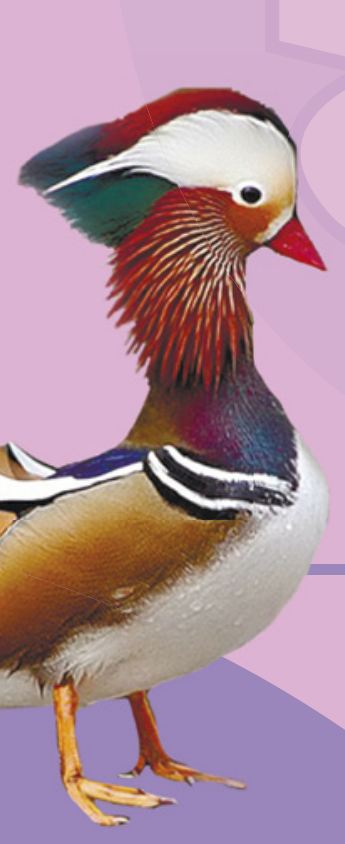

ГНУ ВНИВИп Россельхозакадемии осуществляет:

- обучение в аспирантуре (очная и заочная формы обучения)

- проведение курсов повышения квалификации ветеринарных врачей птицеводческих хозяйств - стажировку ветеринарных врачей по вопросам лабораторной диагностики 


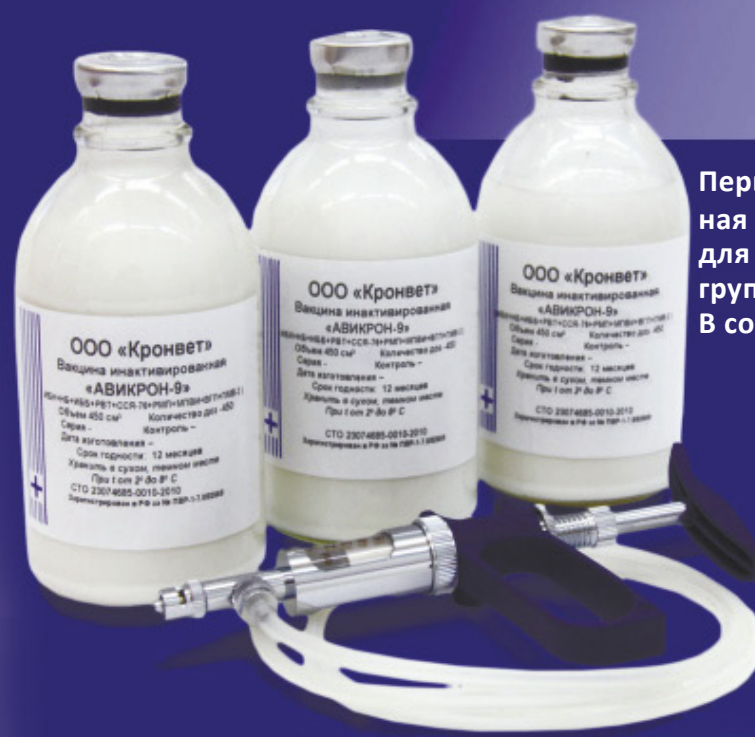

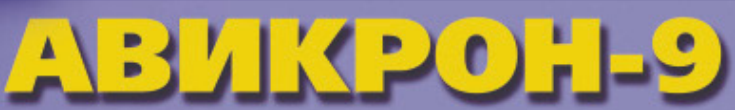
СЕРИЯ ИНАКТИВИРОВАННЫХ ВАКЦИН

Первая в мире ассоциированная инактивированная вакцина "Авикрон-9»

для иммунизации птицы всех возрастных групп, в том числе цыплят суточного возраста.

В состав вакцины входят антигены вирусов:

- инфекционного бронхита кур (ИБК)

- ньюкаслской болезни (НБ)

- инфекционной бурсальной болезни (ИББ)

- реовирусного теносиновита кур (РВТ)

- синдрома снижения яйценоскости (ССя-76)

- респираторного микоплазмоза птиц (РМП)

- метапневмовирусной инфекции птиц

(МПвИ)

- вирусного гидроперикардита кур (ВГП)

- парамиксовирусной инфекции птиц 2

серотипа (ПМВ-2)

В зависимости от эпизоотической ситуации в птицеводческом хозяйстве вакцина может содержать от одного до девяти антигенов в любом сочетании.

Применение вакцины обеспечивает:

- эффективность на любом эпизоотическом фоне

- формирование однородного длительного иммунитета (до 1,5 лет)

- повышение эффективности схем специфической профилактики

- уменьшение количества вакцинаций

- снижение трудоемкости ветеринарных обработок

- снижение количества случаев секундарных инфекций, вплоть до полного их отсутствия

- существенное уменьшение потребления антибиотиков

и других антибактериальных средств

- эпизоотическое благополучие птицехозяйства

- получение безопасной и качественной продукции птицеводства

- повышение рентабельности предприятий за счет улучшения производственных показателей
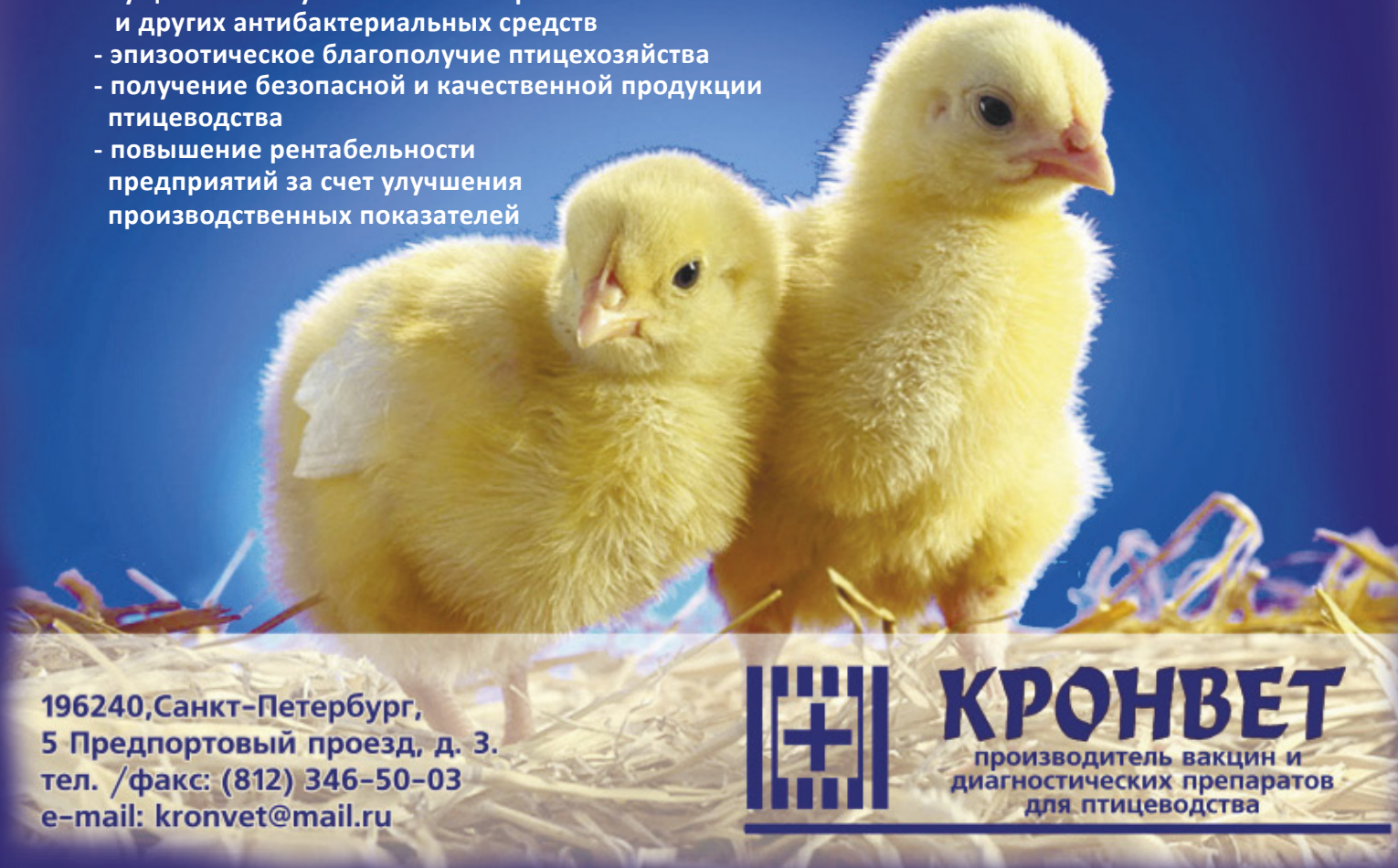
РОССИЙСКАЯ АКАДЕМИЯ СЕЛЬСКОХОЗЯЙСТВЕННЫХ НАУК ГОСУДАРСТВЕННОЕ НАУЧНОЕ УЧРЕЖДЕНИЕ ВСЕРОССИЙСКИЙ НАУЧНО-ИССЛЕДОВАТЕЛЬСКИЙ ВЕТЕРИНАРНЫЙ ИНСТИТУТ ПТИЦЕВОДСТВА

198412,г.Санкт-Петербург,Ломоносов,ул.Черникова, д.48 т/\$ 8 (812) 372-54-80, 372-54-81, e. mail: vnivip@yandex.ru, www.vnivip.com

\section{НАБОР ДЛЯ ВЫЯВЛЕНИЯ АНТИТЕЛ К ВИРУСУ ЭНТЕРИТА В СЫВОРОТКАХ КРОВИ ГУСЕЙ МЕТОДОМ ИММУНОФЕРМЕНТНОГО АНАЛИЗА} СТО 00495674-0009-2010 СОСТАВ НАБОРА:

Положительная сыворотка крови гусей к вирусу энтерита - 1 ампула Отрицательная сыворотка крови гусей - 1 ампула Антивидовой конъюгат против Ig G гусей - 1 ампула Антиген вируса энтерита гусей адсорбированный в лунках планшета - 2шт.

Буферный раствор (концентрированный) - 1 флакон Детергент твин-20 - 1 флакон

Набор солей для приготовления субстратного буфера - 1флакон Субстрат - ортофенилендиамин - 1 флакон

Гидроперит - 1 таблетка Натрий хлористый - 1 флакон

Хранить в сухом темном месте при температуре от 2ㅇ до 8을 Набор предназначен для:

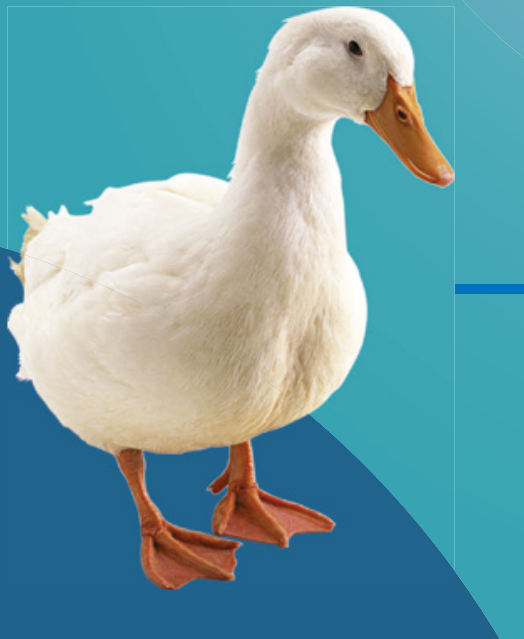

серологического контроля за распространением ВЭГ в популяциях гусей; оценки эффективности иммунизации поголовья против данного заболевания; ретроспективной диагностики ВЭГ у гусей 
ISBN 978-5-86983-522-2

NIIIIIII

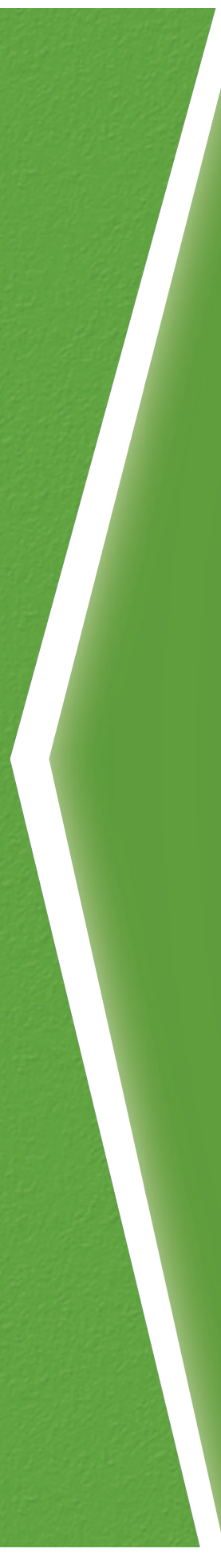

